\author{
В.Е. Дьяков
}

\title{
ОСНОВЫ ЦЕНТРОБЕЖНОЙ ФИЛЬТРАЦИИ РАСПЛАВОВ ОТХОДОВ ЦИНКА ПОГРУЖАЕМЫМ ФИЛЬТРОМ
}

Монография 
УДК 669

ББК 34.33

Д93

\section{Рецензенты:}

Юхин Ю.М. - доктор химических наук, ФГБУН «Институт химии твёрдого тела и механохимии» $\mathrm{CO}$ РАН;

Олейникова Н.В. - доктор технических наук, кафедра цветной металлургии, ФГАОУ ВО СФУ, Красноярск.

Дьяков В.Е.

Основы центробежной фильтрации расплавов отходов цинка погружаемым фильтром: монография. - М.: Издательский дом Академии Естествознания, 2019. - 102 с.

\section{ISBN 978-5-91327-591-2 \\ DOI 10.17513/np.366}

Монография посвящена разработке технологии фильтрация расплавленных металлов погружаемым фильтром. В монографии описан принцип действия работы моделей лабораторных и промышленных центрифуг и обосновано поведение твердых частиц в расплаве внутри фильтра под действием центробежных сил. Описанием физических основ взаимодействия фильтра с расплавом доказан эффект возникновения всасывания и циркуляция расплава через фильтр. Исследовано влияние скорости вращения фильтра в расплаве и глубины погружения его в расплав как факторы влияющие на скорость наполнения фильтра осадком и на общую производительность фильтрации. Обработкой экспериментов показано влияние скорости вращения фильтра над расплавом на степень очистки осадка от свободного жидкого цинка. Приведены результаты исследований влияния температуры и содержания алюминия на удаление железа из гартцинка минимальным выходом цинка в отходы. Экспериментально показана эффективность очистки цинка от железа и приведена кинетика удаления железа из гартцинка и в виде фаз железа с алюминием. Описана экстракция железа из расплава в соединении с алюминием. Методом электронной спектроскопии растровым электронным микроскопом с рентгеновским микроанализатором показаны фазы железа, выделение в дроссы и оценено распределение дисперсных фаз. Расчетом толщины пленки цинка на кристаллах железа с алюминием и толщины пленки кислорода на поверхности кристаллов показано влияние на снижение выхода цинка в дроссы. Приведено сопоставление результатов промышленных плавок с гартцинком, полученных из разных металлургических заводов. Сделан обзор конструкций центрифуг для удаления железа непосредственно из ванн цинкования.

Ключевые слова: расплавы, металлы, фильтрация, центрифуги, цинк, фазы примесей.

\section{ISBN 978-5-91327-591-2}

(С) Дьяков В.Е., 2019

(с) ИД «Академия Естествознания»

(с) $\mathrm{AHO} \mathrm{«Академия} \mathrm{Естествознания»}$ 


\section{ПРЕДИСДОВИЕ}

Успехи в разработки и освоение рафинирования олова центробежной фильтрацией на Новосибирском оловянном комбинате под руководством Сутурина С.Н. создали интерес в распространении способа и аппарата для регенерации цветных металлов из отходов сплавов.

Научный сотрудник СКБ ГИТ АН СО РАН. Долгов А.В. при координации с институтами гидродинамики СО РАН, Гидроцветмет создал серию аппаратов центробежной фильтрации для олова и свинца. Это стимулировало к расширению области их применения в регенерации цинка из отходов металлургических заводов, использующих горячее цинкование.

Благодаря поддержке лабораторий институтов ИНХ СО РАН, ИХТТИМС СО РАН, института геологии СО РАН исследования проведены с использованием инструментальных методов.

Исследования проведены коллективом опытного цеха Новосибирского оловянного комбината Двуреченской Е.Д., Далбеева Г.В., Быковой Н.Л. под руководством Сутурина С.Н. и обобщены лабораторией института ЦНИИОлова.

Творческая инициатива начальника цеха Опутина В.Г. и главного инженера Дугельного А.П. обеспечили полупромышленные испытания фильтрации гартцинка по запросам ряда сталепрокатных заводов.

Автор выражает благодарность коллективу химико-металлургическому отделению опытного цеха Новосибирского оловянного комбината выполнившие опытные работы и контроль за промышленными испытаниями.

Особую благодарность Варнек В.А., Перевозкину В.Ю., научным сотрудникам ИНХ СО РАН за помощь в исследовании фазовых форм дроссов методом РСМА и мессбауэровской спектроскопией, и Аввакумову Е.Г. за содействие рентгенофазового анализа дроссов. 


\section{ВВЕДЕНИЕ}

Разработка и отладка центробежного аппарата рафинирования олова до выпуска промышленных партий центрифуг и использования их в металлургии олова создала возможность расширения перспектив использования центробежных аппаратов фильтрации свинца [1].

В монографии обобщаем результаты использования центробежной фильтрации для переработки отходов легкоплавких цветных металлов, таких как гартцинк.

Цинк в объеме $25 \%$ от мирового потребления используют для защиты стального листа, труб, конструкций от атмосферной коррозии. Одним из способов создания цинкового покрытия на стальных поверхностях является горячего цинкования металлических поверхностей на ваннах цинкования. Во избежание образования брака цинкового покрытия из-за накопления железа проводится очистка ванны цинкования от гартцинка.

Отходы из ванн цинкования, так называемый гартцинк, содержит 91-95\% цинка, 2-4,3\% железа [2]. Для исследования перспектив использования центробежной фильтрации отходов цинка использовались лабораторные центрифуги, применяемые для исследования рафинирования олова и свинца. 


\section{Гдава 1. МЕТОДИКА ИССДЕДОВАНИЯ ЦЕНТРОБЕЖНОЙ ФИЯЬТРАЦИИ РАСПИАВОВ ПОГРУЖАЕМЫМ ФИЛЬТРОМ}

Отдельные опыты по рафинированию гартцинка от железа проводили на лабораторной центрифуге (рис. 1) с погружаемым фильтром, ранее используемой для разработки фильтрации олова [3].

Центрифуга (рис. 1) представляет собой фильтр из двух конусообразных тарелей 2, 3, сжатых большими основаниями с образованием фильтрующей щели 4. Основание конуса у ротора снабжено заборными окнами 5. С помощью привода 8 фильтр 2 погружается в расплав и приводится во вращение. Во время вращения фильтра в расплаве через заборные окна 5 расплав всасывается во внутреннюю полость между тарелями и под действием центробежных сил жидкая фаза (очищенный металл) продавливается через фильтрующую щель 4, образованную торцами боль-

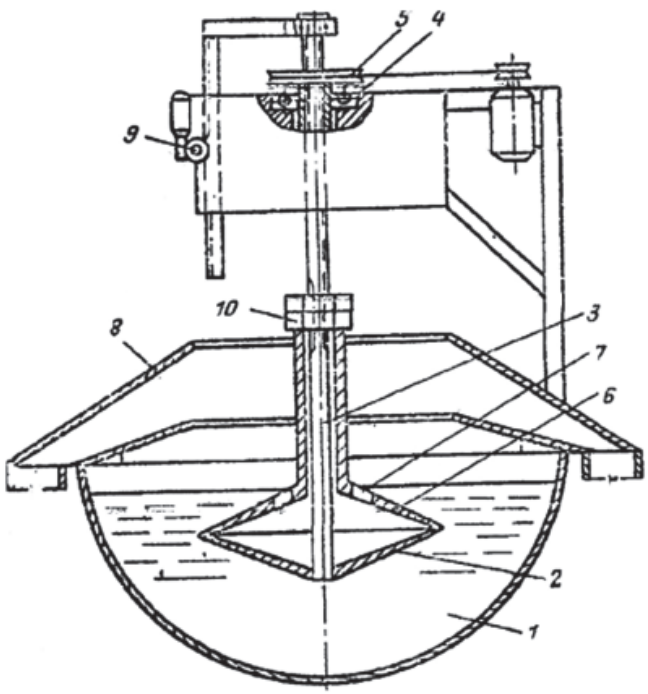

Рис. 1. Центрифуга лабораторная с погружаемым фильтром.

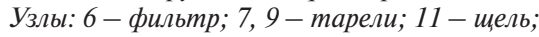
12 - окно забора ших оснований тарелей и выбрасывается в общий расплав в котле. Твердые кристаллы примесей в виде дроссов остаются в полости фильтра у кромки фильтрующей щели 4. По истечении заданного времени вращающийся ротор с фильтром не прекращая вращения поднимался над поверхностью расплавом (рис. 2) [4] рафинируемого металла, выбрасывая остатки жидкой фазы через фильтрующую щель. 


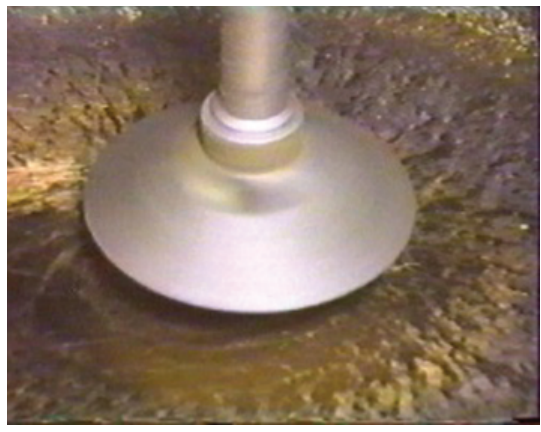

Рис. 2. Фильтр лабораторной центрифуги на отжиме расплава

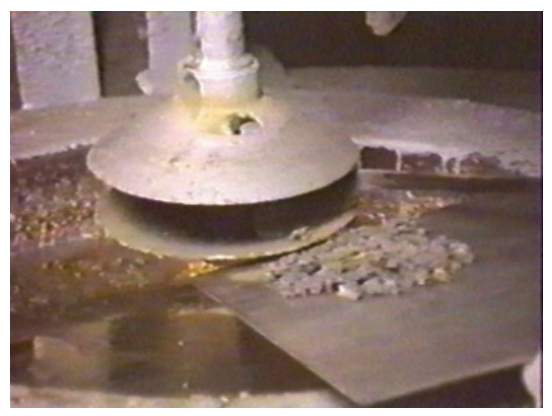

Рис. 3. Тарели фильтра на ручной разгрузке

После «осушки» осадка стопор фиксации тарелей ослаблялся и осадок выбрасывался под действием центробежных сил. В отдельных опытах отбирались пробы брызг металла из фильтра в процессе осушки дроссов в поднятом над расплавом положении вращающегося фильтра. Периодически в опытах съемы разгружали вручную (рис. 3) после остановки вращения для взвешивания.

В дальнейшем исследования проводились на лабораторной центрифуге рис. 4.

Серию укрупненных опытов по рафинированию гартцинка от железа проводили центробежной фильтрацией на центрифуге модели ЦП-200 (рис. 5) [6]; с автоматической регулировкой циклов погружения фильтра в расплав.

В верхней части ротор 1 снабжен пружиной 6 для сжатия тарелей и укреплен на траверсе 7 , соединенной с приводами вращения 8 и подъема ротора 9. Размер фильтрующей щели 4 регулируется сжатием пружины 6 и обычно составляет 0,1 мм.

Центрифуга устанавливалась на чугунный котел емкостью 40 л, диаметром 400 мм, глубиной 400 мм. Котел снабжен электрообогревом с регулятором температуры ТРМ201 с термопарой ТХА. В котел загружались по весу слитки гартцинка, расплавлялись, расплав перемешивался пропеллерной мешалкой и устанавливалась заданная температура и проводилось отделение твердых дроссов из расплава фильтрации.

Для установки необходимой глубины погружения фильтра в расплав, включения двигателя вращения установлен нижний концевой переключатель. По истечении задаваемой через реле длительностью вращения фильтр с ротором поднимался из расплава.

При подъеме до установленного среднего концевого переключателя «уровень отжима» 13 (рис. 5) процессор переключает привод 
на увеличение числа оборотов на задаваемое время и происходит до удаление остатков жидкого металла оставшегося между кристаллами дроссов из полости фильтра, т. е. происходит «досушка» осадка от жидкой фазы. Брызги жидкого расплава стекают по конусу отбойника в котел.

После осушки осадка в течение 15-30 с, задаваемое процессором время в интервале 30-60 с, вращающийся фильтр поднимается до зоны выброса дроссов «уровня 14 скребкового транспортера 10» на рис. 5 , где

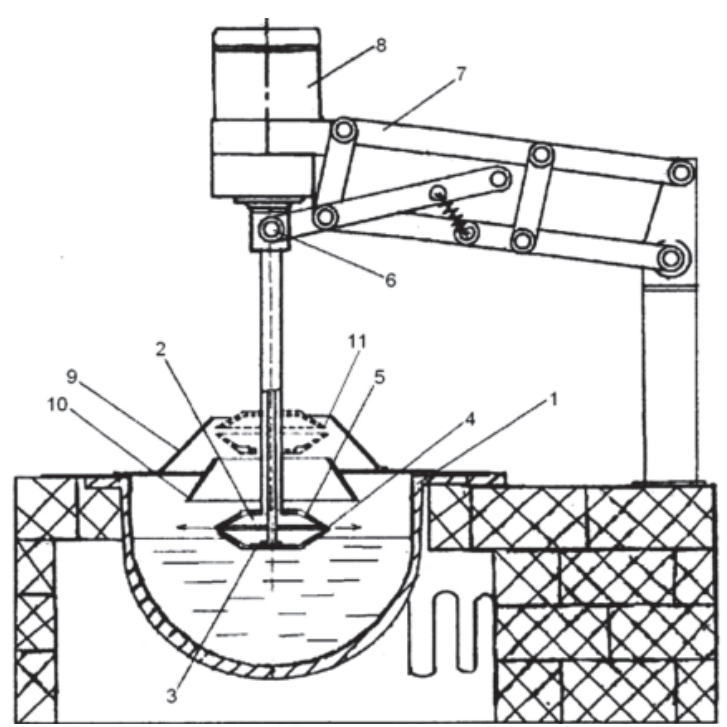

Рис. 4. Лабораторная центрифуга ЦП 100 [5]:

1 - котел 2- верхняя тарель; 3 - нижняя тарель; 4 - фильтрующая щель; 5- заборные окна;

6 - стопор раскрытия тарелей и разгрузки осадка из фильтра; 7 -механизм подъема фильтра; 8-двигатель вращения фильтра; 9 - сбемный конус сбора дроссов; 10 - съемный конус сбора брызг из фильтра;

11 - уровень подъема фильтра для раскрытия тарелей и разгрузки осадка

с помощью сжатия

пружины 6 тарели раздвигаются и осадок под действием центробежных сил выбрасывается из полости раскрывшихся тарелей фильтра на движущийся скребковый транспортер 10, который выгружает их в тару. Количество погружений фильтра на заполнение осадком фиксировалось по счетчику [6].

Разгруженный дросс взвешивался и после проборазделки на прибоpe Fritsch - проба анализировалась атомно адсобционным методом на атомно-эмиссионном спектрометре с индуктивно связанной плазмой IRIS Intrepid компании INTERTECH Corporation.

При удалении фазы твердой примеси из расплава можно выделить фазы: кинетика образования твердых соединений кристаллов из расплава; заполнении полости фильтра твердый осадок из расплава и отделении жидкого расплава из дроссов. 


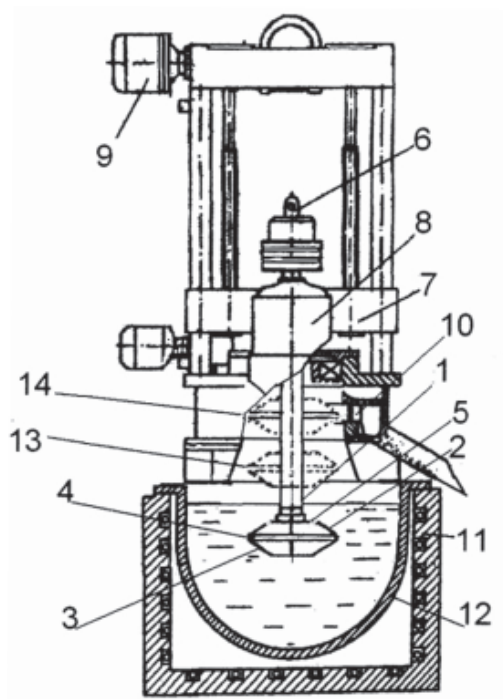

Рис. 5. Аппарат погружной центрифуги ЦП-200:

1 - ротор; 2 - фильтр тарельчатый;

3-тарели; 4-фильтрующая щель;

5 - заборные окна; 6 - пружина;

7 - траверса подъема ротора; 8 - привод вращения; 9 - привод подъема ротора; 10 - скребковый транспортер, 11 - печь; 12 - котел; 13 - положение фильтра при отжиме; 14 - положение фильтра при выбросе дроссов

В любой операции фильтрации расплава погружаемым фильтром фиксируются циклы погружения фильтра, вращения фильтра для сбора осадка, подъем фильтра из расплава, отжатия осадка от жидкой фазы, выброс осадка и повторное погружение.

В зависимости от условий плавки длительность циклов и скорость вращения может заранее устанавливаться.

Длительность вращения фильтра в погруженном состоянии и длительность вращения фильтра на отжим задается реле времени.

Степень очистки расплава от твердых кристаллов примесей зависит от длительности вращения фильтра в погруженном в расплав состоянии для полного заполнения полости фильтра и количества погружений.

В табл. 1 показана длительность стадий одного цикла фильтрации погружаемым фильтром с указанием положения фильтра.

От степени заполнения полости фильтра осадком примесей зависит общая длительность процесса очистки партии металла от примесей и в целом производительность центробежной фильтрации. Низкая производительность заполнения полости фильтра при заданной длительности вращения увеличивает количество циклов с не заполненной полостью фильтра, что в целом снижает производительность центрифуги. Высокая производительность заполнения полости фильтра при заранее заданной высокой длительности вращения фильтра в расплаве увеличивает излишнее количество циклов с полной загрузкой фильтра, что в целом снижает производительность центрифуги. Для пояснения характеристики положения фильтра в моменты цикла фильтрации на рис. 6 показана циклограмма работы фильтра и длительность (в с) в каждом положении. 
Таблица 1

Длительность операций цикла фильтрации погружным фильтром

\begin{tabular}{|c|c|c|c|c|c|c|}
\hline \multirow{3}{*}{ Операция } & \multicolumn{4}{|c|}{ ЦП-200 } & \multicolumn{2}{|c|}{ ПАВФС-650 } \\
\hline & \multirow{2}{*}{$\begin{array}{c}\text { дли- } \\
\text { тель- } \\
\text { ность, с }\end{array}$} & \multirow{2}{*}{$\begin{array}{c}\text { поло- } \\
\text { жение } \\
\text { филь- } \\
\text { тра, см }\end{array}$} & \multicolumn{2}{|c|}{$\begin{array}{c}\text { момент от } \\
\text { начала }\end{array}$} & \multirow{2}{*}{$\begin{array}{c}\text { дли- } \\
\text { тель- } \\
\text { ность, с }\end{array}$} & \multirow{2}{*}{$\begin{array}{c}\text { поло- } \\
\text { жение } \\
\text { фильтра, } \\
\text { см }\end{array}$} \\
\hline & & & $\mathrm{c}$ & $\mathrm{cm}$ & & \\
\hline Уровень металла & & $-7-22$ & & -10 & & -32 \\
\hline Исходное положение фильтра & 0 & 17 & 0 & 17 & 0 & 40 \\
\hline Погружение фильтра в расплав & 120 & $-9-22$ & 120 & -15 & 30 & $-44-80$ \\
\hline Наполнение фильтра вращением & $30-420$ & $-9-22$ & 240 & -15 & $30-180$ & $-44-80$ \\
\hline Подъем фильтра на отжим & 60 & 6 & 300 & 6 & 30 & -20 \\
\hline Очистка дроссов от расплава & $15-120$ & 6 & 360 & 6 & $30-180$ & -20 \\
\hline Подъем фильтра для разгрузки & 60 & 14 & 420 & 14 & 30 & +40 \\
\hline Разгрузка дроссов & 5 & 14 & 425 & 14 & 5 & +40 \\
\hline Исходное положение фильтра & 0 & 17 & 0 & & 0 & 40 \\
\hline Цикл & \multicolumn{2}{|c|}{$290-765$} & \multicolumn{2}{|c|}{425} & \multicolumn{2}{|c|}{$155-455$} \\
\hline
\end{tabular}

Работа погружаемого фильтра поясняется циклограммой, характеризующей высоту положения фильтра в каждый момент времени (в с).

Количество погружений фильтра на заполнение осадком фиксировалось по счетчику. Суммарное время циклов вращения фильтра в погруженном состоянии до окончания очистки заданного веса плавки обозначается $B_{\phi}($ в с $)$.

Суммарная длительность циклов, включающая длительность вращения в расплаве, длительность подъема фильтра над расплавом, длительность отжатия жидкого расплава из осадка и длительность опускания фильтра вновь в расплав, обозначается Д - длительность цикла.

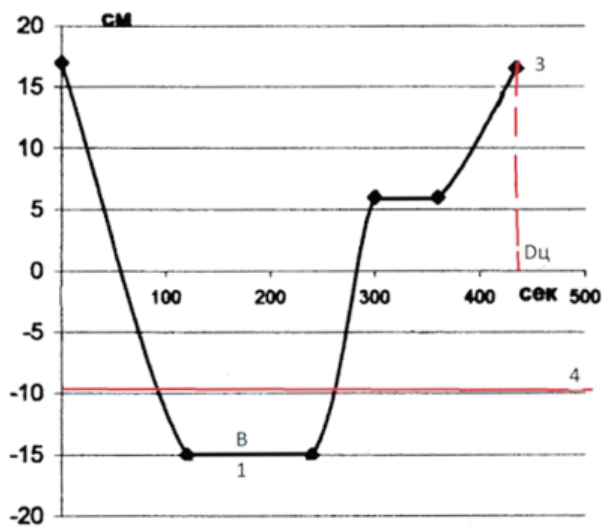

Рис. 6. Циклограмма работы фильтра: по абсииссе - момент от начала, $c$; по ординате - положение фильтра, см; 1 - погружение фильтра для его наполнения; $B i, c ; 2$ - подъем фильтра для очистки дроссов от жидкого цинка; 3 - верхняя точка положения фильтра в момент разгрузки, $D_{u}-$ длительность цикла; 4-уровень расплава в котле, в см, от основания центрифуги на котле 


\section{Гдава 2. ФИЗИЧЕСКИЕ ОСНОВЫ ЦЕНТРОБЕЖНОЙ ФИЛЬТРАЦИИ ПОГРУЖАЕМЫМ ФИЯЬТРОМ}

В описании методики исследования центробежной фильтрации показано, что фильтр состоит из двух конусообразных дисков сжатых большими основаниями с образованием щели между ними и снабженных окнами у малых оснований конусов. Фильтр погружается в суспензию металлического расплава и приводится во вращение. При этом происходят процессы:

- Перемешивание расплава металла с твердыми частицами примесей.

- Всасывание расплава в полость фильтра через заборные окна у основания конуса и выброс плава через щель на периферии большого основания конуса.

- Воздействие центробежных сил на твердые частицы в слое расплава внутри полости фильтра.

- Продавливание жидкости через поры твердого осадка под воздействием центробежной силы.

Рассмотрим указанные факторы используя исходные данные из табл. 2.

Таблица 2

Исходные данные для расчета взаимодействия фильтра

с расплавом гартцинка

\begin{tabular}{|c|c|c|c|c|}
\hline $\begin{array}{c}\text { № } \\
\Pi / \Pi\end{array}$ & Параметр & Формула & $\begin{array}{c}\text { Размер- } \\
\text { ность }\end{array}$ & $\begin{array}{l}\text { Зна- } \\
\text { чение }\end{array}$ \\
\hline 1 & 2 & 3 & 4 & 5 \\
\hline \multicolumn{5}{|c|}{ Параметр фильтра: } \\
\hline 1 & Диаметр фильтра & $D$ & cM & 20 \\
\hline 2 & Радиус тарелей фильтра & $R$ & $\mathrm{~cm}$ & 10 \\
\hline 3 & Высота конуса тарели & $h$ & cM & 2,6 \\
\hline 4 & Радиус ротора нижней ступицы & $r_{1}$ & $\mathrm{~cm}$ & 2,5 \\
\hline 5 & Радиус заборных окон от оси & $r$ & $\mathrm{~cm}$ & 4 \\
\hline 6 & размер заборного окна $2 \times 1$, см & $1 \times 2$ & $\mathrm{~cm}$ & $1 \times 2$ \\
\hline 7 & Сечение заборных окон & $f_{\mathrm{o}}$ & $\mathrm{CM}^{2}$ & 4 \\
\hline 8 & Зазор щели фильтра & $t$ & MM & 0,5 \\
\hline
\end{tabular}


Окончание табл. 2

\begin{tabular}{|c|c|c|c|c|}
\hline 1 & 2 & 3 & 4 & 5 \\
\hline 9 & Площадь фильтрации & $F=p_{i} \cdot D \cdot t$ & $\mathrm{CM}^{2}$ & 3,14 \\
\hline \multirow[t]{2}{*}{10} & Объем полости фильтра & $v$ & $\mathrm{CM}^{3}$ & 739 \\
\hline & Параметры расплава [7] & & & \\
\hline 11 & Объем ванны расплава & $V$ & $\mathrm{M}^{3}$ & 0,03 \\
\hline 12 & Температура расплава, & $T$ & ${ }^{\circ} \mathrm{C}$ & 500 \\
\hline 13 & Плотность жидкого цинка & $\rho_{c}$ & $\Gamma / \mathrm{cM}^{3}$ & 6,02 \\
\hline 14 & Динамический К вязкости жидкого Zn & $\mu_{\mathrm{c}}$ & $\mathrm{H} \cdot \mathrm{c} / \mathrm{M}^{2}$ & 27,26 \\
\hline 15 & Плотность твердого Zn & & $\Gamma / \mathrm{cm}^{3}$ & 7,13 \\
\hline 16 & Плотность твердого Fe & & $\Gamma / \mathrm{cM}^{3}$ & 7,87 \\
\hline 17 & Плотность твердого Al & & $\Gamma / \mathrm{cm}^{3}$ & 2,7 \\
\hline 18 & Концентрация макс [Fe] & $\%$ & & 2,5 \\
\hline 19 & Доля $\mathrm{Fe}$ в $\mathrm{FeZn}_{7}$ & $\alpha$ & & 0,11 \\
\hline 20 & Доля $\mathrm{Fe}$ в $\mathrm{FeAl}_{3}$ & $\alpha$ & & 0,41 \\
\hline 21 & Концентрация фазы FeZn $\mathrm{Zn}_{10}$ & $\alpha$ & $\%$ & 31,7 \\
\hline 22 & Плотность твердой фазы $\mathrm{FeAl}_{3}$ & $\rho_{\mathrm{T}}$ & $\Gamma / \mathrm{CM}^{3}$ & 4,8 \\
\hline 23 & Плотность твердой фазы $\mathrm{FeZn}$. & $\rho_{\mathrm{T}}$ & $\Gamma / \mathrm{cm}^{3}$ & 7,2 \\
\hline 24 & Плотность суспензии расплава $-\rho_{\text {c }}$ & $\rho_{\mathrm{c}}=\rho_{\mathrm{T}} \cdot \alpha+\rho_{j}((1 \alpha)$ & $\Gamma / \mathrm{CM}^{3}$ & 5,7 \\
\hline 25 & Частицы, $d_{\mathrm{T}}<0,8 \cdot \delta$, мм & & мм & 0,4 \\
\hline 26 & Частицы, $d_{\mathrm{T}}>1,2 \cdot \delta$, мм & & MM & 0,6 \\
\hline 27 & Диаметр твердых частиц & $d_{\mathrm{T}}=1,5 \cdot t$ & MM & 0,75 \\
\hline 28 & Насыпной вес дроссов & & $\Gamma / \mathrm{cm}^{3}$ & 2,19 \\
\hline 29 & Скорость вращения фильтра в расплаве & $n_{3}$ & об/мин & 360 \\
\hline 30 & Угловая скорость фильтра в расплаве & $\omega=2 \cdot \pi \cdot n_{3}$ & рад/с & 37,7 \\
\hline 31 & Скорость вращения фильтра на отжиме & $N_{\mathrm{o}}$ & об/мин & 1500 \\
\hline 32 & Угловая скорость вращения в отжиме & $\omega=2 \pi \cdot n_{3}$ & рад/c & 157 \\
\hline
\end{tabular}

\section{1. Поведение вращающегося фильтра в расплаве}

Для получения однородных смесей жидких сред и интенсификации массообмена в химической аппаратуре применяются турбинные мешалки, создающие турбулентный режим течения жидкой среды. Турбинная мешалка (рис. 7) применяется для перемешивания кристаллических твердых частиц до образовании однородной суспензии в концентрации до $80 \%$ [8]. 


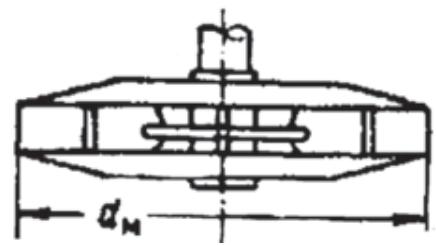

Рис. 7. Схема турбинной мешалки

Поэтому, расчеты турбинных мешалок используем с некоторым приближением для расчета закономерностей вращения фильтра в расплаве. Для расчета используем исходные данные в табл. 2. Скорость оседания твердых частиц в расплаве цинка можно ориентировочно определить по формуле:

$$
\omega_{\mathrm{oc}}=\frac{\left(\rho_{\mathrm{T}}-\rho_{\mathrm{c}}\right) \cdot g \cdot d_{\mathrm{T}}^{2}}{18 \cdot \mu_{\mathrm{c}}},
$$

где $\oplus_{\text {ос }}-$ скорость осаждения, м/с; $d_{\mathrm{T}}-$ диаметр твердой частицы, м; $\rho_{\text {т }}$ и $\rho_{\mathrm{c}}-$ плотность твердых частиц и среды, кг $/ \mathrm{M}^{3} ; g-$ ускорение силы

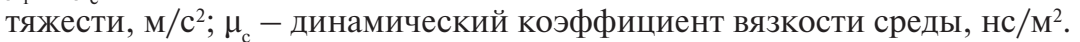

Расчет показал, что скорость осаждения твердых частиц соединения железа в расплаве цинка составляет менее 0,1 мм/с. Это объясняется малым различием плотности твердых частиц и жидкой фазы.

Твердые частицы в расплаве гартцинка при температуре фильтрации $T=450-480^{\circ} \mathrm{C}$ могут иметь максимальную концентрацию $[\mathrm{Fe}]=2,5 \%$ в виде соединения $\mathrm{FeZn}_{10}$ до содержания 31,7\% с плотностью твердой фазы 7,2 кг/дм³. В условиях удаления железа с алюминием в виде твердых частиц $\mathrm{Fe}_{2} \mathrm{~A}_{15}$ в концентрации 5,5\% с плотностью твердой фазы 5 кг/дм³.

Для предотвращения оседания осадка и равномерного распределения взвешенных частиц требуется обеспечивать скорость вращения не менее, чем определяется по формуле:

$$
n>20 \cdot w \cdot \frac{D}{d_{\mathrm{M}}^{2}},
$$

где $w$ - скорость осаждения частиц (в м/с); $d_{\text {м }}$ диаметр фильтра 200 мм.

По расчету для обеспечения однородности суспензии требуется скорость вращения фильтра более $0,01 \mathrm{c}^{-1}$. Практически используется скорость вращения $n=4 \mathrm{c}^{-1}$.

Длительность вращения фильтра-мешалки необходимая для выравнивания концентрации перемешиваемых веществ определяется [9] по формуле:

$$
\tau=\frac{5 V}{n \cdot d_{\mathrm{M}}^{3}}, \quad \mathrm{c},
$$

где $V$ - объем аппарата $\left(V=0,03 \mathrm{~m}^{3}\right) ; d_{\mathrm{m}}$ - диаметр фильтра 200 мм; $n$ - частота вращения (в $\left.\mathrm{c}^{-1}\right)$; По расчету для обеспечения однородной суспензии указанного расплава требуется $47 \mathrm{c}$. 
В период повышения или снижения скорости вращения фильтра достигается более равномерное распределение твердых частиц в расплаве. При остановки вращения на длительное время твердые кристаллы осаждаются и уплотняются в осадок. Для взмучивания уже осажденного осадка в котле необходимо более длительное 1020 мин вращение фильтра.

Расчеты показали, что небольшая разница в плотности твердой фазы и суспензии создали условия малой скорости осаждения твердой фазы требующей низкой скорости перемешивания для достижения равновесного состояния суспензии.

\section{2. Создание эффекта всасывания распдава в полость фильтра}

При вращении фильтра возникает центробежная сила G, которая воздействует на содержимое полости, заполненной суспензией твердых частиц в жидком расплаве. Центробежная сила $G($ в Н), воздействующая на содержимое полости при вращении фильтра определяется по уравнению:

$$
G_{1}=\frac{M \cdot n^{2}}{R}=M \cdot R \cdot \omega^{2},
$$

где $M$ - масса твердой фазы и жидкости в полости фильтра, кг; $n-$ частота вращения фильтра, $\mathrm{c}^{-1} ; R$ - радиус, расстояние частицы от оси вращения фильтра, м; $₫$ - угловая скорость, $\mathrm{c}^{-1}$.

При вращении фильтра наибольшая величина центробежная сила [10] действует на периферии фильтра, в щели зазора сжатых тарелей, где создается давление в щели фильтра $\Delta P_{\text {ц }}$ (в Па):

$$
\Delta P_{\text {ц }}=G / F,
$$

где $F-\left(\right.$ в $\left.^{2}\right)$ площадь фильтрации $F=\pi D \cdot t ; G$ - центробежная сила $($ в $\mathrm{H}) ; D$ - диаметр окружности фильтрующей щели равный диаметру фильтра, м; $t$ - зазор щели фильтрования (зазор между сжатыми тарелями), м (рис. 8).

У заборных окон, вблизи сочленения основания конуса фильтра и ротора центробежная сила создает несколько меньшее давление:

$$
\Delta P_{\mathrm{o}}=\frac{G_{\mathrm{o}}}{\pi r \cdot f_{\mathrm{o}}}
$$

где $G_{\mathrm{o}}$ - центробежная сила (в Н); 


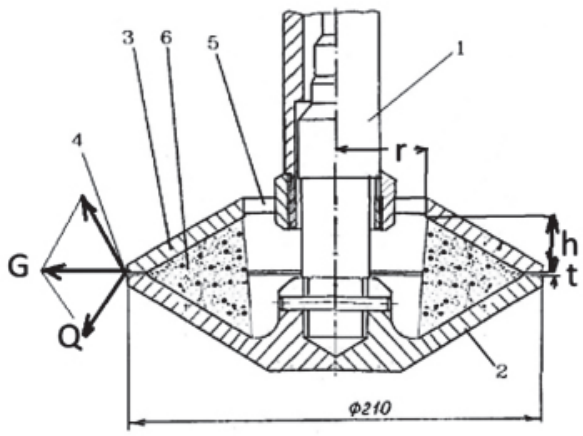

Рис. 8. Описание параметров фильтра.

Основные узлы: 1 - ротор; 2 - нижняя тарель; 3 - верхняя тарель; 4-фильтрующая щель $t$;

5 - заборные окна; 6 - осадок; $h$-высота конуса;

$r$ - радиус удаления заборного окна от оси;

$G$ - центробежная сила вынесенная от радиуса $r$;

$Q$ - нормальная составляющая центробежной силы прессования осадка

$$
G_{o}=\frac{M \cdot n^{2}}{R} ;
$$

$r-$ радиус - расстояние заборных окон от оси, м; $f_{\text {о }}$ - площадь (сечение) заборных окон. За счет разности давлений периферии и у оси $\left(\Delta P_{\text {ц }}-\Delta P_{\mathrm{o}}\right)$ создается поток расплава через всасывание в заборные окна и выброс через щель фильтра.

По мере циркуляции расплава через полость фильтр со скоростью 119,4см/с у фильтрующей щели накапливается осадок твердых примесей с производительностью 8,2 кг/с (п. 9,11 табл. 3).

В начальный момент, когда осадка нет у щели, скорость циркуляции максимальна. Причем, по мере увеличения толщины осадка у щели фильтра снижается площадь $F$ фильтрации. Поэтому, давление выброса расплава у щели снижается к нулю. Полость фильтра перестает наполняться и далее фильтр вращается вхолостую как мешалка. В табл. 3 приведены результаты расчетов.

Таблица 3

Результаты расчета взаимодействия фильтра с расплавом

\begin{tabular}{|c|c|c|c|c|}
\hline $\begin{array}{l}\text { № } \\
\Pi / \Pi\end{array}$ & Параметр & Формула & $\begin{array}{c}\text { Размер- } \\
\text { ность }\end{array}$ & $\begin{array}{l}\text { Зна- } \\
\text { чение }\end{array}$ \\
\hline 1 & 2 & 3 & 4 & 5 \\
\hline 1 & $\begin{array}{l}\text { Ускорение поля центробежных сил у филь- } \\
\text { трующей шели }\end{array}$ & $J=R \cdot \omega^{2}$ & $\mathrm{M} / \mathrm{c}^{2}$ & 142 \\
\hline 2 & Центробежная сила у фильтрующей щели & $G=M \cdot R \cdot \oplus^{2}$ & Кгс & 29,1 \\
\hline 3 & Исходная масса расплава в фильтре & $M$ & Кг & 5,1 \\
\hline 4 & Давление в щели фильтра: & $\Delta P_{\mathrm{L}}=\frac{G}{F}$ & ат & 88,4 \\
\hline 5 & $G_{\text {o }}$ - центробежная сила у окон & $G_{\mathrm{o}}=\frac{m \cdot n^{2}}{r}$ & Кгс & 0,3 \\
\hline
\end{tabular}


Окончание табл. 3

\begin{tabular}{|c|l|c|c|c|}
\hline 1 & \multicolumn{1}{|c|}{2} & 3 & 4 & 5 \\
\hline 6 & Масса 1 см услов слоя у заборн окон & $m$ & кг & 0,008 \\
\hline 7 & Давление в заборных окнах: & $\Delta P_{\mathrm{o}}=\frac{G_{\mathrm{o}}}{\pi r \cdot f_{o}}$ & ат. & 13,4 \\
\hline 8 & Разрежение в полости фильтра & $\Delta P_{\text {ц }}-\Delta P_{\mathrm{o}}$ & ат. & 75,3 \\
\hline 9 & $\begin{array}{l}\text { Скорость циркуляции расплава через филь- } \\
\text { трщель }\end{array}$ & $w=(2 \cdot G \cdot g)^{0,5}$ & дм/с & 74,4 \\
\hline 10 & Объемная скорость циркуляции $v=f \cdot w, \mathrm{~cm}^{3} / \mathrm{c}$ & $V=\mathrm{F} \cdot w$ & дм ${ }^{3} / \mathrm{c}$ & 2,3 \\
\hline 11 & Производительность наполнения фильтра & $Q_{\phi}=V \cdot \alpha \cdot \rho_{\mathrm{T}}$ & $\mathrm{\kappa г} / \mathrm{c}$ & 4,7 \\
\hline 12 & Сила выдавливания жидкой фазы из пор осад & $G_{\mathrm{o}}=\frac{m \cdot N_{\mathrm{o}}^{2}}{R}$ & $\mathrm{Kгс}$ & 0,48 \\
\hline 13 & Нормальная составляющая центросилы & $Q=G_{\phi} \cdot \sin 30$ & $\mathrm{\kappa гc}$ & 0,24 \\
\hline 14 & Сила выброса осадка из фильтра & $G_{\phi}=\frac{M \cdot N_{\mathrm{o}}^{2}}{R}$ & $\mathrm{\kappa гc}$ & 126,7 \\
\hline
\end{tabular}

Выбрасывание расплава из фильтрующей щели под действием центробежной силы создает в полости разряжение, влияющее на всасывание исходной суспензии. Возникает циркуляция расплава через полость фильтра, обеспечивает наполнение полости фильтра твердым осадком.

\section{3. Поведение твердой частицы \\ в поле центробежных сил в расплаве полости фильтра}

При ламинарном движении массы суспензии в полости фильтра твердые частицы перемещаются в расплаве под действием центробежной силы со скоростью, определяемой по формуле Стокса:

$$
W_{\text {u }}=\frac{\left(\rho_{\mathrm{T}}-\rho_{\mathrm{c}}\right) \cdot r \cdot d^{2} \cdot \omega^{2}}{18 \cdot \mu_{\mathrm{c}}},
$$

где $d_{\text {т }}$ - диаметр твердой частицы, м; примем несколько больше размера зазора щели $d_{\mathrm{T}}=0,3$ мм; $\rho_{\mathrm{T}}$ и $\rho_{\mathrm{c}}-$ плотность твердых частиц и среды, кг $/ \mathrm{M}^{3} ; \mu_{\mathrm{c}}-$ динамический коэффициент вязкости среды (расплава цинка), $\mu_{\mathrm{c}}=27,26 \mathrm{H} \cdot \mathrm{c} / \mathrm{M}^{2}$ при $500^{\circ} \mathrm{C}$ [7].

По расчету (п. 13 табл. 3.2) скорость смещения твердой фазы железа в суспензии полости фильтра составляет 0,0043-0,032 мм/с.

Поведение твердых кристаллов примесей в поле центробежных сил показан на примере поведения кристаллов AsMn в жидком олове. 

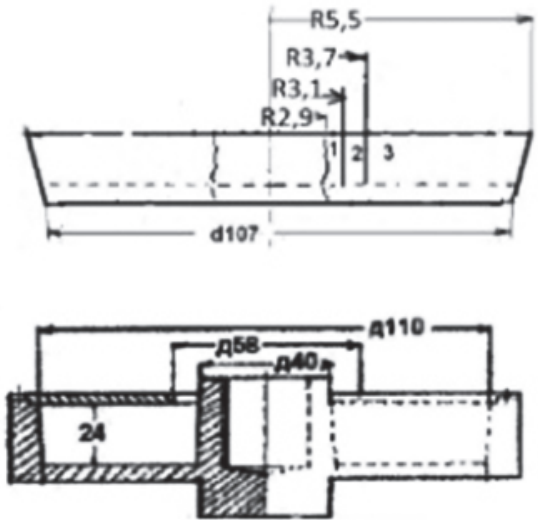

Рис. 9. Изложница слитка опыта затвердевания цинка в центробежном поле
Опыты проводили на лабораторной центрифуге с погружаемым фильтром. Вместо фильтра на вал ротора ввинчивался контейнер (рис. 9) как в работе [11.2] с кольцевой крышкой с образованием закрытой кольцевой полости.

Для рафинирования олова с содержанием $1,1 \%$ мышьяка при температуре $450^{\circ} \mathrm{C}$ в металл вмешивали лигатуру $\mathrm{Sn}-8 \% \mathrm{Mn}$ до содержания $1,5 \% \mathrm{Mn}$ в ванне олова. Контейнер погружался на 20 мин в расплавленное олово с температурой $450^{\circ} \mathrm{C}$. Двигате-

лем постоянного тока контейнер в расплаве приводился во вращение 1500 об/мин, поднимали над поверхностью расплава, сохраняя вращение на 60 с, необходимое для затвердевания металла в контейнере. Вращение контейнера останавливали, свинчивали его с вала ротора. Открывали герметичную крышку с контейнера для извлечения цилиндрического слитка (рис.9). На токарном станке обтачивали половину толщины слитка на пробы.

В соответствии с анализом образцов стружки зон рассчитывали стехиометрическую долю марганца связанного с мышьяком в соединение AsMn c температурой затвердевания $935^{\circ} \mathrm{C}$. Марганец не связанный в кристаллы AsMn считали связанным с оловом в растворенные кластеры $\mathrm{MnSn}_{2}$ с температурой затвердевания $548^{\circ} \mathrm{C}$.

В условиях проведенного опыта частицы кристаллов AsMn среднего диаметра $d_{t}=0,2$ см при вращении $n=1500$ об/мин контейнера с радиусом слоя $R$ от оси испытывают центробежное ускорение. Опыт показал, что в поле центробежных сил фаз кристаллов AsMn и $\mathrm{MnSn}_{2}$ ликвируют к центру со скоростью, а не отбрасываются к периферии.

Скорость осаждения в поле центробежных сил переменная величина, так как с перемещением частицы по радиусу меняется и центробежное ускорение. При этом меняется плотность суспензии кристаллов в олове и изменяется скорость кристаллов с укрупнением кристаллов.

Рисунок 10 показывает, что соединения AsMn и MnSn 2 ликвируют к оси вращения в одинаковой степени. 
По аналогичной методике проверено поведение кристаллов соединений железа в расплаве цинка путем погружения упомянутого контейнера (рис. 9) в расплав гартцинка.

После наполнения контейнера при $450^{\circ} \mathrm{C}$, его поднимали над расплавом, но под теплоизолирующей крышкой и вращали в течение 11 мин со скоростью 1500 об/мин. Затем контейнер

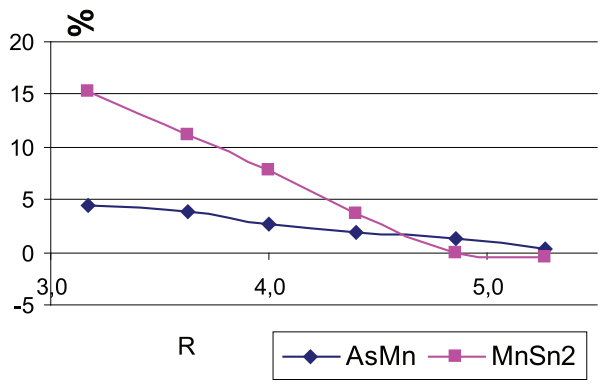

Рис. 10. Изменение содержания примесей в олове в иентробежном поле поднимали над крышкой не прекращая вращения на 5 мин для затвердевания.

От слитка нарезали стружку для проб на разном расстоянии от оси. В табл. 4 приведены результаты расчета.

Та блица 4

Расчет скорости смещения твердых фаз соединения железа под действием центробежной силы

\begin{tabular}{|c|c|c|c|c|c|c|}
\hline $\begin{array}{c}\text { № } \\
\Pi / \Pi\end{array}$ & Параметры & Единица & $\begin{array}{l}\text { Наруж- } \\
\text { ная }\end{array}$ & $\begin{array}{l}\text { Сред- } \\
\text { няя }\end{array}$ & \begin{tabular}{|l} 
Внут- \\
ренняя
\end{tabular} & $\begin{array}{c}\text { Ис- } \\
\text { ходная }\end{array}$ \\
\hline 1 & $\mathrm{Bec}$ & $\Gamma$ & 300 & 85 & 21,7 & 406,7 \\
\hline 2 & Доля объема & & 0,74 & 0,21 & 0,05 & 1 \\
\hline 3 & Концентрация Fe & $\%$ & 9,43 & 0,23 & 8,2 & 7,4 \\
\hline 4 & Концентрация Al & $\%$ & 1,3 & 0,23 & 0,09 & 1,1 \\
\hline 5 & Концентрация $\left[\mathrm{FeAl}_{3}\right]$ & $\%$ & 2,2 & 0,4 & 2,2 & 1,8 \\
\hline 6 & Концентрация $\left[\mathrm{FeZn} \mathrm{Z}_{7}\right]$ & $\%$ & 78,4 & 0,7 & 67,1 & 61,6 \\
\hline 7 & Концентрация [Zn] & $\%$ & 19,4 & 98,9 & 30,7 & 36,6 \\
\hline 8 & Наружный радиус, & $\mathrm{cm}$ & 5,5 & 3,7 & 3,1 & 5,5 \\
\hline 9 & Внутренний радиус, & $\mathrm{cm}$ & 3,7 & 3,1 & 2,9 & 2,9 \\
\hline 10 & Средний $R$ центробежных сил & $\mathrm{cm}$ & 4,6 & 3,4 & 3,0 & \\
\hline 11 & Плотность суспензии & $\rho_{\mathrm{cyc}}, \Gamma / \mathrm{cm}^{3}$ & 7,1 & 6,1 & 6,9 & \\
\hline 12 & $J=$ Ускорение центробежных сил & $\mathrm{M} / \mathrm{c}^{2}$ & 113966 & 84248 & 73808 & \\
\hline 13 & $w_{\mathrm{oc}}=\frac{d_{\mathrm{T}}^{2} \cdot\left(\rho_{\mathrm{T}}-\rho_{\mathrm{c}}\right) \cdot J}{18 \cdot \mu_{\mathrm{c}}} d_{\mathrm{T}}<0,8 \cdot \delta$ & $\mathrm{MM} / \mathrm{c}$ & 0,0043 & 0,032 & 0,006 & $\mathrm{FeZn}_{7}$ \\
\hline 14 & Смещение к периферии $d_{\mathrm{T}}>1,2 \cdot \delta$ & $\mathrm{MM} / \mathrm{c}$ & 0,010 & 0,072 & 0,015 & $\mathrm{FeZn}_{7}$ \\
\hline 15 & Смещение к центру, $d_{\mathrm{T}}>1,2 \cdot \delta$ & $\mathrm{MM} / \mathrm{c}$ & $-0,19$ & $-0,08$ & $-0,116$ & $\mathrm{FeAl}_{3}$ \\
\hline
\end{tabular}


Результаты расчета и фактические анализы показывают, что соединение железа $\mathrm{FeZn}$ с смещается к периферии со скоростью 0,01-0,07 мм/c, а соединения $\mathrm{FeAl}_{3}$ смещаются к центру со скоростью 0,08-0,19 мм/с.

Опыт поведения примеси соединения железа в суспензии расплава гартцинка в полости фильтра в центробежном поле, создаваемом в течение 11 мин. Это условия отстойного расслоения. В условиях же фильтрации фильтр вращается в расплаве в течение 30-60 с и поэтому условия отстоя частиц в полости фильтра не существенны.

\section{4. Отделение жидкого цинка из пор твердого осадка под воздействием центробежной сиды}

В металлургии известна задача очистки твердого осадка от жидкого расплава и ее периодически описывают. Для фильтрации расплавленного алюминия от железа жидкий металл пропускают через кусковой материал. Авторы работы [12] замеряли длительность фильтрации алюминия с температурой $750-800^{\circ} \mathrm{C}$ толщиной слоя $h=10-35$ см через дробленый магнезит разной фракции $d=0,5-2$ см слоем $H=5-20$ см. По полученным данным вычислялась скорость фильтрации по формуле турбулентной фильтрации:

$$
\begin{gathered}
w=\frac{G}{\gamma \cdot F \cdot \tau}, \mathrm{cm} / \mathrm{c}, \\
w=A \cdot \sqrt{d \cdot j}
\end{gathered}
$$

$d$ - размер частиц, см; $\tau$ - время фильтрации, с; $F-$ площадь фильтрации, см ${ }^{2} ; A-$ коэффициент; $j=(h+H) / H-$ гидравлический уклон, т. е. отношение перепада давления в направлении фильтрации к толщине фильтруемого слоя.

По опытным данным рассчитывали эмпирическую зависимость:

$$
w=\left(4,45+0,01 h^{2}+0,001 H^{2}\right) \cdot(h+H) \cdot \frac{\sqrt{d}}{H} .
$$

Формула справедливую только для указанных зернистого материала и фильтруемого металла и в тех пределах в которых построена.

Для наших условий структура формулы (2.2) сохраняется, но диаметр частиц в десятки раз меньше размером и находятся под «гидравлическим уклоном» давлением центробежных сил. Кроме того, фильтрующий слой $H$ меняется по ходу процесса и переменного сечения у постоянной площади фильтрации $F-$ кольца фильтрующей щели. 
Поэтому скорость фильтрации можно оценивать по расчетной скорости циркуляции расплава по наполнении полости фильтра.

Для очистки твердого осадка от жидкого расплава цинка увеличивают скорость врашения фильтра во время подъема ротора с фильтром выше уровня расплава. При этом возрастает величина центробежной силы

$$
G_{\phi}=\frac{m \cdot N_{\mathrm{o}}^{2}}{R},
$$

под действием которой капли $m$ свободного жидкого цинка, не связанного в соединения, выдавливаются из пор твердого осадка. За счет конусности тарелей фильтра нормально составляющая центробежной силы $Q$ (рис. 8), не только выдавливает жидкий расплав из осадка, но и уплотняет, спресовывает осадок под давлением.

В табл. 5 приведены результаты расчета указанных параметров.

Таблица 5

Влияние скорости вращения фильтра на отжиме

\begin{tabular}{|c|c|c|c|c|c|c|c|c|}
\hline $\begin{array}{c}\text { № } \\
\text { П/ா }\end{array}$ & & 2 & 3 & 5 & 6 & 7 & 9 & 10 \\
\hline 1 & Частота вращения отжима, мин & 800 & 850 & 1000 & 1050 & 1050 & 1150 & 1250 \\
\hline 2 & $\mathrm{Zn}_{c v}$ в дроссах, \% & 69,5 & 79,8 & 67,1 & 60,6 & 62,6 & 63,9 & 68,9 \\
\hline 3 & $\left(\mathrm{Zn}_{c v}\right) / \mathrm{Fe}$ в дроссах & 15,9 & 27 & 16 & 14,3 & 14,5 & 7,73 & 7 \\
\hline
\end{tabular}

На рис. 11 показано, что с увеличением скорости вращения $\left(N_{\text {отж}}\right)$ фильтра на отжиме на $20 \%$ снижается выход $\left(\mathrm{Zn}_{c v}\right)$ на единицу удаленного железа $\left(\mathrm{Zn}_{c v} / \mathrm{Fe}\right)$, т.е. на величину возможной очистки дроссов.

На последней стадии цикла под действием центробежной силы $G_{\phi}$ весь осадок из полости фильтра выбрасывается, зачищая стенки конусов от настылей осадка.

Выводы. Показано, что при вращении фильтра в расплаве в полости фильтра создается разрежение которое обеспечивает циркуляцию расплава

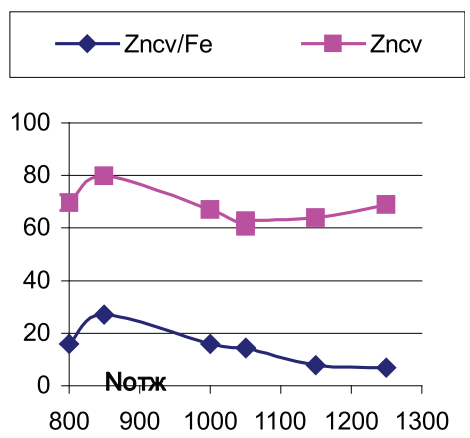

Рис. 11. Влияние частоты вращения на отжиме на выход цинка в дроссы.

Обозначения: $Z n_{c v}-$ содержание свободного, не связанного цинка; $\left(Z n_{c v}\right) / F e-$ содержание свободного цинка на процент железа в дроссах 
через полость и наполнение ее осадком твердых примесей. Показано также, что при вращении фильтра над расплавом за счет центробежных сил происходит прессование осадка и отжатие жидкого не связанного цинка.

\section{5. О моделировании центрифуг фильтрации расплавов погружаемым фидьтром}

Разработчики при переходе от лабораторных до промышленных сталкиваются с необходимостью модельного перехода от лабораторного до более крупного оборудования. При разработке лабораторных и укрупненных центрифуг происходил интуитивный подбор необходимых размеров. Однако, для разработки промышленных аппаратов требовался обоснованный подход.

Авторы в работе [13] рассмотрели требования к определению мощности двигателей центрифуги при изменении ее геометрических размеров, формы котла. Авторы указывают условия подобия течения жидкости от вращения фильтра описываются критериями

Рейнольдса,

$$
\mathrm{Re}=\frac{n \cdot d^{2}}{\mathrm{v}}
$$

Фруда

$$
\mathrm{Fr}=\frac{d \cdot n^{2}}{g}
$$

и Эйлера:

$$
\mathrm{Eu}=\frac{N}{\rho \cdot n^{3} \cdot d^{5}}
$$

где $n$ - число оборотов вращения ротора, об/с; $\rho-$ плотность жидкого расплава, кг $/ \mathrm{M}^{3} ; v-$ кинематический коэффициент вязкости расплава, $\mathrm{M}^{2} / \mathrm{c} ; d-$ диаметр фильтра, м; $N$ - мощность двигателя вращения, $\mathrm{M}^{2} \cdot \mathrm{Kг} / \mathrm{c}^{3} ; g-$ ускорение свободного падения, м/ $\mathrm{c}^{2}$.

Моделируя процесс вращения фильтра на специальном стенде авторы пришли к выводу, что мощность двигателя модели центрифуги подобной ПАВФС-650 можно вычислять по формуле

$$
N=0,08 \cdot \rho \cdot n^{2} \cdot d^{5} .
$$


Другая задача моделирования это оптимизация соотношения диаметра и емкости фильтра к диаметру и объему существующих рафинировочных котлов. Для выбора размеров лабораторных моделей испытывали сменный набор тарелей фильтра разных по диаметру и угла конусности. Для промышленных аппаратов диаметр фильтра по опыту принят в 2-3 раза меньше диаметра существующих рафинировочных котлов. От оптимального соотношения размеров фильтра к размеру котла зависит общая производительность аппарата.

Еще одна задача - это оптимизация скорости вращения фильтра в расплаве при переходе от лабораторных аппаратов к промышленным. Лабораторные аппараты снабжены двигателями постоянного тока, обеспечивающих выбор оптимальной скорости. Для промышленных аппаратов изготавливали шкивы на двигатели разных диаметров, ориентируясь на линейные скорости лабораторных аппаратов. 


\section{Гдава 3. ТЕХНОЯОГИЧЕСКИЕ ОСНОВЫ ЦЕНТРОБЕЖНОЙ ФИЛЬТРАЦИИ ПОГРУЖАЕМЫМ ФИЛЬТРОМ}

Перед изложением показателей рафинирования гартцинка целесообразно рассмотреть некоторые особенности поведения вращающегося конусообразного фильтра, погружаемого в расплав. Поэтому, в этой главе рассмотрим влияние параметров на кинетику отделения твердой фазы примесей с помощью конусного фильтра, погружаемого в расплав.

\section{1. Кинетика наполнения полости фильтра при фильтрации}

Для изучения влияния параметров на показатели центробежной фильтрации проведены опыты по регенерации цинка из отходов ванн цинкования.

В табл. 6 приведены результаты испытания фильтрации гартцинка центрифугой ЦП-200 с погружным фильтром диаметром 200 мм, скоростью вращения фильтра в расплаве 300 мин $^{-1}$, скоростью вращения фильтра на отжиме 900 мин $^{-1}$.

Таблица 6

Результаты центробежной фильтрации гартцинка [5]

\begin{tabular}{|c|c|c|c|c|}
\hline \multirow{2}{*}{ Плавка } & \multicolumn{3}{|c|}{ Содержание железа, \%, в цинке } & Выход, \% \\
\cline { 2 - 5 } & исходном & фильтрате & фильтростатках & фильтростатков \\
\hline 1 & 0,2 & 0,044 & 1,8 & 8,9 \\
\hline 2 & 0,23 & 0,015 & 1,71 & 12,6 \\
\hline 3 & 0,32 & 0,076 & 3,74 & 6,7 \\
\hline 4 & 0,32 & 0,07 & 4,66 & 5,5 \\
\hline 5 & 1,83 & 0,3 & 23,7 & 16 \\
\hline 6 & 4,83 & 0,11 & 33 & 15 \\
\hline
\end{tabular}

Испытания показали перспективность использования погружаемого фильтра для очистки гартцинка с различным исходным содержанием железа. Фильтростатки получаются сыпучими, кристаллическими и являются удобной моделью для исследования общих характеристик центробежной фильтрации погружаемым фильтром. 
Общая производительность процесса рафинирования погружаемым фильтром всецело зависит от полного заполнения полости фильтр осадком. Вначале операции рафинирования фильтр быстро наполняется осадком дроссов. Через некоторое время процесса фильтрации, погруженным фильтром, именуемое как «длительность фильтрации в обозначении $\mathbf{B}$ » снижается наполнение фильтра и приходится с помощью реле времени увеличивать длительность вращения фильтра в погруженном состоянии. С увеличением длительности вращения фильтра в погруженном состоянии увеличивается вес осадка в фильтре.

На рис. 12 показан скачек увеличения наполнения фильтра при добавлении длительности вращения фильтра в погруженном состоянии.

Для оценки наполнения фильтра используется параметр, характеризующийся как «производительность заполнения фильтра $Q$, кг/мин» в течение вращения фильтра в состоянии,

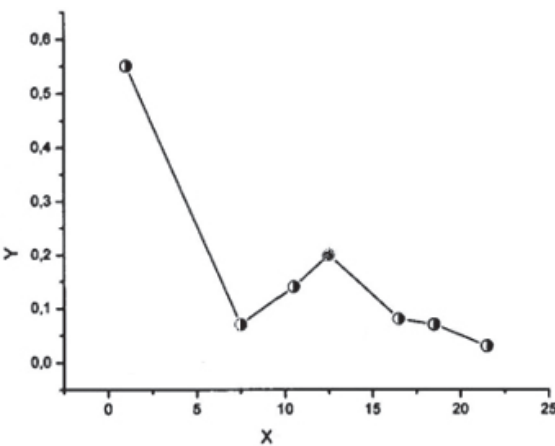

Рис. 12. Кинетика изменения наполнения фильтра:

$X$ - длительность фильтации, $B$, мин; $Y$ - вес наполнения фильтра, кг погруженном в расплав. Производительность наполнения фильтра $Q$ означет вес осадка за время $B$ вращения фильтра в расплаве [6].

Суммарная длительность циклов погружения фильтра в расплав для его заполнения осадком до необходимой степени очистки расплава от твердой примеси именуется как «длительность процесса центробежной фильтрации, Д, в мин».

В процессе фильтрации производительность наполнения фильтра снижется и объясняется это снижением концентрации твердых примесей железа в расплаве.

Статистическая обработка опытов на рис. 13 показала, что производительность наполнения фильтра зависит от содержания твердой фазы соединений железа в расплаве по уравнениям:

$$
\begin{gathered}
Q_{9}=1,1 \cdot[\mathrm{Fe}]_{\mathrm{rs}}-0,32 \text { с корреляцией } 0,84 ; \\
Q_{27}=1,68 \cdot[\mathrm{Fe}]_{\mathrm{rs}}-0,92 \text { с корреляцией } 0,79 .
\end{gathered}
$$




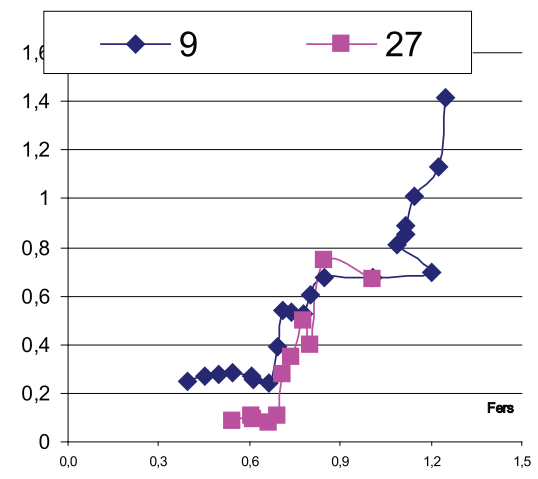

Рис. 13. Влияние содержания $[\mathrm{Fe}]_{r s}$ на производительность наполнения фильтра.

Примечание: оп 9-температура фильтрации $-490^{\circ} \mathrm{C}$; скорость вращения в расплаве 420 мин $^{-1}$; оп27 - Температура фильтрации $-480^{\circ} \mathrm{C}$; скорость вращения в расплаве 240 мин $^{-1}$
При погружении фильтра в расплав гартцинка, содержащем $0,6 \%$ железа полость фильтра объемом 0,56 дм $^{3}$ заполнится расплавом плотностью 6,9 кг/дм ${ }^{3}$, т.е. по весу это составит $0,56 \cdot 6,9=3,86$ кг. В этом объеме содержится твердая фаза соединения $\mathrm{FeZn}_{10}$ (плотностью $7,21 \mathrm{\kappa г} / \mathrm{cm}^{3}$ ) весом 0,549 кг.

При повторных циклах полость фильтра от фильтрующей щели по заборные окна может заполнится дроссами плотностью 2,19 кг/дм ${ }^{3}$,т. е. по весу $0,56 \cdot 2,19=1,23$ кг. За 1 мин вращения фильтра в погруженном состоянии фактически получено 1,25 кг дроссов с содержанием $4 \% \mathrm{Fe}$.

Для заполнения фильтра этим весом дроссов полость должна заполняться несколькими объемами $(1,25 / 0,549=2,28$ объемов), т. е. через полость должен циркулировать расплав. Значит, полость фильтра непрерывно обновляется расплавом, т.е. расплав циркулирует через полость фильтра. Производительность циркуляции можно упрощено рассчитать по заполнению осадком в фильтре кристаллами железа из расплава во время вращения фильтра в течение 1 мин и будет составлять $10 \mathrm{kг} /$ мин.

В конце процесса рафинирования при содержании в расплаве $0,27 \% \mathrm{Fe}$ для наполнения полости фильтра при его вращения в течение 1 мин с фильтра разгружено 0,25 кг дроссов с $2,8 \% \mathrm{Fe}$, т.е. через фильтр прокачано

$$
(0,25 \cdot 2,8) /(1 \cdot 0,27)=2,6 \text { кг/мин расплава. }
$$

Однако, при низком сопротивлении малого слоя осадка в фильтре и низкого содержания железа циркуляция расплава гораздо выше.

В предыдущей главе приведен расчет теоретической производительности расплава через полость при скорости вращения 360 об/мин фильтра в расплаве равной 4,9 кг/мин. 
На рис. 14 стрелкой показано заполнение расплава в полость фильтра и стрелкой выброс жидкой фазы через фильтрующую щель.

Схема поясняет, что при вращении фильтра в расплаве в полость фильтра всасывается суспензия твердых примесей и под действием центробежных сил выбрасывается в объем расплава, а твердые примеси накапливаются в полости фильтра. В табл. 7 приведена кинетика наполнения фильтра на примере удаления железа из гатрцинка.

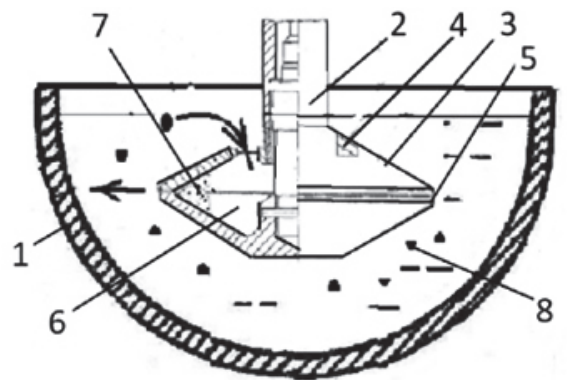

Рис. 14. Схема циркуляции расплава через фильтр. Узлы: 1 -котел; 2 - ротор вращения фильтра; 3- тарель; 4-заборные окна; 5 - щель фильтрации; 6 - полость фильтра для осадка;

7 - собраная твердая фаза; 8- твердые кристаллы суспензии расплава

Та блица 7

Кинетика наполнения фильтра и циркуляция расплава через фильтр

\begin{tabular}{|c|c|c|c|c|c|c|}
\hline $\begin{array}{c}\text { Длительность } \\
\text { наполнения } \\
\text { фильтра, мин }\end{array}$ & $\begin{array}{c}{[\mathrm{Fe}] \text { в ме- }} \\
\text { талле, } \%\end{array}$ & $\begin{array}{c}\text { Вес } \\
\text { дрос- } \\
\text { сов, кг }\end{array}$ & $\begin{array}{c}{[\mathrm{Fe}]} \\
\text { в дрос- } \\
\text { cax, } \%\end{array}$ & $\begin{array}{c}\text { Степень } \\
\text { удаления } \\
\text { Fе, } \%\end{array}$ & $Q_{f}$, кг/мин & $V_{\text {цирк }, \text { кг/мин }}$ \\
\hline 1 & 0,6 & 1,25 & 4,0 & 10,1 & 1,25 & 15,1 \\
\hline 2 & 0,55 & 1,12 & 3,6 & 18,4 & 1,12 & 14,7 \\
\hline 4 & 0,50 & 0,99 & 3,8 & 26,2 & 0,50 & 8,1 \\
\hline 6 & 0,46 & 0,86 & 3,4 & 32,0 & 0,43 & 7,5 \\
\hline 8 & 0,43 & 0,73 & 3,3 & 37,0 & 0,37 & 7,6 \\
\hline 10 & 0,40 & 0,6 & 3,5 & 41,3 & 0,30 & 8,0 \\
\hline 11 & 0,38 & 0,3 & 3,2 & 44,2 & 0,30 & 8,9 \\
\hline 13 & 0,36 & 0,46 & 3,3 & 47,3 & 0,23 & 8,2 \\
\hline 15 & 0,34 & 0,58 & 3,5 & 51,4 & 0,29 & 6,5 \\
\hline 17 & 0,32 & 0,51 & 3,0 & 54,5 & 0,26 & 5,9 \\
\hline 19 & 0,30 & 0,49 & 3,0 & 57,5 & 0,25 & 6,6 \\
\hline 22 & 0,28 & 0,43 & 2,6 & 59,7 & 0,14 & 5,5 \\
\hline 23 & 0,27 & 0,25 & 2,8 & 61,1 & 0,25 & 6,6 \\
\hline 24 & 0,26 & 0,1 & 2,4 & 61,6 & 0,1 & 5,4 \\
\hline
\end{tabular}




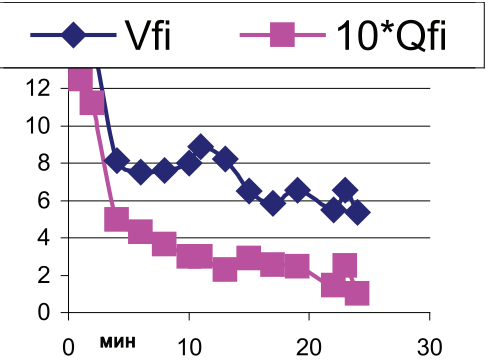

Рис. 15. Изменение производительности наполнения фильтра и циркуляции расплава через фильтр.

Обозначения: по абсииссе:

$B_{\text {fil }}-$ длительность фильтрации, мин; по ординате: $Q_{f}-$ производительность наполнения фильтра;

$V_{f l}-$ производительность циркуляции расплава, кг/мин
Условия опыта. Длительность вращения фильтра в цикле - 60 с; частота вращения фильтра $n=240 \mathrm{Mин}^{-1}$; Температура фильтрации $480^{\circ} \mathrm{C}$.

При исследовании кинетики наполнения погружного фильтра дроссами показана оценка производительности циркуляции расплава через фильтр.

На рис. 15 показано, что скорость движения жидкости через щель в короткий момент (пока щель свободна) производительность фильтра высокая, но по ходу процесса скорость циркуляции расплава снижается, так как поры забиваются. Таким образом, производительность наполнения фильтра зависит от содержания твердого в расплаве, характеризуемое содержанием твердых соединений железа и скорости циркуляции расплава через фильтр.

Точнее циркуляцию расплава через фильтр характеризовать содержанием в расплаве твердой фазы $\left[\mathrm{FeZn}_{10}\right]$, а не [Fe]. Однако, параметр производительность циркуляции расплава через фильтр не регулируемый параметр, а характеризует внутреннее состояние расплава и зависит не только от [Fe], но и от их дисперсности и равновесия перекристаллизации фаз $\mathrm{FeZn}_{3}, \mathrm{FeZn}_{7}, \mathrm{FeZn}_{10}$.

Связь производительности наполнения фильтра и производительность циркуляции расплава через полость фильтра характеризуется их соотношением, т. е. показателем $V / Q$.

Из табл. 8 видно, что с увеличением длительности фильтрации повышается показатель $V / Q$ (превышение производительности циркуляции над производительностью наполнения фильтра), и повышается выход свободного цинка $\mathrm{Zn}_{c v} /[\mathrm{Fe}]$ относительно соединений железа в дроссах.

На рис. 16 также показано, что с увеличением длительности процесса повышается показатель $V / Q$ (кратность превышения производительности циркуляции над производительностью наполнения фильтра) по уравнению:

$$
V / Q=1,28 \cdot \min +7,9 \text { с корреляцией } 0,77 \text {. }
$$


Таблица 8 Изменение содержания свободного цинка в дроссах по ходу фильтрации

\begin{tabular}{|c|c|c|c|c|c|c|c|c|c|}
\hline \multirow{3}{*}{$\begin{array}{c}\text { Забор } \\
\text { от } \\
\text { нач., } \\
\text { мин }\end{array}$} & \multirow{3}{*}{$\begin{array}{c}\mathrm{Bec} \\
\text { дрос- } \\
\text { сов, } \\
\text { Кг }\end{array}$} & \multicolumn{2}{|c|}{ Анализ } & \multirow{3}{*}{$\begin{array}{c}\mathrm{St}_{\mathrm{ud}} \\
\mathrm{Fe}\end{array}$} & \multirow{3}{*}{$\begin{array}{c}\text { sum } \\
\text { тв ф3, } \\
\% \text { с } \mathrm{Zn}_{7}\end{array}$} & \multirow{3}{*}{$\begin{array}{c}Q \\
\text { наполн., } \\
\text { кг/мин }\end{array}$} & \multirow{3}{*}{$\begin{array}{c}V_{t v} \\
\text { циркул. } \\
\text { Кг/мин }\end{array}$} & \multirow{3}{*}{$\mathrm{Zn}_{c v} /[\mathrm{Fe}]$} & \multirow{3}{*}{$V / Q$} \\
\hline & & $\begin{array}{c}\text { дрос- } \\
\text { сов }\end{array}$ & $\begin{array}{l}\text { pac- } \\
\text { плав. }\end{array}$ & & & & & & \\
\hline & & $\mathrm{Fe} \%$ & $\mathrm{Fe} \%$ & & & & & & \\
\hline 0,7 & 1,1 & 5,88 & 0,53 & 10,9 & 4,49 & 1,57 & 16,7 & 11,2 & 10,6 \\
\hline 1,4 & 0,82 & 5,88 & 0,49 & 19,0 & 4,13 & 1,17 & 13,5 & 12,2 & 11,5 \\
\hline 2,1 & 0,87 & 5,88 & 0,44 & 27,7 & 3,74 & 1,24 & 15,8 & 13,5 & 12,7 \\
\hline 2,8 & 0,9 & 5,88 & 0,39 & 36,6 & 3,33 & 1,29 & 18,4 & 15,1 & 14,3 \\
\hline 3,5 & 0,76 & 4,36 & 0,36 & 42,2 & 3,08 & 1,09 & 12,3 & 20,6 & 11,3 \\
\hline 4,2 & 0,71 & 4,36 & 0,33 & 47,4 & 2,84 & 1,01 & 12,4 & 22,4 & 12,2 \\
\hline 4,9 & 0,51 & 4,14 & 0,31 & 50,9 & 2,67 & 0,73 & 9,1 & 24,4 & 12,5 \\
\hline 5,6 & 0,46 & 4,14 & 0,29 & 54,2 & 2,52 & 0,66 & 8,7 & 25,8 & 13,3 \\
\hline 6,3 & 0,21 & 3,86 & 0,28 & 55,5 & 2,46 & 0,30 & 3,8 & 27,4 & 12,7 \\
\hline 7 & 0,48 & 3,86 & 0,26 & 58,6 & 2,31 & 0,69 & 9,4 & 29,1 & 13,7 \\
\hline 7,7 & 0,4 & 3,33 & 0,25 & 60,9 & 2,20 & 0,57 & 7,0 & 32,6 & 12,3 \\
\hline 8,4 & 0,66 & 4,31 & 0,22 & 65,7 & 1,96 & 0,94 & 17,5 & 32,0 & 18,5 \\
\hline 9,1 & 0,35 & 4,31 & 0,21 & 68,2 & 1,83 & 0,50 & 10,0 & 34,2 & 20,0 \\
\hline 9,8 & 0,41 & 4,28 & 0,19 & 71,2 & 1,67 & 0,59 & 13,2 & 37,1 & 22,6 \\
\hline 10,5 & 0,17 & 4,28 & 0,18 & 72,4 & 1,60 & 0,24 & 5,7 & 38,7 & 23,6 \\
\hline 11,2 & 0,18 & 4,28 & 0,17 & 73,7 & 1,53 & 0,26 & 6,3 & 40,5 & 24,7 \\
\hline 11,9 & 0,03 & 4,28 & 0,17 & 73,9 & 1,52 & 0,04 & 1,1 & 40,8 & 24,8 \\
\hline
\end{tabular}

Приложение: температура фильтрации $-500^{\circ} \mathrm{C}$; частота вращения фильтра в расплаве -240 мин $^{-1}$.

Выход свободного жидкого $\mathrm{Zn}$ в дроссы относительно твердых фаз соединений железа повышается с увеличением длительности фильтрации по уравнению:

$$
\begin{gathered}
\mathrm{Zn}_{c v} /[\mathrm{Fe}]=2,8 \cdot \min +9,3 \\
\text { с корреляцией } 0,99 .
\end{gathered}
$$

Это объясняется снижением содержания твердой фазы мелкой фракции соединений железа, которая связывает на своей поверхности жидкую пленку цинка. Это подтверждается на рис. 17.

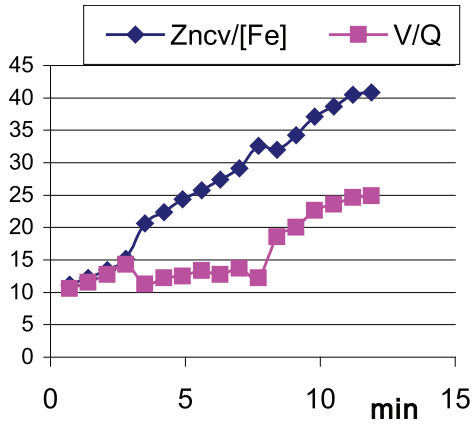

Рис. 16. Изменение показателя $V / Q$ расплава и $\mathrm{Zn}$ cv $/[\mathrm{Fe}]$ по ходу процесса фильтрации 
B начале фильтрации при содержании Fe более 0,3\% зависимость описывается уравнением:

$$
V / Q=26,6-35,7 \cdot[\mathrm{Fe}]_{r s} \text { с корреляцией } 0,61 .
$$

Со снижении содержания $\mathrm{Fe}$ менее $0,3 \%$ резко увеличивается превышение циркуляции расплава по сравнению с производительностью наполнения фильтра. С уменьшением содержания железа в расплаве планомерно повышается выход свободного цинка относительно содержания соединений железа по уравнению:

$$
\mathrm{Zn}_{c v} /[\mathrm{Fe}]=52,6-86,1 \cdot[\mathrm{Fe}]_{r s} \text { с корреляцией 0,95. }
$$

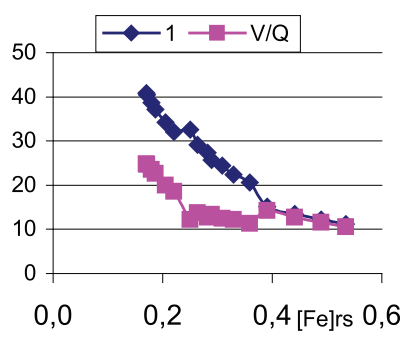

Рис. 17. Влияние содержания железа в расплаве на превышение циркуляции над наполнением.

Примечание: температура фильтрации $-500^{\circ} \mathrm{C}$; частота вращения фильтра в расплаве 240 мин $^{-1} ; 1-\mathrm{Zn}_{\mathrm{cv}} /[\mathrm{Fe}]-$ выход свободного цинка в дроссы относительно твердой фазы соединений железа

В разбавленной суспензии чтобы наполнить фильтр требуется многократная циркуляция расплава.

Расчетная производительность циркуляции расплава через полость конических тарелей со свободной щелью зависит от скорости вращения фильтра в расплаве. Для рассматриваемого опыта при скорости вращения 240 об/мин производительность циркуляции расплава через фильтр (по расчету в главе 2) должна составлять 6,1 кг/мин. Фактическая скорость циркуляции зависит от проницаемости осадка, создаваемого сопротивления скорости расплава через поры осадка и щель.

Производительность циркуляции, рассчитанная по количеству накопления железа в фильтре тоже не отражает фактическую производительность циркуляции, так как часть кристаллов соединений железа может быть настолько мелкодисперсная, что не задерживается в порах осадка и поэтому фактическая циркуляция больше, чем расчетная.

В целом можно сделать вывод, что для обеспечения производительности рафинирования необходимо обеспечить полное заполнение полости фильтра, которое создается самоустанавливающейся производительностью циркуляции расплава через полость фильтра.

Изучение влияния параметров процесса на виртуальный показатель «производительность циркуляции» преследует цель выявить условия максимального заполнения полости осадком. 
Если в начале процесса на реле установлена излишне большая длительность вращения фильтра в расплаве, то фильтр заполняется за короткое время, но продолжает вращаться в расплаве с уже заполненной полостью и в многократных циклах это снижает общую производительность процесса. В конце процесса рафинирования эта установленная длительность может быть недостаточна для заполнения фильтра, то во всех циклах из расплава поднимается полупустой фильтр. Это также снижает общую производительность процесса рафинирования.

Для повышения общей производительности фильтрации путем сокращения количества циклов с недостаточно наполненной полостью фильтра предложено [14] устройство управления процессом оптимизации наполнения фильтра.

Для осуществления способа опора 10 ротора-фильтра 3 снабжена торроидальным дифференциальным гидравлическим датчиком ТГД давления 17. К гидродатчику давления подсоединен электрический преобразователь давления 18 из сапфировых элементов. Преобразователь давления через устройство сопряжения соединено с анализатором, таймером, задатчиком, блоком управления приводами связанных с процессором.

При автоматическом погружении и поднятии фильтра измеряется дифференциальным датчиком сила давления вращающегося ротора (рис. 18) фильтра на опору подшипника до погружения в расплав и после подъема из расплава. Определяется прирост силы давления, который сравнивается с заданным значением и блок управления регулирует длительность вращения ротора-фильтра в расплаве. Причем при отрицательном значении разности повышается длительность вращения ротора-фильтра в расплаве, а при положительном значении длительность вращения роторафильтра изменяется наоборот.

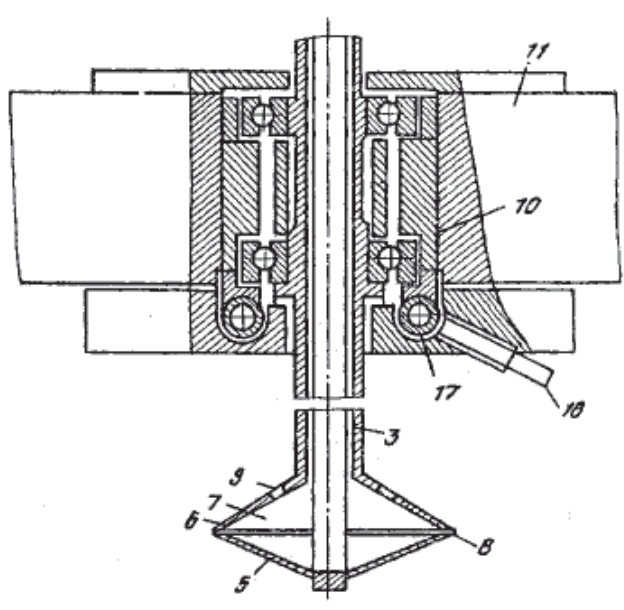

Рис. 18. Ротор с фильтром.

Основные узлы: 3 - ротор с тарелями; 8- фильтрующая щель; 9- заборные окна; 10 - опора подшипников; 17 - гидродатчик давления; 18 - электропреобразователь давления 


\section{2. Влияние частоты вращения на скорость наполнения полости фильтра осадком}

Скорость вращения фильтра в расплаве влияет на скорость циркуляции расплава через заборные окна и щель. С повышением ско-

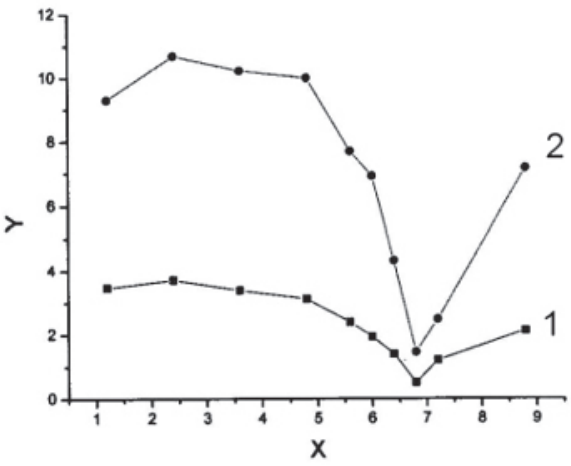

Рис. 19. Производительность фильтра при изменении скорости вращения по ходу фильтрации:

$X$ - длительность фильтации, $B_{f i l}$, мин; по ординате $Y$ :

1 - производительность наполнения фильтра,

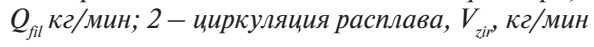

рости циркуляции расплава через заборные окна в полость фильтра повышается производительность наполнения фильтра [6].

На рис. 19 показано снижение наполнение фильтра и циркуляции расплава через полость фильтра с течением времени, но при изменении скорости вращения происходит начальное резкое повышение наполнения фильтра. По мере продолжения фильтрации снижение веса осадка в наполнении фильтра объясняется снижением концентрации твердых примесей железа в расплаве.

Таблица 9

Влияние частоты вращения фильтра на скорость его наполнения

\begin{tabular}{|c|l|c|c|c|c|c|c|c|}
\hline $\begin{array}{c}\text { № } \\
\text { П/п }\end{array}$ & & 1 & 2 & 3 & 4 & 5 & 6 & 7 \\
\hline 1 & Частота вращения фильтра, мин & & & \\
\hline 2 & Производительность фильтра, кг/мин & 0,6 & 0,5 & 0,33 & 0,21 & 0,11 & 0,1 & 0,28 \\
\hline
\end{tabular}

В табл. 9 показано влияние частоты вращения фильтра в расплаве на скорость движения жидкости через окна и щель, т. е. влияет на производительность циркуляции суспензии расплава через полость.

С повышением частоты вращения фильтра с 200 до 350 мин $^{-1}$ производительность наполнения фильтра как показано на рис. 20 снижается, а с повышением более 400 мин $^{-1}$ несколько увеличивается. Это можно 
объяснить тем, что центробежная сила при повышенной скорости вращения увеличивает циркуляцию расплава через плотный осадок, повышая наполнение. Это зависит от состояния кристаллов осадка особенно при малых концентрациях твердой фазы. На начальном этапе фильтрации оптимальная частота вращения фильтра в расплаве гартцинка составляет 250 мин $^{-1}$.

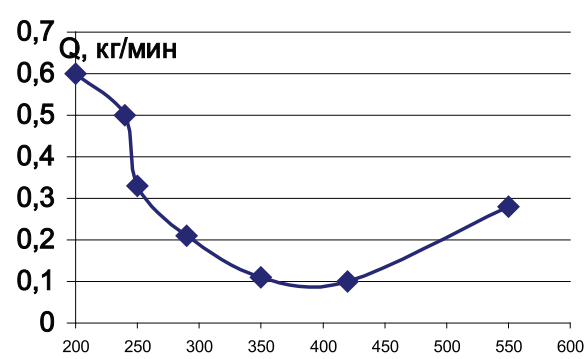

$\mathrm{n}$, мин $^{-1}$

Рис. 20. Влияние частоты вращения фильтра на скорость его наполнени

\section{3. Влияние глубины погружения окон фильтра на скорость наполнения фильтра твердой фазой}

Глубина погружения фильтра в расплаве влияет на кинетику захвата плавающих частиц с поверхности и на кинетику захвата донного осадка.

Таблица 10

Влияние глубины погружения фильтра на его заполнение

\begin{tabular}{|c|l|c|c|c|c|c|}
\hline $\begin{array}{c}\text { № } \\
\text { п/п }\end{array}$ & \multicolumn{1}{|c|}{1} & 2 & 3 & 4 & 5 \\
\hline 1 & Глубина погружения фильтра & 3 & 3,7 & 4 & 8,3 & 10,4 \\
\hline 2 & Скорость забора в среднем $Q_{\text {сред }}$ & 0,8 & 0,41 & 0,50 & 0,38 & 0,10 \\
\hline 3 & То же, для совместимости масштаба, $5 \cdot Q_{\text {сред }}$ & 3,9 & 2,1 & 2,5 & 1,9 & 0,5 \\
\hline
\end{tabular}

Статистическая обработка опытов показала, что с увеличением глубины погружения фильтра в расплав с 3 до 6 см производительность наполнения фильтра снижается по уравнению:

$$
5 \cdot Q_{i s}=0,8-0,06 \cdot h \text { с корреляцией } 0,72 .
$$

Это объясняется малым различием плотности твердой и жидкой фазы и от интенсивности дополнительного перемешивания расплава.

Оптимальная глубина погружения фильтра для начальной производительности наполнения фильтра составляет 2-3 см

В течение процесса фильтрации уровень расплава снижается и глубина погружения фильтра отклоняется от заданного. Для обеспечения 


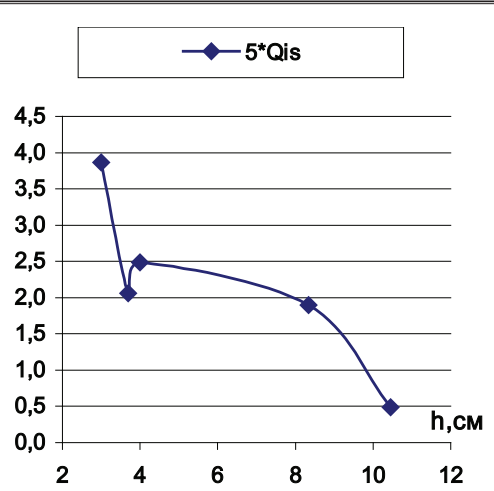

Рис. 21. Влияние глубины погружения фильтра в расплав на наполнение фильтра. По абсциссе - глубина погружения фильтра, см;

$5 \cdot Q_{i s}-$ производительность наполнения фильтра, кг/мин

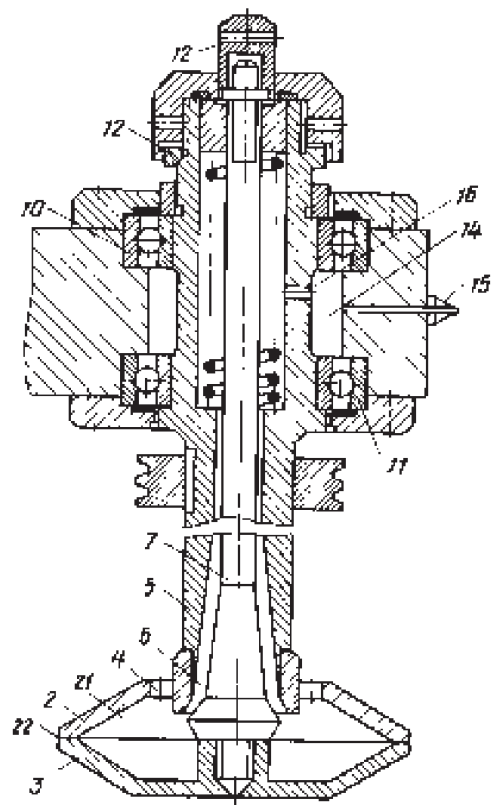

Рис. 22. Ротор с устройством контроля погружения фильтра погружения фильтра в каждом цикле на необходимую глубину предложено [15] устройство регулировки погружения по ходу процесса, включающее изменение узла подвески ротора фильтра.

Ротор с фильтром на подшипниковой опоре подвешен на траверсе 9, которая вертикально перемещает ротор с фильтром. Между подшипниками расположен кольцевой паз 14, снабженный штуцером 15 для подачи газа внутрь паза через штуцер 16. Газ проходит в полость ротора и выдавливается из его нижней части внутрь фильтра и в расплав суспензии. Это обеспечивает возможность по давлению газа в интервале 3-20 мм рт. ст. в каждом цикле фиксировать глубину погружения фильтра.

Показание давления газа в линии подачи после тарировки служит показателем глубины погружения фильтра в расплав и датчиком его регулировки. Трубчатый ротор 5 погружается в расплав до заданного значения давления газа, соответствующего уровню заглубления заборных окон 4. Суспензия расплава с твердыми примесями поступает через заборные окна 4 в полость 21 фильтра, под действием центробежных сил жидкий расплав продавливается через фильтрующую щель 22 и выбрасывается в расплав, а твердые кристаллы остаются в полости 21 фильтра. После накопления твердых кристаллов в полости 21 фильтр при помощи траверсы 9 
приподнимается, не прекращая вращения, до положения 23, и происходит «досушка» осадка. В этот момент подаваемый воздух выдавливает из зазора 6 между валом 7 и трубчатым ротором 5 остатки расплава.

Уменьшение давления ротора фильтра на опору подшипника [15] при максимально достигнутой длительности цикла может быть сигналом для повышения скорости вращения и глубины погружения фильтра.

\section{4. Влияние частоты вращения фидьтра над расплавом на степень очистки твердого от расплава}

В положении ротора с фильтром выше уровня расплава увеличивают скорость вращения фильтра. При этом возрастает величина центробежной силы

$$
G_{\phi}=\frac{m \cdot N_{\mathrm{o}}^{2}}{R},
$$

под действием которой капли $m$ свободного жидкого цинка, не связанного в соединения, выдавливаются из пор твердого осадка.

За счет конусности тарелей фильтра нормально составляющая центробежной силы $Q$ (рис. 8), не только выдавливает жидкий расплав из осадка, но и уплотняет, спрессовывает осадок под давлением. В табл. 11 приведены результаты влияние частоты вращения фильтра на выходе из расплава.

Таблица 11

Влияние частоты вращения фильтра Д - 200 мм на отжиме

\begin{tabular}{|c|l|c|c|c|c|c|c|c|}
\hline $\begin{array}{c}\text { № } \\
\text { П/п }\end{array}$ & & 1 & 2 & 3 & 4 & 5 & 6 & 7 \\
\hline 1 & Частота вращения отжима, мин ${ }^{-1}$ & 800 & 850 & 1000 & 1050 & 1050 & 1150 & 1250 \\
\hline 2 & Содержание в дроссах $[\mathrm{Zn}]_{\text {своб }}$ & 69,5 & 79,8 & 67,1 & 60,6 & 62,6 & 63,9 & 68,9 \\
\hline 3 & Средняя доля в дроссах $\left([\mathrm{Zn}]_{\text {своб }}\right) / \mathrm{Fe}$ & 15,9 & 27 & 16 & 14,3 & 14,5 & 7,73 & 7 \\
\hline
\end{tabular}

Опыт показал, что длительность подъема фильтра над расплавом, которая составляет 1-2 мин, достаточна для выделения брызг расплава при скорости вращения фильтра более 950 об/мин [16].

На рис. 23 показано, что с увеличением скорости вращения фильтра над расплавом на $20 \%$ снижается выход свободного, не связанного цинка, на единицу удаленного железа. 


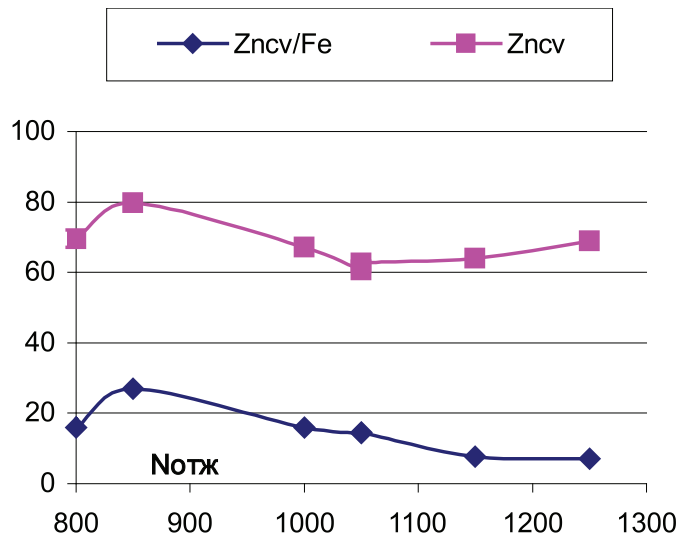

Рис. 23. Влияние частоты вращения на отжиме на выход цинка в дроссы.

Обозначения: по абсииссе - частота вращения фильтра над расплавом, $N_{\text {отэю }}$; по ординате - концентрация цинка в дроссах не связанного в твердые соединения, $[\mathrm{Zn}]_{c v}$; содержание свободного иинка в дроссах относительно содержания железа в них $\left([\mathrm{Zn}]_{c v}\right) /[\mathrm{Fe}]$

На последней стадии цикла под действием центробежной силы $G_{\phi}$ весь осадок из полости фильтра выбрасывается, зачищая стенки конусов от настылей осадка.

Выводы. Показано, что при вращении фильтра в расплаве в полости фильтра создается разрежение которое обеспечивает циркуляцию расплава через полость и наполнение ее осадком твердых примесей. Показано также, что при вращении фильтра над расплавом за счет центробежных сил происходит прессование осадка и отжатие не связанного жидкого цинка. 


\title{
ГДава 4. ФИЗИКО-ХИМИЧЕСКИЕ ИСС ДЕДОВАНИЯ ФАЗ ФИЯЬТРОСТАТКОВ
}

\author{
4.1. Диаграмма состояния \\ и термодинамика преобразования фаз
}

Процесс фильтрации расплава гартцинка от примеси железа при температуре $600-450^{\circ} \mathrm{C}$ описывается изменением состава расплава в соответствии с диаграммой системы $\mathrm{Zn}-\mathrm{Fe}-\mathrm{Al}$.

По диаграмме состояния системы $\mathrm{Zn}-\mathrm{Fe}$ (рис. 24) известны при температуре ниже $530^{\circ} \mathrm{C}$ стабильные фаза $\delta_{1}$ состава $\mathrm{FeZn}_{7}$ и фаза $\xi$ состава $\mathrm{FeZn}_{10}[17 ; 18]$.

При содержании железа менее $3 \%$ и снижении температуры расплава в диапазоне 672-620 ${ }^{\circ} \mathrm{C}$ железо выделяется в виде фазы $\delta$ с переменным составом от $\mathrm{FeZn}_{9}\left(672^{\circ} \mathrm{C}\right)$ до $\mathrm{FeZn}_{11}\left(649^{\circ} \mathrm{C}\right)$ и затем в $\mathrm{FeZn}_{8}\left(620^{\circ} \mathrm{C}\right)$. При охлаждении от температуры 620 до $530^{\circ} \mathrm{C}$ происходит кристаллизация в фазу $\delta_{1}$ переменного состава $\mathrm{FeZn}_{8}$ и $\mathrm{FeZn} \mathrm{n}_{11}$. При охлаждении от температуры 530 до $420^{\circ} \mathrm{C}$ происходит кристаллизация в фазу $\xi$ состава $\mathrm{FeZn} \mathrm{z}_{7}$ с тем-

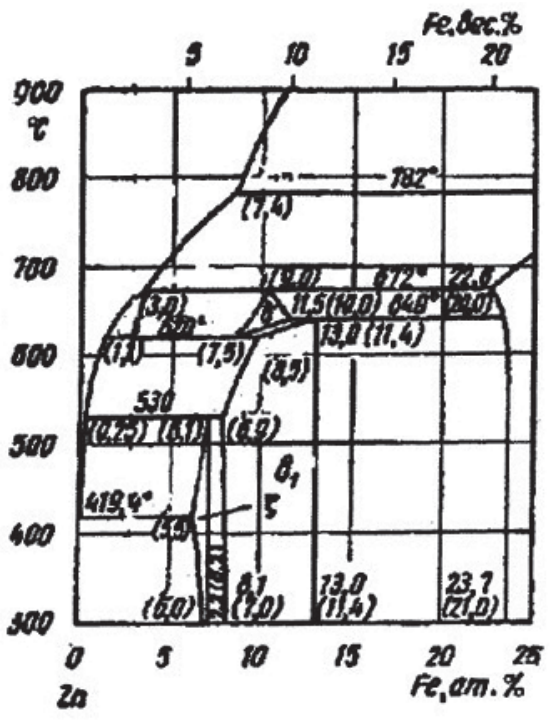

Pис. 24. Диаграмма состояния системы $\mathrm{Zn}-\mathrm{Fe}$ пературой плавления $530^{\circ} \mathrm{C}$.

В промышленных условиях реальный диапазон температур фильтрации $600-460^{\circ} \mathrm{C}$. Поэтому в расплаве в процессе достижения равно-

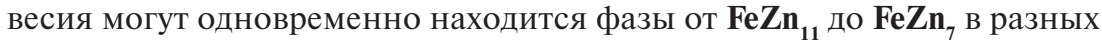
соотношениях.

Высокий выход цинка в отфильтрованные дроссы (показатель $\mathrm{Zn} / \mathrm{Fe}$ ) объясняется образованием кристаллов $\mathrm{FeZn}_{(7-10)}$ различной крупности, покрытых пленкой жидкого цинка за счет высокой смачиваемости фаз. 
В присутствии алюминия в гартцинке железо образует более тугоплавкую фазу $\Theta \mathrm{FeAl}_{3}\left(1173^{\circ} \mathrm{C}\right)$ и фазу $\eta \mathrm{Fe}_{2} \mathrm{Al}_{5}\left(1165^{\circ} \mathrm{C}\right)$, в соответствии с диаграммой [17; 19] состояния системы Fe-Al (рис. 25), которые имеют низкую растворимость в $\mathrm{Zn}$.

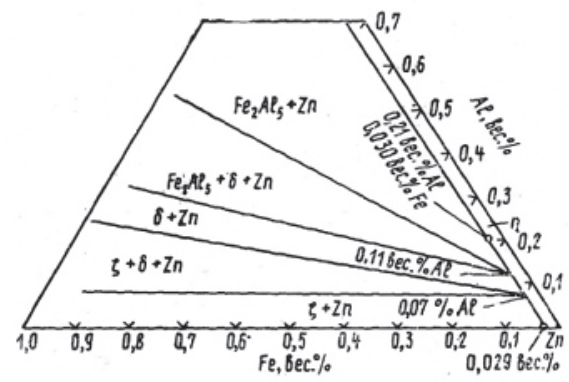

Рис. 25. Изотермический разрез угла системы при $400^{\circ} \mathrm{C}$

Табли и а 12

Фазы соединений железа в системе $\mathrm{Fe}-\mathrm{Al}$

\begin{tabular}{|c|c|c|c|c|c|}
\hline Формула & Фаза & $T_{\text {плавгения }}$ & $\mathrm{Al}_{\text {вес }}, \%$ & $\mathrm{Fe}_{\text {вес }}, \%$ & $(\mathrm{Al} / \mathrm{Fe})_{\text {at }}$ \\
\hline $\mathrm{Fe}_{3} \mathrm{Al}$ & $\alpha$ & 1390 & 13,9 & 86,1 & 0,33 \\
\hline $\mathrm{FeAl}$ & $\beta$ & 1403 & 32,7 & 67,3 & 1,0 \\
\hline $\mathrm{FeAl}_{2}$ & $\zeta$ & 1158 & 49,3 & 50,7 & 2,0 \\
\hline $\mathrm{Fe}_{2} \mathrm{Al}_{5}$ & $\eta$ & 1165 & 54,8 & 45,2 & 2,5 \\
\hline $\mathrm{FeAl}_{3}$ & $\theta$ & 1160 & 59,3 & 40,7 & 3,0 \\
\hline
\end{tabular}

В суспензии расплава твердых кристаллов $\mathrm{FeZn}_{x}$ в цинке в присутствии алюминия могут проходить реакции [20]:

$$
\begin{aligned}
2 \mathrm{FeZn}_{10}+5 \mathrm{Al} & =\mathrm{Fe}_{2} \mathrm{Al}_{5}+20 \mathrm{Zn} \\
\mathrm{FeZn}_{10}+3 \mathrm{Al} & =\mathrm{FeAl}_{3}+10 \mathrm{Zn} \\
\mathrm{FeZn} & +3 \mathrm{Al}=\mathrm{FeAl}_{3}+7 \mathrm{Zn} .
\end{aligned}
$$

Расчет термодинамических реакций с использованием термодинамических данных [21] в программе TERRA [22] показал, что предпочтительно идет реакция (4.1) при $500^{\circ} \mathrm{C}$ при $\mathrm{Al} / \mathrm{Fe}_{\text {at }}>2,5$. Реакция образования 
$\mathrm{Fe}_{2} \mathrm{Al}_{5}$ в 3 раза более предпочтительна, чем реакция (3) образования $\mathrm{FeAl}_{3}$. Одновременно проведен расчет констант устойчивости интерметаллических соединений между компонентами гартцинка. Константа устойчивости при $550^{\circ} \mathrm{C}$ для $\mathrm{Fe}_{2} \mathrm{AI}_{5}$ в 2,0 раза выше, чем для $\mathrm{FeZn}{ }_{10}$, и незначительно (в 0,93 раза) снижается при снижении температуры от 600 до $500^{\circ} \mathrm{C}$. Приведенные результаты предполагают, что в присутствии алюминия в расплавленном цинке железо кристаллизуется в виде $\mathbf{F e}_{2} \mathbf{A I}_{5}$ заменяя $\mathbf{F e Z n _ { 1 0 }}$ по реакции (4.1) и тем самым снижается выход цинка в дроссы [23].

В промышленных условиях для реальной работы оборудования требуется температура ниже $650^{\circ} \mathrm{C}$. В этом диапазоне температур железо в гартцинке кристаллизуется в твердую фазу $\mathrm{FeZn}_{10}$. Высокий выход цинка в дроссы (показатель $\mathrm{Zn} / \mathrm{Fe}$ ) объясняется образованием кристаллов $\mathrm{FeZn}_{10}$ и выход их в отфильтрованные дроссы.

\section{2. Тодщина пденки жидкого цинка на поверхности твердых кристалдов соединений железа}

Снижение выхода цинка в отходы - дроссы можно добиться уменьшением свободного жидкого цинка, не связанного в тугоплавкие кристаллические соединения. Свободный цинк пленкой покрывает поверхность твердых кристаллов. Поэтому представляет интерес оценка величины такой пленки, например измерением удельной поверхности дроссов.

Образец пористых кристаллов дроссов из фильтра содержащих 3,12\% железа, 95,9\% цинка исследован на удельную поверхность методом адсорбции аргона. Удельная поверхность дроссов составила 0,515 м²/г [23].

Для расчета фазового состава примем, что цинк одинаково смачивает кристаллы соединений. Принято, что $3,12 \%$ железа в расплаве связано с цинком в соединение $\mathrm{FeZn}$. Плотность твердых кристаллов

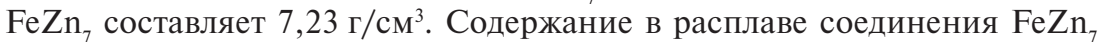
составит $28,7 \%$. В этом случае содержание связанного цинка в расплаве составит 25,6\%. Удельный объем кристаллов $\mathrm{FeZn}$ при его плотно-

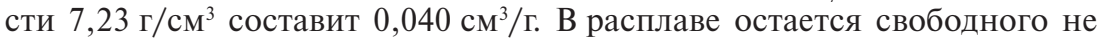
связанного соединения цинка $-71,3 \%$.

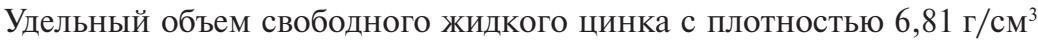
на кристаллах $\mathrm{FeZn}$ составит 0,1 cм $^{3} /$ г. Удельная поверхность кристаллов дроссов определенная методом адсорбции аргона составляет $0,515 \mathrm{~m}^{2} /$ г или $5150 \mathrm{~cm}^{2} /$ г. Исходя из этого расчетная толщина жидкой пленки на поверхности твердых кристаллов составит 0,029 микрон.

Поэтому полагаем, что снижения выхода цинка в дроссы можно достигнуть за счет снижения удельной поверхности кристаллов дроссов, т. е. крупности кристаллов. Кроме того, выход цинка может быть снижен 
при замене соединений железа $\mathrm{FeZn}_{7}$ в дроссах на соединения с алюминием $\mathrm{FeAl}_{2}$ и $\mathrm{Fe}_{2} \mathrm{Al}_{5}$.

Расчетом фазового состава определено, что дроссы состоят из 73,3\% металлического цинка и 25,3\% твердой фазы $\mathrm{FeZn}_{10}$ с плотностью 7,23 см³. По данным удельной поверхности расчетом определено, что толщина пленки жидкого цинка по поверхности кристаллов составляет менее $2 \mu$ (микрон).

Для снижения выхода цинка в дроссы необходимо укрупнение кристаллов кристаллизацией и снижения удельной поверхности частиц сыпучих дроссов. Степень удаления железа центробежной фильтрацией зависит от условий кристаллизации этих соединений из расплава, т.е. условий роста кристаллов этих соединений железа.

Показано, что связывание железа с алюминием в соотношении $(\mathrm{Al} / \mathrm{Fe})_{\text {at }}=0,9-1,6$ железо преимущественно удаляется в виде $\mathrm{AlFe}_{2}$ и снижается выход цинка в дроссы [24]. Измерения удельной поверхности кристаллов дроссов показало, что для снижения выхода цинка в дроссы необходимо укрупнение кристаллов соединений железа кристаллизацией.

\section{3. Исследование фазового состава продуктов фидьтрации гартцинка}

Для снижения выхода цинка в фильтростатки необходимы сведения о фактическом фазовом составе соединений железа в цинке и фильтростатках.

Для исследования фаз продуктов рафинирования гартцинка отобраны пробы взятые при центробежной фильтрации, которые ниже приведены в табл. 13. Пробы образцов анализировалась химическим и атомно адсобционным методом на атомно-эмиссионном спектрометре с индуктивно связанной плазмой IRIS Intrepid компании INTERTECH Corporation.

Фазовый состав некоторых образцов определялся в институе ИХТИМС СО РАН методом РФА на дифрактометре ДРОН-3, с рентгеновской трубкой БСВ с медным анодом. Спектр пробы 5 дроссов изображен на рис. 26.

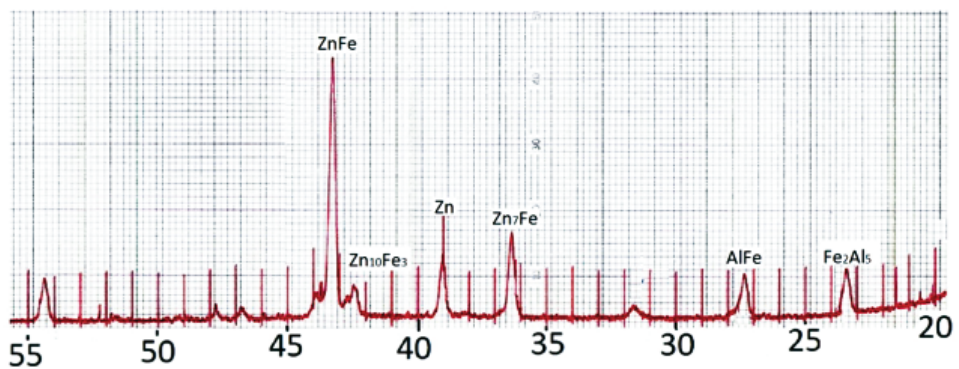

Рис. 26. Рентгенограмма образиа 5 дроссов. Состав образиа 5: $\mathrm{Fe}-10,94 \%$; $\mathrm{Al}-8,7 \%$; остальное $\mathrm{Zn}$ 
Рентгенограмма на рис. 26 показывает, что проба образца 5, (содержащая $\mathrm{Fe}-10,94 ; \mathrm{Al}-8,7)$ отобрана от расплава, в котором реакции взаимодействия алюминия с железом не закончены, так как наряду с кристаллами $\mathrm{Zn}, \mathrm{ZnFe}$ содержат и фазы $\mathrm{AlFe}$ и $\mathrm{Fe}_{2} \mathrm{Al}_{5}$ [25.4].

Кроме того образцы от фильтрации гартцинка в разных условиях исследованы РСМА и ЯГР спектроскопией. При измерении мессбауровских спектров ЯГР железа использовали источник кобальт-57 в матрице палладия. В качестве эталона для калибровки шкалы скоростей и измерения химических сдвигов применяли металлическое железо. На рис. 27. приведены спектры эталонов сплавов железа с алюминием и цинком.

Мессбауэровский спектр сплава желез с цинком (эталон проба 1) при содержании железа $4,37 \%$ являются одиночной линией с химическим сдвигом $0,27 \mathrm{Mм} / \mathrm{c}$ и шириной $0,41 \mathrm{mм} / \mathrm{c}$ (рис. 27). Мессбауэровский спектр эталона (проба 4 железа с алю-

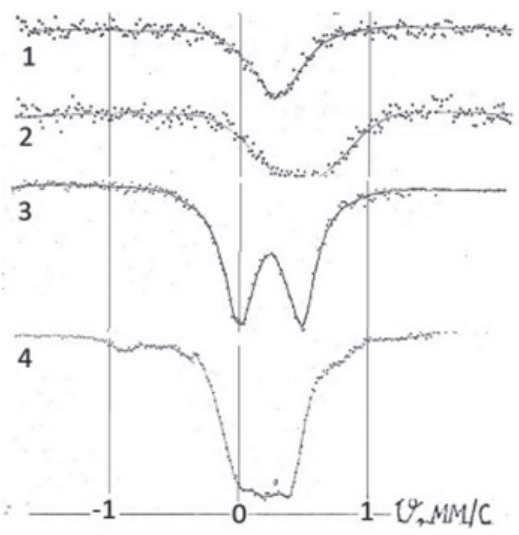

Рис. 27. Сравнение спектра ЯГР дроссов с индивидуальными сплавами.

Пробы образиов: 1 - сплав $\mathrm{Zn}+4,37 \% \mathrm{Fe}$; $\delta=0,27 ; \Gamma=0,41 \mathrm{MM} / \mathrm{c} ; 2-$ дроссы $8,04 \% \mathrm{Fe} ; 0,22 \% \mathrm{Al} ; \delta=0,45 ; \Gamma=0,79 \mathrm{MM} / \mathrm{c}$; 3 - дроссы $11,2 \% \mathrm{Fe} ; 17,36 \% \mathrm{Al} ; \delta=0,5$;

$\Gamma=0,45 \mathrm{mм} / \mathrm{c} ; 4-$ сплав $\mathrm{Al}+11 \% \mathrm{Fe}$; $\delta=0,21 ; \Gamma=0,32 \mathrm{MM} / \mathrm{c}$ минием) при содержании железа в сплаве $10,98 \%$ является суперпозицией квадрупольного дублета с химическим сдвигом $0,21 \mathrm{~mm} / \mathrm{c}$ и квадрупольным расщеплением $0,32 \mathrm{mм} / \mathrm{c}$ и слабоинтенсивных линий, относящихся к магнитной фазе. Мессбауэровские спектры дроссов пробы образца 2 с пренебрежимо малым количеством алюминия является слабоинтенсивным и очень широкими линиями с центром тяжести при $0,45 \mathrm{~mm} / \mathrm{c}$ и шириной $0,79 \mathrm{Mm} / \mathrm{c}$. Это свидетельствует, что в железо-цинковых дроссах присутствует две формы железа разной стехиометрии со связями $\mathrm{Fe}-\mathrm{Zn}$. Спектр дроссов образца 3 является ассиметричными (правая компонента более широкая) квадрупольными дублетами, которые приписываются предварительно соединению $\mathbf{F e A l}_{2}$, со средним значением химического сдвига и квадрупольного расщепления 0,5 и 0,45 мм/с, что свидетельствует о существовании двух состояний железа. 
Для уточнения указанных положений о составе фаз пробы фильтрации исследованы методом РСМА. Часть образцов сыпучих дроссов заливали сплавом Вуда и готовили шлифы в институте геологии СО РАН. Шлифы проб исследованы в ИНХ СО РАН методом РСМА на спектрометре Camebax SX-50 (фирмы CAMECA) с растровым электронным микроскопом и рентгеновским микроанализатором. Диаметр зонта 0,2-0,3 мкм в стандартном режиме с ускоряющим напряжением $15 \mathrm{KV}$ и током $40 \mathrm{~mA}$. Шаг перемещения образца 1 мкм. В качестве эталонов использованы чистые металлы. Микрозонодовое сканирование выполнено пакетом ADV_CIPP Фирмы CAMECA. Файлы фото получены с помощью оригинальной программы визуализации данных микрозондового сканирования (автор В. Перевозкин) [26].

В табл. 13 приведены данные количественного анализа выполненные для трех элементов: $\mathrm{Zn}, \mathrm{Fe}, \mathrm{Al}$. Измерения распределения элементов по поверхности дают схожие результаты по концентрации цинка от 96 до 97,5\%. Под оптическим микроскопом это голубоватая поверхность цинка с вкраплением серых выпуклых частиц неправильной формы размерами 5-50 мкм. Состав частиц практически одинаков и соответствует $F e A 1_{(2,1-2,4)}[27]$.

Таблица 13

Сравнение анализов образцов с исследованием РСМА твердых фаз

\begin{tabular}{|c|c|c|c|c|c|c|c|}
\hline $\begin{array}{l}\text { Номер } \\
\text { проб }\end{array}$ & Характеристика участка & $\mathrm{Fe}$ & $\mathrm{Zn}$ & $\mathrm{Al}$ & $\mathrm{Al} / \mathrm{Fe}$ & $\mathrm{Zn} / \mathrm{Fe}$ & Фаза \\
\hline 1 & 2 & 3 & 4 & 5 & 6 & 7 & 8 \\
\hline \multirow{7}{*}{$T=\stackrel{6}{530^{\circ} \mathrm{C}}$} & $\begin{array}{l}\text { Анализ исходного метал- } \\
\text { ла, вес, \% } \\
\end{array}$ & 6,7 & 87,4 & 5,85 & 0,87 & & \\
\hline & атом \% & 7,19 & 79,9 & 12,88 & 1,78 & & \\
\hline & поверхность & 4,5 & 75,7 & 19,8 & 4,4 & 16,8 & \\
\hline & Кристалл 1 & 25,7 & 13,6 & 63,8 & 2,48 & 0,53 & $\mathrm{Fe}_{2} \mathrm{Al}_{5} \cdot \mathrm{Zn}_{0,5}$ \\
\hline & Кристаллы 2,3 & 26,7 & 12,6 & 59,5 & 2,23 & 0,47 & $\mathrm{FeAl}_{2,2} \cdot \mathrm{Zn}_{0,5}$ \\
\hline & Кристалл 4 & 4,3 & 86,9 & 5,5 & 1,28 & 20,2 & $\mathrm{FeAl}_{1,3}$ \\
\hline & Кристаллы 5,6 30 мкм & 27,7 & 11,4 & 58,8 & 2,12 & 0,41 & $\mathrm{FeAl}_{2,3} \cdot \mathrm{Zn}_{0,5}$ \\
\hline \multirow{4}{*}{$T=\stackrel{7}{480^{\circ} \mathrm{C}}$} & Анализ брызг вес, \% & 0,12 & 99,6 & 0,28 & 2,33 & & \\
\hline & атом, $\%$ & 0,14 & 99,2 & 0,67 & 4,82 & & \\
\hline & Кристалл 1 & 26,9 & 11,5 & 62,7 & 2,33 & 0,43 & $\mathrm{FeAl}_{2,3} \cdot \mathrm{Zn}_{0,5}$ \\
\hline & Кристалл 2 & 26,6 & 11,9 & 64,3 & 2,42 & 0,45 & $\mathrm{FeAl}_{2,4} \cdot \mathrm{Zn}_{0,5}$ \\
\hline
\end{tabular}


Окончание табл. 13

\begin{tabular}{|c|c|c|c|c|c|c|c|}
\hline 1 & 2 & 3 & 4 & 5 & 6 & 7 & 8 \\
\hline \multirow{5}{*}{$T=\stackrel{8}{480^{\circ} \mathrm{C}}$} & Анализ металла, вес, \% & 1,65 & 96,5 & 1,85 & 1,12 & & \\
\hline & атом, $\%$ & 1,87 & 93,8 & 4,33 & 2,31 & & \\
\hline & Кристалл 1 & 27,5 & 12,3 & 61,9 & 2,25 & 0,45 & $\mathrm{Fe}_{2} \mathrm{Al}_{5} \cdot \mathrm{Zn}_{0,5}$ \\
\hline & поверхность $\mathrm{Zn}$ & 0,2 & 97,3 & 0,5 & 2,5 & 487 & $\mathrm{Fe}_{2} \mathrm{Al}_{5}$ \\
\hline & Кристалл 2 & 27,3 & 12,1 & 60,6 & 2,22 & 0,44 & $\mathrm{Fe}_{2} \mathrm{Al}_{5} \cdot \mathrm{Zn}_{0,5}$ \\
\hline \multirow{7}{*}{$\begin{array}{c}9 \\
T=490^{\circ} \mathrm{C}\end{array}$} & Анализ пены вес, \% & 2 & 96,4 & 1,63 & 0,82 & & \\
\hline & атом, $\%$ & 2,27 & 93,9 & 3,82 & 1,68 & & \\
\hline & поверхность $\mathrm{Zn}-1,2,3$ & 8,1 & 84,5 & 5,1 & 0,63 & 10,4 & $\mathrm{FeZn}_{10}$ \\
\hline & Кристалл 5 & 27,5 & 13,5 & 59,3 & 2,16 & 0,49 & $\mathrm{FeAl}_{2,2} \cdot \mathrm{Zn}_{0,5}$ \\
\hline & поверхность Zn 4,5 & 7,9 & 85,5 & 5,1 & 0,65 & 10,8 & $\mathrm{FeZn}_{11}$ \\
\hline & Кристалл 6 & 27,6 & 12,8 & 59 & 2,14 & 0,46 & $\mathrm{FeAl}_{2,1} \cdot \mathrm{Zn}_{0,5}$ \\
\hline & Кристалл 7,8 & 27 & 12,6 & 61,9 & 2,29 & 0,47 & $\mathrm{FeAl}_{2,3} \cdot \mathrm{Zn}_{0,5}$ \\
\hline \multirow{7}{*}{$T=480^{\circ} \mathrm{C}$} & Анализ дроссов вес, \% & 2,81 & 95 & 2,24 & 0,8 & & \\
\hline & атом, $\%$ & 3,16 & 91,6 & 5,2 & 1,64 & & \\
\hline & поверхность Zn 1 & 8,5 & 86,9 & 3,8 & 0,45 & 10,2 & $\mathrm{FeZn}_{10}$ \\
\hline & Кристалл 3 & 29,1 & 11,8 & 55,6 & 1,91 & 0,41 & $\mathrm{FeAl}{ }_{2} \cdot \mathrm{Zn}_{0,5}$ \\
\hline & поверхность Zn 2 & 7,9 & 86,1 & 4,2 & 0,53 & 10,9 & $\mathrm{FeZn}_{11}$ \\
\hline & Кристалл 4,5 & 26,6 & 11,9 & 58,6 & 2,2 & 0,45 & $\mathrm{FeAl}_{2,2} \cdot \mathrm{Zn}_{0,5}$ \\
\hline & Кристалл 6,7 & 21,4 & 27,7 & 49,5 & 2,31 & 1,29 & $\mathrm{FeAl}_{2,3} \cdot \mathrm{Zn}_{0,5}$ \\
\hline
\end{tabular}

Примечание: пробы сыпучих дроссов заливали расплавом Вуда для шлифовки образцов.

Сравнение исходных анализов образцов, приведенных в табл. 13, с результатами исследования состава фаз в этих образцах показывает, что фазовый состав более разнообразней, чем термодинамически предполагалось в первом разделе главы.

В исходном металле проба 6 с $\mathrm{Fe}-6,7 \%$ на основном поле исходного металла с кристаллами $\mathrm{FeZn} \mathrm{Z}_{10}$ наблюдаются кристаллы не только состава $\mathrm{Fe}_{2} \mathrm{Al}_{5} \cdot \mathrm{Zn}_{0,5}$, но и составов $\mathrm{FeAl}_{(2,2-2,3)} \cdot \mathrm{Zn}_{0,5}$ и $\mathrm{FeAl}_{1,3}$. 
По ходу фильтрации металла при $T=480^{\circ} \mathrm{C}$ с промежуточным содержанием в ванне $\mathrm{Fe}-1,8 \%$ отобрана проба 7 брызг металла из фильтра, которая содержала $\mathrm{Fe}=0,12 \%$ в форме $\mathrm{FeAl}_{(2,3-2,4)} \cdot \mathrm{Zn}_{0,5}$. В то время как проба 8 показала, что в ванне осталось $1,65 \% \mathrm{Fe} \mathrm{в} \mathrm{форме} \mathrm{Fe}_{2} \mathrm{Al}_{5}$.

В течение фильтрации металла при $T=490^{\circ} \mathrm{C}$ с содержанием $3 \% \mathrm{Fe}$ на поверхности металла скапливается пена (проба 9), содержащая $2 \% \mathrm{Fe}$ с соотношением $\mathrm{Al} / \mathrm{Fe}=1,65$, в которой железо в основном в форме $\mathrm{FeZn} \mathrm{n}_{(10-11)}$ с кристаллами $\mathrm{FeAl}_{(2,1-2,3)} \cdot \mathrm{Zn}_{0,5}$.

В пробе 10 дроссов из фильтра от фильтрации металла при $T=480^{\circ} \mathrm{C}$ с содержанием $\mathrm{Fe}=0,6 \%$, содержится $2,81 \% \mathrm{Fe}$, в форме $\mathrm{FeAl}_{2,3} \cdot \mathrm{Zn}_{0,5}$, и $\mathrm{FeAl} \cdot \mathrm{Zn}_{0,5}$, но в дроссах содержится и фаза $\mathrm{FeZn} \mathrm{Z}_{10}$.

На рис. 28 представлено изображение участка поверхности образца 11 на основе регистрации сигнала отраженных электронов в виде сине-фиолетовых частиц фазы $\mathrm{Fe}-\mathrm{A} 1$.

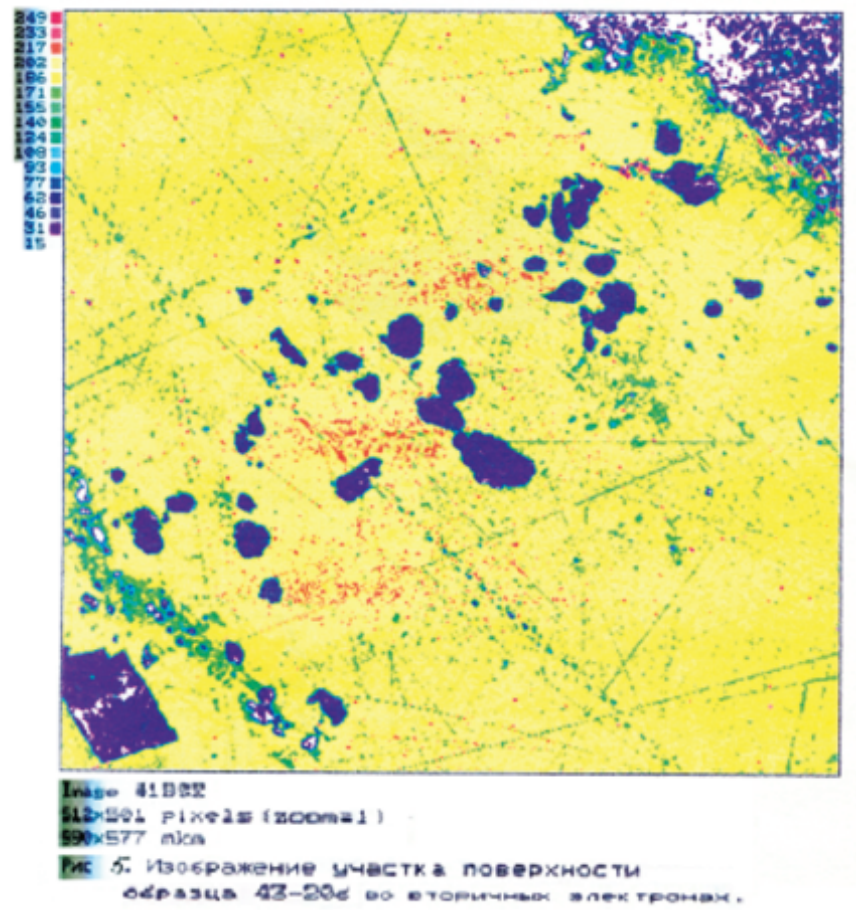

Рис. 28. Фото участка поверхности образиа 11 
На рис. 28 фото шлифа пробы 11 в окне на фоне множества красных точек $\mathrm{FeZn}$ и коричневых точек FeAl можно выделить более крупные кристаллы FeAl.

Таблица 14

Структура диссперсности фаз поля шлифа образца 11

\begin{tabular}{|c|c|c|c|c|c|}
\hline Штук & Размер, мм & мкм & $S$, мкм $^{2}$ & $S$ sum & Доля, $\%$ \\
\hline 18 & $<4$ & 15 & 175 & 3159 & 29,1 \\
\hline 11 & $4-6$ & 23 & 413 & 4539 & 41,8 \\
\hline 2 & $6-12$ & 45 & 1579 & 3159 & 29,1 \\
\hline
\end{tabular}

На поле фазы $\mathrm{FeZn}$ 10 отмечается высокая доля 70,9\% фракций менее 23 мкм фаз соединений $\mathrm{Fe}_{2} \mathrm{Al}_{5} \cdot \mathrm{Zn}_{0,5}, \mathrm{FeAl}_{1,3}, \mathrm{FeAl}_{(2,1-2,3)} \cdot \mathrm{Zn}_{0,5}$.

\section{4. Изменение фаз после кристалдизации расплава}

Фильтрация гартцинка с алюминием позволяет связать железо с алюминием с высокой долей мелких дисперсных фаз. Для кристаллизации соединений расплав с температурой $600^{\circ} \mathrm{C}$ охлаждался до температуры фильтрации $460^{\circ} \mathrm{C}$ в течение 2 часов.

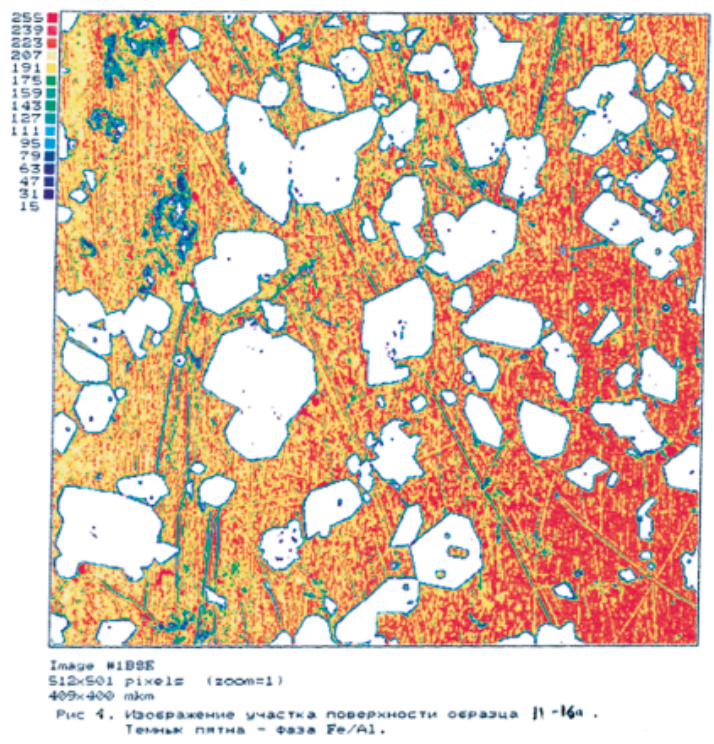

Рис. 29. Фото участка поверхности образиа 12 дроссов 
На рис. 29 представлено изображение участка поверхности образца 12 на основе регистрации сигнала отраженных электронов (BSE). Hе закрашенные участки соответствуют темной области на электронном микроскопе и являются фазой $\mathrm{Fe} \sim \mathrm{A} 1$.

На рис. 29 фото шлифа пробы 12 на фоне множества красных точек $\mathrm{FeZn}$ можно выделить более крупные кристаллы белого цвета FeAl.

Таблица 15

Структура дисперсности поля шлифа образца 12

\begin{tabular}{|c|c|c|c|c|c|}
\hline Штук & Размер, мм & мкм & $S$, мкм $^{2}$ & Ssum & Доля, $\%$ \\
\hline 60 & $<4$ & 10 & 78 & 4710 & 8,9 \\
\hline 29 & $4-7$ & 18 & 252,7 & 7328 & 13,8 \\
\hline 18 & $7-14$ & 37 & 1068 & 19221 & 36,3 \\
\hline 6 & $14-26$ & 68 & 3607 & 21640 & 40,9 \\
\hline & & & sum & 52899 & 100 \\
\hline
\end{tabular}

В сечении зафиксирована основная доля 40,9\% фаз FeA1 размером 14-26 мкм (табл. 15) на фоне многочисленных фаз размером $<18$ мкм. Доля мелких фракций (меньше 18 мкм) составил менее 22\%. Укрупнение частиц произошло, но недостаточно.

Таблица 16 Характеристика пробы образца 11 металла

\begin{tabular}{|c|c|c|c|c|c|c|c|}
\hline \multirow{8}{*}{$T=600-460^{\circ} \mathrm{C}$} & Характеристика & $\mathrm{Fe}$ & $\mathrm{Zn}$ & $\mathrm{Al}$ & $\mathrm{Al} / \mathrm{Fe}$ & $\mathrm{Zn} / \mathrm{Fe}$ & Фаза \\
\hline & Анализ, вес, \% & 1,41 & 97,2 & 1,35 & 0,96 & & \\
\hline & Атом, $\%$ & 1,61 & 95,2 & 3,18 & 1,97 & & \\
\hline & Поверхности Zn 1, 2 & 8,1 & 87,1 & 4,2 & 0,5 & 11 & FeZn11 \\
\hline & Кристалл 3 & 25,7 & 13,9 & 61,6 & 2,4 & 0,5 & $\mathrm{Fe}_{2} \mathrm{Al}_{5} \cdot \mathrm{Zn}_{0,5}$ \\
\hline & Кристаллы 4, 5, 6 & 25,9 & 14 & 60,8 & 2,3 & 0,5 & $\mathrm{FeAl}_{2,3} \cdot \mathrm{Zn}_{0,5}$ \\
\hline & Кристаллы 7, 8 & 26,4 & 14,3 & 59 & 2,2 & 0,5 & $\mathrm{FeAl}_{2,2} \cdot \mathrm{Zn}_{0,5}$ \\
\hline & Кристаллы 9, 10, 11, 12 & 43,5 & 2,4 & 47,9 & 1,1 & 0,1 & $\mathrm{FeAl}$ \\
\hline
\end{tabular}

Таблица 16 показывает, что на относительно чистой поверхности цинка с концентрацией $98 \%$, зарегистрированы кристаллы $\mathrm{FeAl}_{0,5}$. 
Кроме обычных серых частиц фазы $\mathrm{FeAl}_{(2,2-2,4)}$ обнаружена фаза FeA1. Некоторые частицы были композитными, т. е. состояли из двух фаз.

Карты распределения $\mathrm{Fe}, \mathrm{Al}, \mathrm{Zn}$ для нижней из группы трех частиц в центре представлены на рис. 30. Карты построенные на основе регистрации соответствующих рентгеновских линий: $\mathrm{Fe}_{\text {Ка }}, \mathrm{Al}_{\mathrm{Ka}}, \mathrm{Zn}_{\mathrm{La}}$.

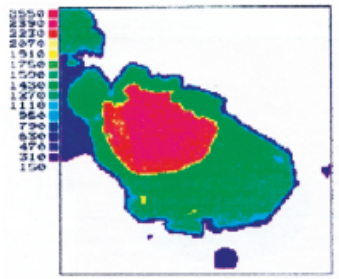

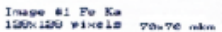

$\mathrm{Fe}$

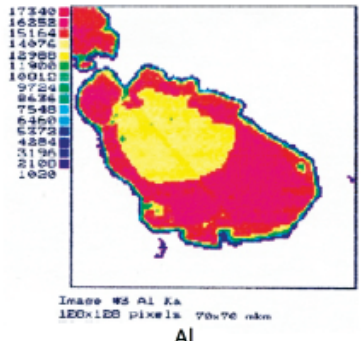

Al

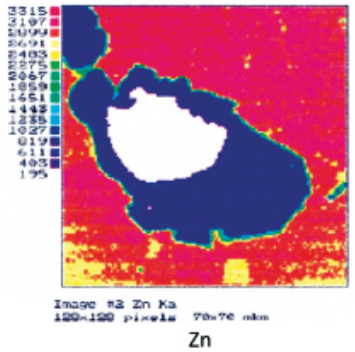

$\mathrm{Zn}$

Рис. 30. Распределения Fe, $\mathrm{Al}$, Zn по поверхности образиа 11.

Шкала соответствия числа зарегистрированных импульсов (верхний предел) в цвете. Размер изображенного участка в микронах $(X \times Y)$

Как видно из рис. 30 в основной массе частицы фазы FeA1 2 , присутствует $14 \%$ цинка, а в центральном пятне фазы FeA1 цинка практически нет.

Это можно объяснить тем, что реакция $\mathrm{FeZn} \mathrm{c} \mathrm{Al} \mathrm{не} \mathrm{завершилась,}$ так как вероятно длительность 1,5 часа охлаждения от 600 до $460^{\circ} \mathrm{C}$ недостаточна. Отмечен факт неоднородности распределения элементов в твердой фазе частиц.

Обнаружено отклонение от термодинамического прогноза и вскрыта не стехиометрическое соотношение элементов в кристаллах соединений железа. Поэтому представляется интересным в дальнейшем рассмотреть методом РСМА распределение элементов по поверхности кристаллов в процессе достижения равновесного состояния.

\section{5. Распределение элементов по поверхности твердого кристалда}

Из исходного металла с $2,88 \% \mathrm{Fe}$ при температуре $T=460{ }^{\circ} \mathrm{C}$ в процессе фильтрации отобрана проба 12 дроссов, содержащая $\mathrm{Fe}-1,7 \%$ с соотношением $\mathrm{Al} / \mathrm{Feat}=0,63$.

Для отдельных частиц шлифа дроссов, построена карта распределения элементов $\mathbf{F e}, \mathbf{A l}, \mathbf{Z n}$ по поверхности частицы. Карты построенные на основе регистрации соответствующих рентгеновских линий: $\mathrm{Fe}_{\mathrm{Ka}}, \mathrm{Al}_{\mathrm{Ka}}, \mathrm{Zn}_{\mathrm{La}}$, и $\mathrm{Fe}$ с A1. Шлиф образца 12 дроссов (рис. 31) исследован под растровым электронным микроскопом методом РСМА на количественный анализ и элементов: Fe, Al, Zn. 


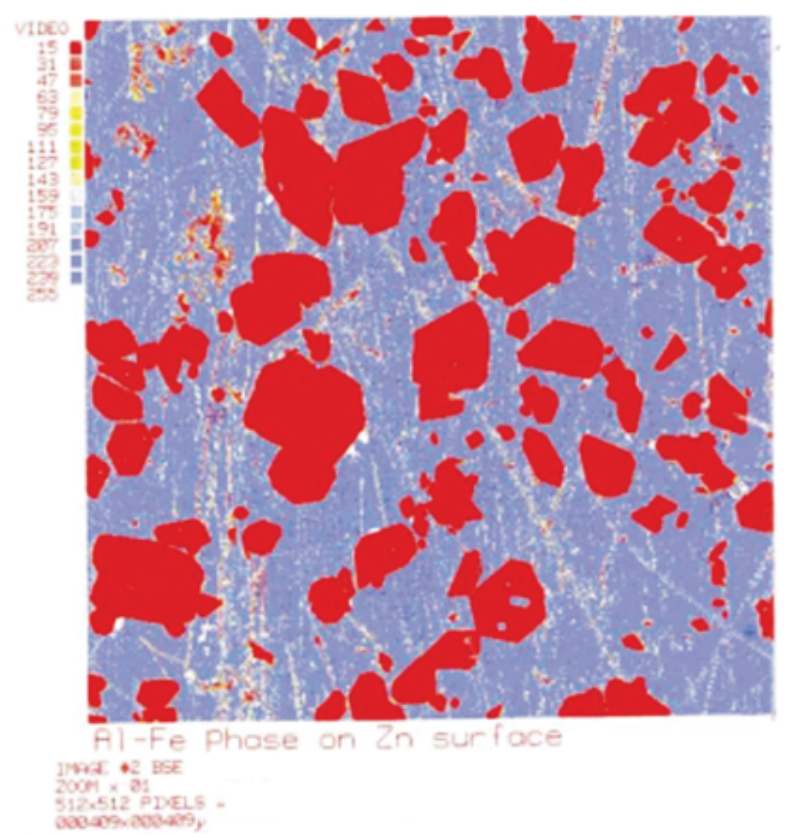

Pис. 31. Распределение фаз FeAl на поверхности цинка образиа 12

Слева от изображения приведена шкала соответствия числа зарегистрированных импульсов раскрашенный соответствующим цветом. Размер изображенного участка в микронах $(X \times Y)$.

На фото рис. 32 в цвете представлены карты распределения $\mathrm{Fe}, \mathrm{Al}$, $\mathrm{Zn}$ двухмерных массивов микрозондового сканирования фрагмента поверхности образца 12.
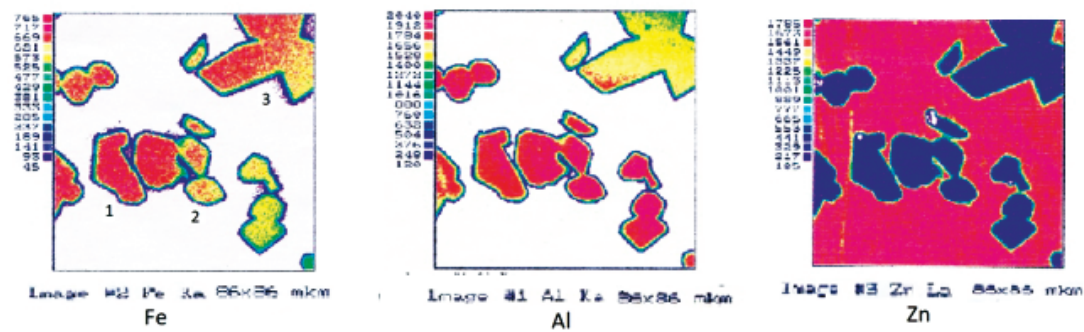

Рис. 32. Фото фрагментов поверхности кристаллов образиа 12 
Распределения Fe и A1 имеют различия. Так «трилистник» в верхнем правом углу содержит меньше алюминия, а частицы в правом нижнем наоборот - с пониженным содержанием железа.

Выбранный кристалл неправильной формы со средним размером 17 мкм. Кристаллы покрыты пленкой 1,9 мкм почти такого же состава, но с менее четкими импульсами Fe. По расчетам импульсов элементов кристалл 1 имеет состав: $\mathrm{Fe}-25 ; \mathrm{Al}-75 \%$ at; $\mathrm{Al} / \mathrm{Fe}=3$. Имеется кристалл 2 с малонасыщенным импульсами $\mathrm{Fe}$, но такого же состава. Имеется кристалл 3 с разной мало насыщенностью импульсов $\mathrm{Fe}$ в разных частях, но такого же состава.

Факт разной насыщенности импульсов Fе на поверхности кристалла исследован построением карты распределения элементов по поверхности кристалла. В процессе фильтрации металла с содержанием $0,66 \% \mathrm{Fe}$ при температуре $T=500^{\circ} \mathrm{C}$ отобрана проба 13 дроссов из тарелей фильтра в виде клина (табл. 17).

Таблица 17

Характеристика образца 13 дроссов

\begin{tabular}{|c|l|c|c|c|c|c|c|}
\hline \multirow{2}{No}{ п/п } & Характеристика участка & $\mathrm{Fe}$ & $\mathrm{Zn}$ & $\mathrm{Al}$ & $\mathrm{Al} / \mathrm{Fe}$ & $\mathrm{Zn} / \mathrm{Fe}$ & Фаза \\
\hline \multirow{4}{*}{$\begin{array}{c}13 \\
T_{\phi}=50{ }^{\circ} \mathrm{C}\end{array}$} & Анализ дроссов, вес, $\%$ & 4,2 & 94,8 & 0,96 & 0,23 & \multicolumn{3}{|c|}{} \\
\cline { 2 - 9 } & Атом, \% & 4,79 & 92,9 & 2,29 & 0,48 & \multicolumn{3}{|c|}{} \\
\cline { 2 - 9 } & поверхность 1 & 6,6 & 82,2 & 1,8 & 0,27 & 12,4 & $\mathrm{FeZn}_{10}$ \\
\cline { 2 - 9 } & кристалл 1 & 62,4 & 2,4 & 40 & 0,64 & 0,04 & $\mathrm{Fe}_{2} \mathrm{Al}$ \\
\hline
\end{tabular}

Для образца со средним содержанием (\% вес) железа $-4,2$, алюминия - 0,96 выполнялся методом РСМА количественный анализ в отдельно выбранных точках (размером 2-3 мм) и построена (рис. 33) карта распределения трех элементов: $\mathrm{Fe}, \mathrm{Al}, \mathrm{Zn}$.

На участках шлифа с кристаллом FeAl (преимущественного содержания железа кристалл содержал $62,4 \%$ железа, алюминия $30 \% \mathrm{Al}$ и цинка $2,4 \% \mathrm{Zn}$. Это свидетельствует о том, что железо связано с алюминием.

Для образца 13 выполнялся количественный анализ методом РСМА в отдельно выбранных точках (размером 2-3 мм) и построена карта распределения трех элементов: $\mathrm{Fe}, \mathrm{Al}, \mathrm{Zn}$ на содержание цинка, железа, алюминия (рис. 33).

На участках преимущественного содержания синего фона цинка $82,16 \%$. содержание железа составляет $6,6 \% \mathrm{Fe}$, а алюминия $1,8 \% \mathrm{Al}$. 


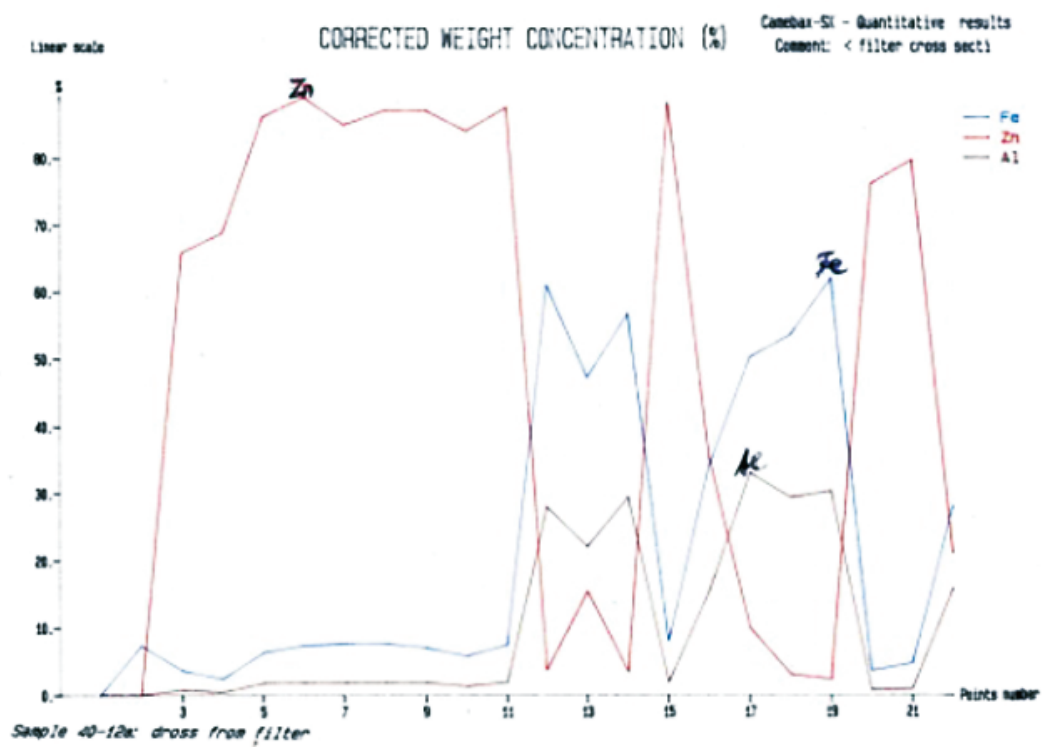

Рис. 33. Карта распределения элементов $\mathrm{Fe}, \mathrm{Al}$, Zn по поверхности образиа 13

На участках шлифа с преимущественным содержанием железа $62,4 \%$ и содержанием алюминия составляет $30 \%$ и цинка 2,4\% наблюдается в основном фаза железа в виде кристаллов $\mathbf{F e A l}_{2}$ по виду как выпуклые капли с металлическим блеском размером по 100 мкм. На некоторых участках шлифа с содержанием 43,5-50 ат\% железа (красные участки) содержание алюминия составляло 46-47,9 ат\% содержится в виде фаза FeAl в виде плоских частиц желтоватого цвета, размером 10-50 мкм, с соотношением $(\mathrm{Al} / \mathrm{Fe})_{\text {at }}=1,1$. На фоне кристаллов переменного состава от $\mathrm{FeZn}_{7}$ до $\mathrm{FeZn} \mathrm{n}_{10}$ наблюдается третья фаза железа $\mathrm{Fe}_{2} \mathrm{Al}_{5}$ соотношением $(\mathrm{Al} / \mathrm{Fe})_{\text {at }}=2,3$.

Исследование продуктов фильтрации показали [26], что железо в гартцинке содержится в виде кристаллов $\mathrm{FeZn}_{7}$ и $\mathrm{FeZn}_{10}$, а отделяется железо в фильтростатки в основном в виде кристаллов $\mathrm{FeAl}_{2}$.

\section{6. Окисленность кристалдов}

Опытами показано, что частичное окисление дроссов снижает смачиваемость кристаллов цинком и снизить выход цинка в отходы дроссы.

Для исследования окисленности поверхности кристаллов в поле образца 11 с $\mathrm{Fe}-2,18$ и $(\mathrm{Al} / \mathrm{Fe})_{\text {at }}=1,98$ выбран кристалла $\mathrm{FeAl}_{2}$ размером 
44 мкм и методом PCMA измерены концентрации $\mathrm{Fe}, \mathrm{Al}$, кислорода вдоль пересекающей частицу прямой.

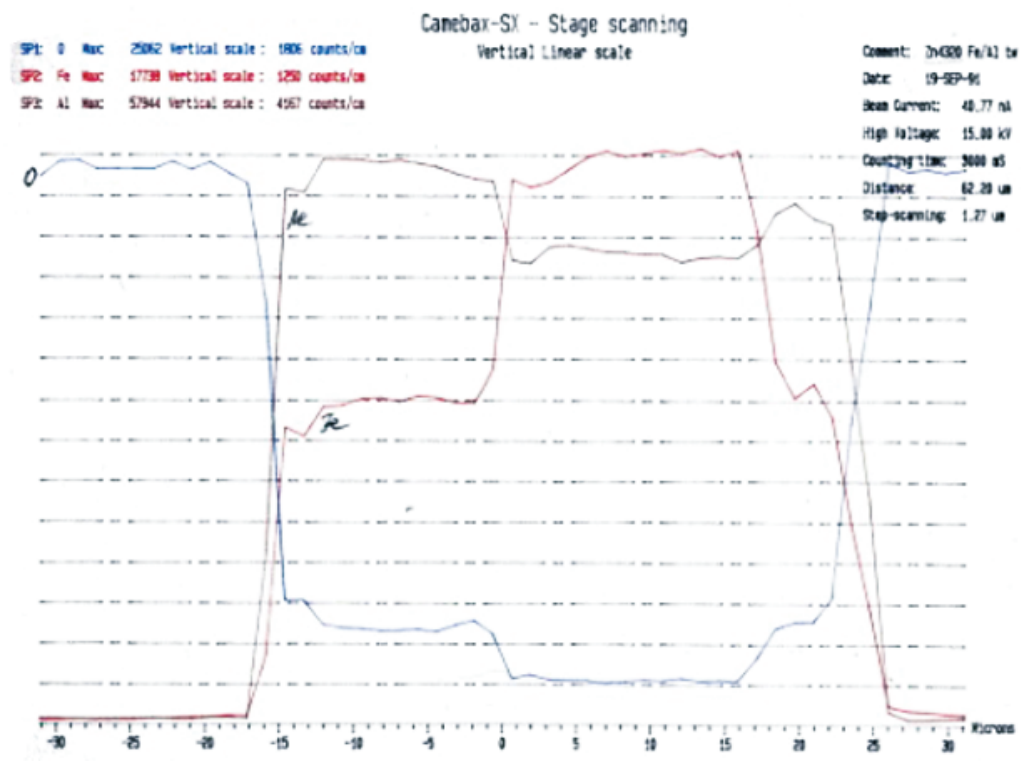

Рис. 34. Карта распределения элементов по сечению кристалла образиа 11. Абсцисса - microns; ордината: $O_{\max }-25062$ - шкала 1806 count/cm; $\mathrm{Fe}_{\max }-17738$ шкала - $1250 \mathrm{count} / \mathrm{cm} ; \mathrm{Al}_{\max }-57944$ - шкала $-4167 \mathrm{count} / \mathrm{cm}$.

По расчету импульсов концентрация кислорода в слое $13,87 \%$. Причем, в центре кристалл имеет состав FeAl. Слева кристалла слоем в 15 микрон имеет состав $\mathrm{Fe}_{2} \mathrm{Al}_{5}$. Справа в координате слоем в 7 микрон кристалл имеет также состав $\mathrm{Fe}_{2} \mathrm{Al}_{5}$ [27].

Минимальная толщина пленки алюминия по кристаллу $\mathrm{FeAl}_{2}$ coставляет 1,4 микрон, а максимальная 1,7 микрон (рис. 34). Максимальная концентрация кислорода на кристалле $\mathrm{FeAl}$ составляла 15,6\% $\mathrm{O}_{2}$. Концентрация при счете импульсов $13,87 \% \mathrm{O}_{2}$ [26].

Это показывает, что кристалл $\mathrm{FeAl}_{2}$ покрыт пленкой алюминия толщиной 1,4-1,7 микрон. Одновременно, кристалл покрыт пленкой кислорода толщиной 2,2 микрон, т. е. окислилась не только пленка алюминия, но и поверхность кристалла $\mathrm{FeAl}_{2}$. При перемешивании расплава мелкодисперсные кристаллы $\mathrm{FeAl}_{2}$ окисляются с поверхности, а окисленные кристаллы плохо смачиваются цинком и всплывают на поверхность расплава в виде пены. 
В целом полученные результаты согласуются с ранее описанными [23] результатами полупромышленных испытаний переработки гартцинка центробежной фильтрацией на промышленной центрифуге ПАВФС 650 с погружным фильтром [26].

\section{7. Распределение размеров частиц соединений в дроссах фильтра}

Для исследования распределения частиц фазовых соединений железа по дисперсности в дроссах собранных полости фильтра (рис. 35) приготовлен образец по описанной методике.

При подъеме вращающегося фильтра из расплава фильтростаток в полости фильтра очищался от остатков жидкого цинка под действием центробежных сил. Дроссы из фильтра не выбрасывались под действием центробежных сил, а фильтр останавливался, охлаждался и из фильтра извлекался брикет спрессованных дроссов.
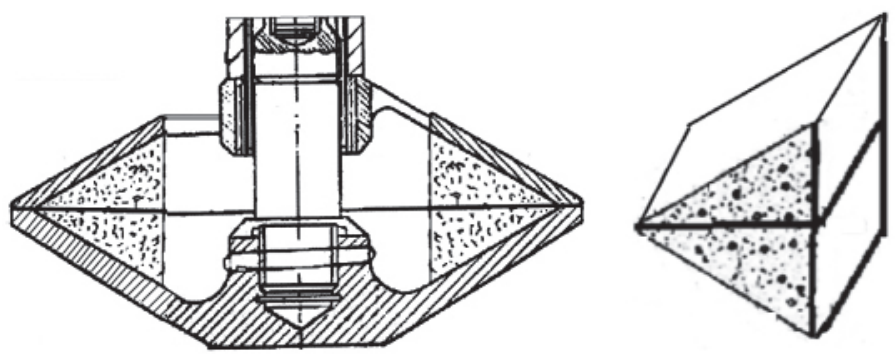

Рис. 35. Отбор пробы 13 дроссов кристаллов соединений железа собранных в фильтре

Из разреза образца 13 дроссов, взятого из полости фильтра (рис. 35) в виде клина, изготовлен шлиф пробы по сечению от фильтрующей щели к центру.

В режиме отраженных электронов получены снимки шлифа клина для построения карты (табл. 18.) распределения частиц по размерам (средний диаметр) [26].

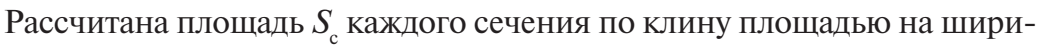
ну клина углом 60 град и 1 см толщиной максимальной частицы 36 мкм.

Рассчитана сумма площадей частиц $S_{s}$ в этом сечении.

По мере удаления от щели фильтра увеличивается доля более мелких кристаллов по уравнению регрессии:

$$
m=19,7-1,46 \cdot z \text { с коэффициентом корреляции } 0,88 \text {, }
$$

где $z$ - расстояние от фильтровальной щели к центру, мм; $m$ - доля кристаллов с указанным диаметром частиц, мкм. 
Таблица 18

Размеры частиц в фильтр-остатке виде клина из тарели

\begin{tabular}{|c|c|c|c|c|c|c|c|c|c|c|}
\hline $\begin{array}{c}R \text { на клине от оси } \\
\text { фильтра, мм }\end{array}$ & \multicolumn{8}{|c|}{ Диаметры частиц, мкм } & $d_{\mathrm{cp}}, \mathrm{MKM}$ & 10-доля, \% \\
\hline 0,2 & 27 & 12 & 15 & 36 & 29 & 10 & 10 & 12 & 19 & 26,4 \\
\hline 1 & 8 & 16 & 8 & 13 & 6 & 7 & 14 & 6 & 10 & 1,5 \\
\hline 2 & 8 & 7 & 8 & 12 & 20 & 10 & 10 & 6 & 10 & 0,8 \\
\hline 3 & 22 & 9 & 12 & 17 & 9 & 13 & 10 & 20 & 14 & 0,8 \\
\hline 4 & 19 & 10 & 10 & 6 & 6 & 12 & 10 & 6 & 10 & 0,3 \\
\hline 6 & 9 & 24 & 10 & 9 & 15 & 7 & 18 & 6 & 12 & 0,4 \\
\hline 8 & 11 & 7 & 12 & 5 & 5 & 13 & 9 & 10 & 9 & 0,1 \\
\hline 10 & 15 & 25 & 20 & 16 & 6 & 1 & 22 & 13 & 15 & 0,4 \\
\hline 12 & 11 & 11 & 17 & 7 & 8 & 13 & 19 & 10 & 12 & 0,2 \\
\hline 15 & 10 & 14 & 15 & 14 & 11 & 16 & 18 & 19 & 15 & 0,2 \\
\hline
\end{tabular}

В фильтре задерживаются частицы 5-36 мкм, которые меньше размером щели 50 мкм. Отсюда следует, что расплавленный цинк циркулирует через фильтр, заполняет фильтрующую щель крупными кристаллами, которые обеспечивают удержанию частиц значительно более мелких, чем размер фильтрующей щели. Кристаллы образуют у щели конгломераты между собой и задерживаются в конусе фильтрующей щели.

Показано распределение размеров частиц в щели фильтра и выявлена способность фильтра задерживать частиц размером меньше размера щели [4].

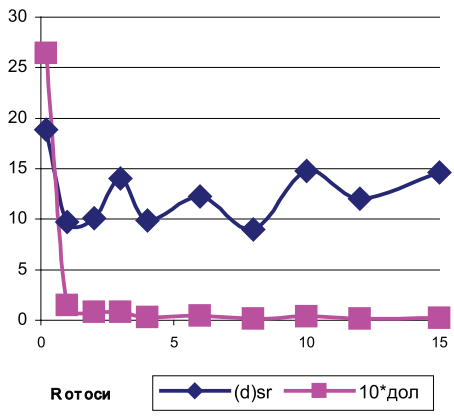

Рис. 36. Распределение д частии, по сечению клина на расстоянии $R$ от оси фильтра.

По абсииссе - R от оси фильтра, в мм; по ординате - $d_{c p}$ частии, в мкм, и 10·долей, \% общей площади частии в поле сечения 


\section{Выводы}

1. Анализы металла и дроссов методами РСМА и Мессбауэровской спектроскопией показана отделение железа в дроссы в виде кристаллов $\mathrm{FeAl}_{2}$ из металла содержащем железо в виде кристаллов $\mathrm{FeZn} \mathrm{Z}_{7}$ и $\mathrm{FeZn}{ }_{10}$

2. Показано,что кристаллизация соединений железа охлаждением способствует увеличению доли крупных кристаллов до $49 \%$

3. Показано, что кристалл $\mathrm{FeAl}_{2}$ покрыт пленкой алюминия толщиной 1,4-1,7 микрон. В то время как минимальная толщина кислородной пленки на кристалле $\mathrm{FeAl}$ составляет 2,2 микрон с концентрацией кислорода $13,87 \% \mathrm{O}_{2}$.

4. Показано распределение размера частиц в фильтре и выявлена способность фильтра задерживать частиц размером меньше размера щели. 


\section{ГДава 5. ТЕХНОЯОГИЯ ЦЕНТРОБЕЖНОЙ ФИЛЬТРАЦИИ ЖЕЛЕЗИСТОГО ЦИНКА}

Производство цинка в основном основано на гидрометаллургическом разложении сырья и электролитического осаждении его из растворов. По этой технологии цинк содержит железа менее $0,0003 \%$ и другие примеси растворимые в цинке. Только на отдельных заводах используют электротермическую плавку цинкового сырья.

По электротермической технологии переработки цинкового сырья Беловского цинкового завода получается черновой цинк с содержанием железа $0,2-0,4 \%$, который удаляется ликвационным рафинированием. Поэтому предпринимались работы по усовершенствованию ликвационного процесса [28]. Авторы в черновой цинк, с содержанием $0,28 \% \mathrm{Fe}$, вмешивали при температуре $560^{\circ} \mathrm{C}$ алюминий с расходом $\mathrm{Al} / \mathrm{Fe}=0,8-1$ с отстоем металла под слоем карналлита с расходом $0,2 \%$ и снимали съемы. Содержание железа в рафинированном цинке $0,04-0,06 \%$, а в съемах содержание железа составляло 4-6\%.

Минцветмет предложил проверить рафинирование электротермического цинка от железа центробежной фильтрацией.

С Беловского цинкового завода представлены образцы оборотного чернового цинка для оценки возможности центробежной фильтрации от железа. В табл. 19 приведены показатели фильтрации электротермического цинка Беловского завода.

В котле содержание Fе снижается от 0,27 до 0,06\%, но с высоким выходом Zn в дроссы на единицу удаленного железа $\mathrm{Zn} / \mathrm{Fe}=113-157$. Анализ проб брызг из щели фильтра показал, что содержание железа снижается с 0,27\% Fe до 0,03\%. Вмешивание алюминия до соотношения $\mathrm{Al} / \mathrm{Fe}=1,8$ увеличил выход $\mathrm{Zn}$ в дроссы в виде пены. Причем, вмешивание алюминия в цинк при температуре выше $400^{\circ} \mathrm{C}$ ведет к коррозии стального оборудованию. Это отмечается по сумме выхода железа в дроссы и отрафинированный металл, которая в опыте составила 107,4\%.

Особенностью оборотного Беловского цинка в высоком содержании серебра и выход его в дроссы составляет $15 \%$. Высокий выход цинка и серебра в отходы-дроссы не позволяет использовать центрифугу для фильтрации Беловского чернового цинка.

Для ответа на запрос Бельгийской фирмы «Balen-wezel» о возможности центробежной фильтрации железистого цинка провели опыты 
с образцами Бельгийского цинка. Испытания проводили на центрифуге ОП-110 со съемными графитовыми тарелями Д 120 мм. Внутри поверхность чугунного котла и ротор центрифуги покрывали графитовой мастикой. В последствии для укрупненных испытаний поверхность тарелей борировали. В табл. 20 приведены результаты испытаний.

Таблица 19

Результаты центробежной фильтрации цинка от железа

\begin{tabular}{|c|c|c|c|c|c|c|c|c|}
\hline \multirow{2}{*}{ Операция } & \multirow{2}{*}{$\begin{array}{c}\text { Bec, } \\
\text { Кг }\end{array}$} & \multicolumn{4}{|c|}{ Анализ } & \multicolumn{2}{|c|}{$\begin{array}{c}\text { Рост вы- } \\
\text { хода от } \\
\text { исходн }\end{array}$} & \multirow{2}{*}{$\mathrm{Zn} / \mathrm{Fe}$} \\
\hline & & $\begin{array}{c}\mathrm{Fe}, \\
\%\end{array}$ & $\begin{array}{c}\mathrm{Ag} \\
\%\end{array}$ & $\begin{array}{c}\mathrm{Cu}, \\
\%\end{array}$ & $\mathrm{Al}$ & $\begin{array}{c}\mathrm{Fe}, \\
\%\end{array}$ & $\begin{array}{c}\mathrm{Ag} \\
\%\end{array}$ & \\
\hline Исходный цинк & 41,8 & 0,27 & 0,52 & 3,19 & 0 & & & \\
\hline Фильтрация дроссов при $500^{\circ} \mathrm{C}$ & 1,19 & 3,12 & 0,49 & 2,3 & 0 & 32,9 & 2,7 & 29 \\
\hline Фильтрация дроссов при $450^{\circ} \mathrm{C}$ & 3,23 & 1,42 & 0,59 & 2,2 & 0 & 73,5 & 11,5 & 66 \\
\hline Фильтрация дроссов при $450^{\circ} \mathrm{C}$ & 0,85 & 0,83 & 0,50 & 2,2 & 0 & 79,8 & 13,4 & 113 \\
\hline Всего дроссов & 5,27 & 1,71 & 0,55 & 2,3 & 0 & 79,8 & 13,4 & 54 \\
\hline Цинк после фильтрации & 36,5 & 0,06 & 0,52 & 3,3 & 0 & 20,2 & 86,6 & \\
\hline Растворение $\mathrm{Al}$ при $500^{\circ} \mathrm{C}$ & 0,04 & 0,06 & 0,52 & 3,3 & 0,11 & & & \\
\hline Фильтрация дроссов $500^{\circ} \mathrm{C}$ & 0,5 & 0,6 & 0,42 & 2,3 & 0,10 & 82,4 & 14,4 & 157 \\
\hline Фильтрация дроссов $450^{\circ} \mathrm{C}$ & 0,35 & 0,7 & 0,42 & 2,2 & 0,11 & 84,6 & 15,0 & 135 \\
\hline Снято пены & 2,4 & 0,38 & 0,43 & 3,4 & 1,35 & 92,7 & 19,8 & 246 \\
\hline Цинк после фильтрации & 33,3 & 0,05 & 0,52 & 3,34 & 0,02 & 14,7 & 80,2 & \\
\hline
\end{tabular}

Таблица 20

Центробежная фильтрация цинка от железа под карналлитом

\begin{tabular}{|l|c|c|c|c|c|c|c|}
\hline Операция/компонент & $\begin{array}{c}\text { Вес, } \\
\text { кг }\end{array}$ & $\begin{array}{c}\text { Выход, } \\
\%\end{array}$ & $\mathrm{Fe}, \%$ & $\begin{array}{c}\text { Выход Fe, } \\
\%\end{array}$ & $\mathrm{Al}, \%$ & $\mathrm{Al} / \mathrm{Fe}$ & $\mathrm{Zn} / \mathrm{Fe}$ \\
\hline \multicolumn{1}{|c|}{1} & 2 & 3 & 4 & 5 & 6 & 7 & 8 \\
\hline $\mathrm{Zn} \mathrm{Бельгийский}$ & 20 & & 1,8 & & 0 & & \\
\hline Вмешивание $\mathrm{Al}$ & 0,6 & 2,9 & 0,7 & & 98 & & \\
\hline Металл для фильтрации & 20,6 & 100 & 1,77 & 100 & 2,85 & 1,6 & \\
\hline Фильтрация при $690^{\circ} \mathrm{C}$ \\
\hline дроссы & 1,9 & 9,2 & 15,4 & 80,3 & 8,7 & 0,6 & 4,9 \\
\hline цинк & 18,7 & 90,8 & 0,38 & 19,7 & 2,26 & 5,9 & \\
\hline
\end{tabular}


Окончание табл. 20

\begin{tabular}{|l|c|c|c|c|c|c|c|}
\hline \multicolumn{1}{|c|}{1} & 2 & 3 & 4 & 5 & 6 & 7 & 8 \\
\hline Наплавление карналлита \\
\hline Фильтрация $510^{\circ} \mathrm{C}$ \\
\hline дроссы & 0,8 & 4,3 & 6,1 & 68,2 & 4,2 & 0,7 & 14,7 \\
\hline Рафинированный цинк & 17,9 & 95,7 & 0,13 & 31,8 & 2,17 & 17,1 & \\
\hline Общие показатели \\
\hline дроссы & 2,7 & 13,1 & 12,6 & 93,7 & 7,4 & 0,6 & 6,3 \\
\hline Рафинированный цинк & 17,9 & 86,9 & 0,13 & 6,3 & 2,17 & 17,1 & \\
\hline
\end{tabular}

Растворение тарелей и котла не наблюдалось, но цинк получен с содержанием $0,13 \% \mathrm{Fe}$, в то время как для марки Ц3 требуется менее $0,1 \%$. Для получения цинка марки Ц0 требуется отделять железо до содержании менее $0,005 \%$. Однако, электролитическая очистка железистого цинка значительно осложняется высоким выходом шламов.

Поэтому, железистый цинк с высоким (более 0,4\%) содержанием железа может перерабатываться центробежной фильтрацией.

Стальные металлоконструкции крепежные детали, листы, трубопроводы для придания сопротивления коррозии подвергаются цинкованию, т.е. нанесению слоя цинка на поверхности стали. Одним из способов цинкования стальных труб, листа, конструкций является горячее цинкование. В ванне наплавляют цинк марок Ц-1, Ц-3. Стальную полосу непрерывно тянут через слой расплавленного цинка толщиной 500 мм при температуре $460-470^{\circ} \mathrm{C}$. Полоса покрывается цинком толщиной 14-90 мкм [29]. При этом в ванне цинка накапливается растворяющееся железо. Растворенное железо создает условия образования брака цинкового покрытия [2]. Поэтому во избежание образования брака цинкового покрытия еженедельно вычерпывают железистый гартцинк со дна ванны. Отходы ванн горячего цинкования представляют собой гартцинк, содержащий 91-95\% цинка, 2-4,3\% железа [31].

\section{1. Кинетика удаления железа из гартцинка}

Опыты по рафинированию гартцинка от железа проводили центробежной фильтрацией на погружаемой центрифуге модели ЦП-200 (рис. 37). Аппарат представляет собой ротор 1 с фильтром 2 из двух конусообразных тарелей 3 сжатых большими основаниями с образованием фильтрующей щели 4. Основание конуса у ротора снабжено заборными окнами 5. В верхней части ротор 1 снабжен пружиной 6 для сжатия 


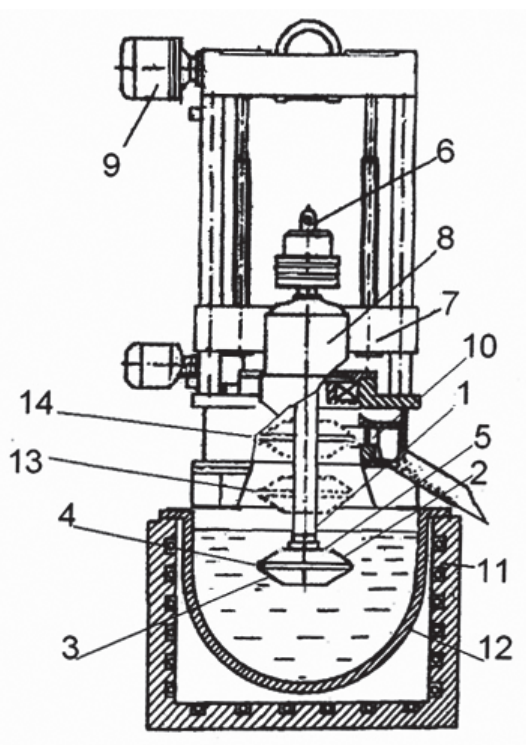

Pис. 37. Центрифуга модели ЦП-200. Основные узлы: 1 - ротор; 2 - фильтр тарельчатый; 4- фильтрующая щель; 5-заборные окна; 6-пружина; 8- привод вращения; 9 - привод подвема ротора; 10 - скребковый транспортер;

13-положение фильтра при отжиме; 14 - положение фильтра при выбросе дроссов

тарелей и укреплен на траверсе 7, соединенной с приводами вращения 8 и подъема ротора 9. Размер фильтрующей щели 4 регулируется сжатием пружины 6 и обычно составляет 0,1 мм. С помощью привода 9 ротор 1 с фильтром 2 погружается в расплав и приводится во вращение.

Во время вращения фильтра в расплаве через заборные окна 5 расплав всасывается во внутреннюю полость тарелей, образованную торцами оснований тарелей и под действием центробежных сил жидкая фаза (очищенный металл) продавливается через фильтрующую щель 4 и выбрасывается в общий расплав в котле, а твердые кристаллы примесей в виде дроссов остаются в полости фильтра у кромки фильтрующей щели 4. Фильтр диаметром 200 мм с емкостью полости 0,56 л изображен на рис. 38 с наполненными дроссами. По истечении заданного времени вращающийся ротор с фильтром не прекращая вращения поднимался над поверхностью рафинируемого металла выбрасывая жидкую фазу через фильтрующую щель.

При подъеме до фиксированного уровня «уровень отжима» 13 (рис. 37) процессор переключает привод на увеличение числа оборотов на задаваемое время для удаления остатков расплавленной фазы из осадка в полости фильтра и происходит до удаление остатков жидкого металла оставшегося между кристаллами дроссов т.е. происходит «досушка» осадка от жидкой фазы. Брызги жидкого расплава стекают по конусу отбойника в котел. После осушки осадка через 15-30 с, задаваемое процессором время, вращающийся фильтр поднимается до зоны выброса дроссов «уровня 14 скребкового транспортера 10» на рис. 37, где с помощью сжатия пружины 6 тарели раскрываются и осадок под действием центробежных сил выбрасывается из полости раскрывшихся тарелей фильтра 
на движущийся скребковый транспортер 10, который выгружает их в тару. Количество погружений фильтра на заполнение осадком фиксировалось по счетчику [6].

Скорость вращения ротора центрифуги изменялась подачей напряжения на двигатель постоянного тока и измерялась тахометром ТЧ-10Р и периодически контролировалась строботахометром TC 32. Длительность вращения фильтра в расплаве и над расплавом регулировалась установкой датчика реле УТ23-PIC. Котел снабжен

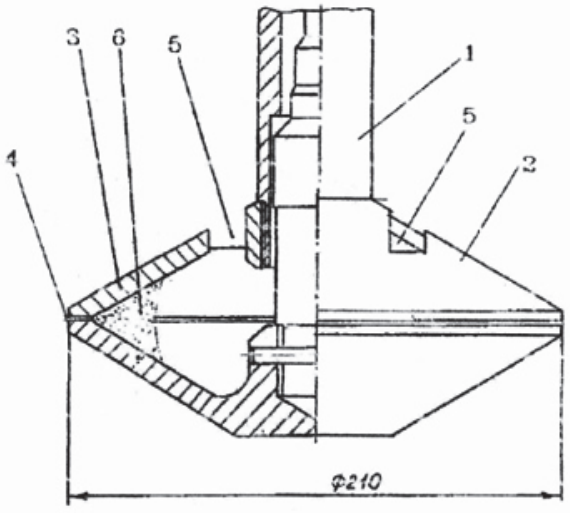

Рис. 38. Фильтр от ЦП-200.

Основные узлы: 1 - ротор; 2 - фильтр в целом; 3 - верхняя тарель; 4- фильтрующая щель; 5 - заборные окна; 6 - собранные дроссы электрообогревом с регулятором температуры ТРМ201 с TXА термопарой. Центрифуга устанавливалась на чугунный котел емкостью 80 л, диаметром 500 мм, глубиной 400 мм. В котел загружались по весу слитки гартцинка, расплавлялись, расплав перемешивался пропеллерной мешалкой и устанавливалась заданная температура и проводилось отделение твердых дроссов из расплава фильтрации.

Разгруженный дросс взвешивался и после проборазделки на прибоpe Fritsch - проба анализировалась атомно адсобционным методом на атомно-эмиссионном спектрометре с индуктивно связанной плазмой IRIS Intrepid компании INTERTECH Corporation.

В первую очередь исследовали процесс степени удаления железа. В табл. 21. показана кинетика удаления железа и выход цинка в дроссы [6].

Кинетика очистки гартцинка от железа при температуре $400{ }^{\circ} \mathrm{C}$ на рис. 39 показала, что с увеличением длительности фильтрации выход\% $\mathrm{Fe}$ в дроссы повышается в степенной зависимости по уравнению:

$$
(\mathrm{Bdx} \% \mathrm{Fe})_{\text {др }}=11,65 \cdot(\text { мин })^{0,54} \text { с корреляцией 0,99, }
$$

где $(\mathrm{Bdx} \% \mathrm{Fe})_{\text {др }}$ - выход железа в дроссы в \%; (мин) - длительность фильтрации в мин. 
Таблица 21

Кинетика удаления железа из гартцинка центробежной фильтрацией

\begin{tabular}{|c|c|c|c|c|c|c|c|}
\hline \multirow{3}{*}{$B_{\text {fil }}$, мин } & \multirow{3}{*}{$\begin{array}{c}\text { Вес } \\
\text { дроссов, } \\
\text { Кг }\end{array}$} & \multicolumn{4}{|c|}{ Анализы } & \multirow{3}{*}{$S_{\mathrm{Fe},} \%$} & \multirow{3}{*}{$\begin{array}{l}\mathrm{Zn} / \mathrm{Fe} \\
\text { дроссы }\end{array}$} \\
\hline & & \multicolumn{2}{|c|}{ дроссов } & \multicolumn{2}{|c|}{ расплава } & & \\
\hline & & $\mathrm{Fe}, \%$ & $\mathrm{Al}, \%$ & $\mathrm{Fe}, \%$ & $\mathrm{Al}, \%$ & & \\
\hline 1 & 1,25 & 3,99 & 1,90 & 0,60 & 0,60 & 10,1 & 23,6 \\
\hline 2 & 1,12 & 3,63 & 1,94 & 0,55 & 0,58 & 18,4 & 26,0 \\
\hline 4 & 0,99 & 3,83 & 1,95 & 0,50 & 0,56 & 26,2 & 24,6 \\
\hline 6 & 0,86 & 3,36 & 1,99 & 0,46 & 0,54 & 32,0 & 28,1 \\
\hline 8 & 0,73 & 3,33 & 2,03 & 0,43 & 0,53 & 37,0 & 28,4 \\
\hline 10 & 0,6 & 3,54 & 2,04 & 0,40 & 0,51 & 41,3 & 26,7 \\
\hline 11 & 0,45 & 3,18 & 2,05 & 0,38 & 0,50 & 44,2 & 29,8 \\
\hline 13 & 0,46 & 3,25 & 2,10 & 0,36 & 0,49 & 47,3 & 29,1 \\
\hline 15 & 0,58 & 3,46 & 2,12 & 0,34 & 0,48 & 51,4 & 27,3 \\
\hline 17 & 0,51 & 3,00 & 2,16 & 0,32 & 0,47 & 54,5 & 31,7 \\
\hline 19 & 0,49 & 3,00 & 2,16 & 0,30 & 0,46 & 57,5 & 31,7 \\
\hline 22 & 0,43 & 2,57 & 2,26 & 0,28 & 0,45 & 59,7 & 37,0 \\
\hline 23 & 0,25 & 2,82 & 2,25 & 0,27 & 0,44 & 61,1 & 33,6 \\
\hline 24 & 0,1 & 2,40 & 2,25 & 0,26 & 0,43 & 61,6 & 39,7 \\
\hline
\end{tabular}

Обозначения: $B_{f l}-$ длительность фильтации, мин; $S_{\mathrm{Fe}}-$ степень \% удаления железа.

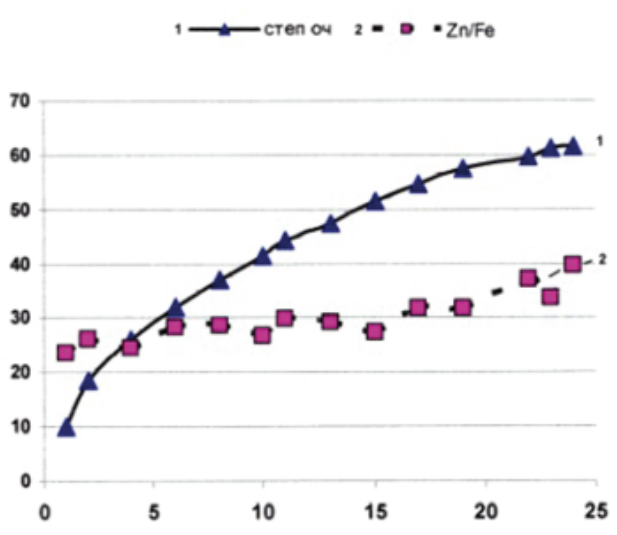

Рис. 39. Кинетика удаления железа из гартиинка. Абсцисса - длительность очистки, мин; ардината: 1 - выход \% Fе в дроссы;

2 - доля $(\mathrm{Zn} / \mathrm{Fe})$ выхода цинка в дроссы на единииу удаленного железа
Доля выхода цинка $(\mathrm{Zn} / \mathrm{Fe})_{d r} \quad$ (это показатель, характеризующий выход цинка на единицу удаленного железа) по мере увеличения длительности фильтрации медленно повышаются по уравнению:

$$
(\mathrm{Zn} / \mathrm{Fe})_{\text {др }}=0,53 \cdot(\text { мин })+
$$
$+23,2$ с корреляцией $0,81,(5.2)$

где $(\mathrm{Zn} / \mathrm{Fe})_{\text {др }}$ - выход цинка в дроссы на еденицу удаленного железа; (мин) длительность фильтрации в мин [6]. 


\section{2. Вдияние температуры расплава при фильтрации}

Согласно диаграммы состояния системы цинк-железо растворимость железа в цинке возрастает и существенно влияет на показатели фильтрации.

Опыты приведенные в табл. 22.5 показали, что с увеличением температуры фильтрации в интервале $400-500^{\circ} \mathrm{C}$ степень удаления железа снижается [31].

Таблица 22

Влияние температуры фильтрации на конечное содержание Fe в металле

\begin{tabular}{|l|c|c|c|c|c|c|c|}
\hline \multicolumn{1}{|c|}{ Номер опыта } & 1 & 2 & 3 & 4 & 5 & 6 & 7 \\
\hline Температура расплава, ${ }^{\circ} \mathrm{C}$ & 420 & 430 & 440 & 450 & 450 & 475 & 490 \\
\hline Растворимость Fe в Zn, \% & 0,02 & 0,02 & 0,04 & 0,06 & 0,06 & 0,12 & 0,15 \\
\hline Дин вязкость Zn, мПа·с & 33,4 & 33,4 & 32,6 & 31,7 & 31,7 & 29,5 & 28,1 \\
\hline [Fe], \% в исходном металле & 0,23 & 0,37 & 0,38 & 0,32 & 0,36 & 2,6 & 0,23 \\
\hline [Fe], \%конечный металл & 0,14 & 0,12 & 0,09 & 0,11 & 0,10 & 1,04 & 0,03 \\
\hline Выход дроссов, \% & 2,1 & 4,3 & 8,6 & 6,3 & 6,9 & 30,3 & 12,8 \\
\hline [Fe], \% в дроссах & 4,32 & 5,92 & 3,4 & 3,47 & 3,79 & 6,2 & 1,6 \\
\hline Выход, \% Fе в дроссы & 38,7 & 69,3 & 74,3 & 68,7 & 72,9 & 72,3 & 88,8 \\
\hline Доля выхода (Zn/Fе) в дроссы & 22,1 & 15,9 & 28,4 & 27,8 & 25,4 & 15,1 & 61,5 \\
\hline
\end{tabular}

Примечание: загрузка 50 кг цинка.

Конечное содержание железа в металле достигается предпочтительному содержанию при температуре $440-450^{\circ} \mathrm{C}$.

Выход железа в дроссы не стабильно повышается при температуре $430-470^{\circ} \mathrm{C}$.

Зависимость на рис. 40 показывает, что в интервале $430-480^{\circ} \mathrm{C}$ температур наблюдается стабилизация потерь цинка в дроссы, но затем с повышением температуры отмечается резкое повышение доли выхода цинка в дроссы [31].

В целом выход, \% Fе в дроссы повышается по уравнению:

$$
(\mathrm{Bыx} \% \mathrm{Fe})_{\mathrm{dr}}=0,43 \cdot T_{\phi}-125,8 \text { с кореляцией } 0,72 \text {, }
$$

где $T_{\phi}-$ температура фильтрации в ${ }^{\circ} \mathrm{C}$.

Для более полного удаления железа из расплавленного цинка необходима температура $440^{\circ} \mathrm{C}$ фильтрации в условиях минимальной растворимости железа в цинке. При температуре $440^{\circ} \mathrm{C}$ растворимость $\mathrm{Fe}$ 
в цинке минимальна, но и вязкость расплава Zn выше чем при $480^{\circ} \mathrm{C}$. Однако, с повышением температуры повышается растворение мелких кристаллов и снижается вязкость суспензии расплава. Поэтому по всей вероятности снижается выход жидкого цинка с осадком дроссов. При $T>500^{\circ} \mathrm{C}$ растворимость Fe повышается. Это показывает анализ кольца брызг из щели фильтра, которое содержит 0,32\% Fe). В интервале температур $430-480^{\circ} \mathrm{C}$ содержание Fе после фильтрации не меняется, а с повышением $T_{\phi}>500^{\circ} \mathrm{C}$ резко повышается:

$$
100 \cdot[\mathrm{Fe}]_{k}=0,32 \cdot T_{\phi}-128 \text { с кореляцией } 0,84 .
$$

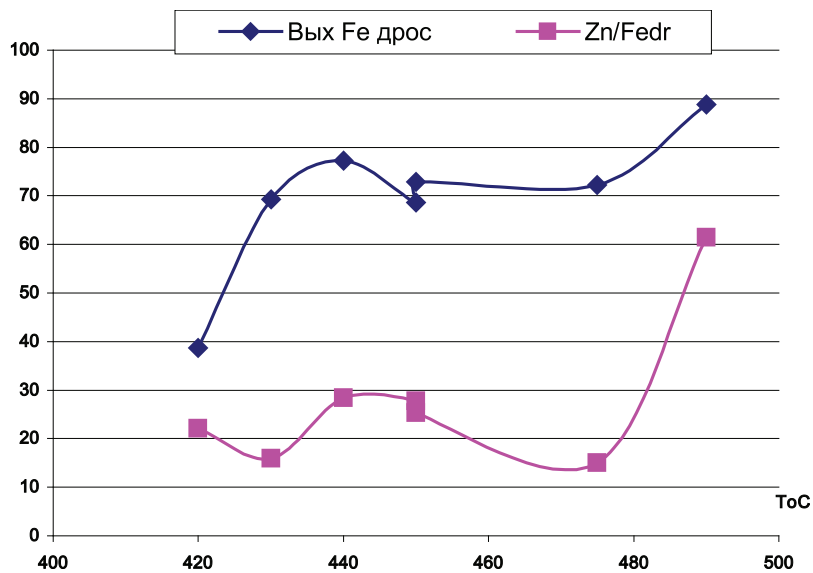

Рис. 40. Влияние температуры фильтрации расплавленного гартцинка. Абсцисса - температура фильтрации; ордината: 1 - выход, \% Fе в дроссы;

2 - доля $(\mathrm{Zn} / \mathrm{Fe})$ выхода цинка в дроссы на единииу удаленного железа

Поэтому можно принять температуру фильтрации $430-480{ }^{\circ} \mathrm{C}$ оптимальной.

Для снижения выхода цинка в отходы необходимо отделять жидкий цинк с поверхности твердых кристаллов соединений дроссов. Для этого проведен расчет доли твердой фазы в расплаве и оценка крупности кристаллов в осадке и толщины пленки на кристаллах.

Исходный гартцинк из ванн цинкования кристаллизовался в течение месяца и равновесный состав принят в виде твердых соединений $\mathrm{FeZn}_{7}$. Однако, при повторной переплавке гартцинка для переработки происходит неравновесная перекристаллизация и согласно диаграммы железо находится в виде фаз переменного состава. 
В диаграмме состояния [17] сплава $\mathrm{Zn}-\mathrm{Fe}$ известна фаза $\delta_{1}$ состава $\mathrm{FeZn}_{7}$ и фаза $\xi$ состава $\mathrm{FeZn}{ }_{10}$ стабильные при температуре ниже $530^{\circ} \mathrm{C}$. При охлаждении расплава до $530^{\circ} \mathrm{C}$ с содержанием $[\mathrm{Fe}]=1,3-3,45 \%$ в жидком $\mathrm{Zn}$ выделяется твердый сплав $\delta$, содержаший 8,6-11,5 ат\% $\mathrm{Fe}$,

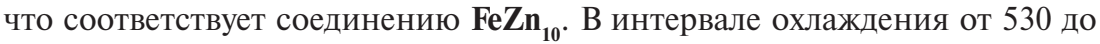
$420^{\circ} \mathrm{C}$ но уже при содержании $\mathrm{Fe}<0,3 \%$ в жидком $\mathrm{Zn}$ выделяется твердая фаза $\xi$ состава 7,05\% Fe, что соответствует соединению FeZn $\mathbf{1 3}_{13}$. Таким образов в этих условиях основной твердой фазой является $\mathbf{F e Z n _ { 1 0 }}$.

Образец пористых кристаллов дроссов из фильтра содержащих $3,12 \%$ железа, 95,9\% цинка исследован на удельную поверхность методом адсорбции аргона [5]. Удельная поверхность дроссов составила 0,515 м²/г. Для расчета (табл. 23) фазового состава примем, что цинк одинаково смачивает кристаллы соединений.

Таблица 23

Расчет фазового состава фильтр-осадка

\begin{tabular}{|c|c|c|}
\hline Статья расчета & $\begin{array}{c}\text { Единицы } \\
\text { измерения }\end{array}$ & Значение \\
\hline Содержание железа в осадке, $\%$ & $\%$ & 3,12 \\
\hline цинка, \% & $\%$ & 90,7 \\
\hline Удельная поверхность $S$ & $S=\mathrm{M}^{2} / \Gamma$ & 0,515 \\
\hline Удельная поверхность $S$ & $\mathrm{CM}^{2} / \Gamma$ & 5150 \\
\hline 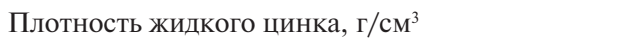 & $\Gamma / \mathrm{cm}^{3}$ & 6,02 \\
\hline Плотность твердой фазы & $\gamma, \Gamma / \mathrm{cm}^{3}$ & 7,19 \\
\hline Расчет доли твердой фазы & $\%$ & 39,7 \\
\hline Доля цинка связанного в $\mathrm{FeZn} \mathrm{n}_{10}$ & $\%$ & 36,6 \\
\hline Содержание железа в кристалле $\mathrm{FeZn} \mathrm{n}_{10}$ & & 7,9 \\
\hline Содержание цинка в кристалле $\mathrm{FeZn} \mathrm{Z}_{10}$ & & 92,1 \\
\hline Доля свободного цинка в дроссах, \% & $\%$ & 54,1 \\
\hline Объем жидкого цинка в 1 г осадка & $\mathrm{CM}^{3}$ & 0,08992 \\
\hline Толщина пленки цинка на частицах твердой фазе & $\mathrm{cm}$ & $1,7 \mathrm{E}-05$ \\
\hline 1 см $=10000$ микрон $(\mu)$ & $\mu$ & 10000 \\
\hline Толщина пленки цинка на частицах твердой фазе & $\mu$ & $\mathbf{0 , 1 7}$ \\
\hline Удельный объем 1 г твердой фазы $\mathrm{FeZn} \mathrm{Zn}_{10}$ & $\mathrm{cM}^{3} / \Gamma$ & 0,05521 \\
\hline Средний размер кристаллов $\mathrm{FeZn} \mathrm{n}_{10}$ & $\mathrm{~cm}$ & 0,00008 \\
\hline Сред размер кристал $\mathrm{FeZn}_{10}$ & микрон & 0,8 \\
\hline
\end{tabular}


Расчет показал, что при среднем размере частиц твердой фазы FeZn $\mathrm{n}_{10}$ в 0,8 микрон толщина пленки жидкого олова 0,17 микрон.

Поэтому полагаем, что снижения выхода цинка в дроссы можно достигнуть за счет снижения удельной поверхности кристаллов дроссов, т.е. крупности кристаллов. Высокий выход цинка в отфильтрованные дроссы (показатель $\mathrm{Zn} / \mathrm{Fe}$ ) объясняется образованием кристаллов $\mathrm{FeZn}_{7}$ различной крупности покрытых пленкой жидкого цинка за счет высокой смачиваемости.

Для снижения выхода цинка в дроссы необходимо укрупнение кристаллов кристаллизацией и снижения удельной поверхности частиц сыпучих дроссов. Степень удаления железа центробежной фильтрацией зависит от условий кристаллизации этих соединений из расплава, т.е. условий роста кристаллов этих соединений железа.

\section{3. Укрупнение частиц кристалдизацией}

Для повышения крупности кристаллов металл нагревался до заданной температуры и охлаждался до температуры фильтрации. Результаты приведены в табл. 24.

Таблица 24

Влияние температуры кристаллизации расплава гартцинка

\begin{tabular}{|c|l|l|l|l|l|l|l|l|c|c|}
\hline $\begin{array}{c}\text { № } \\
\text { п/п }\end{array}$ & & 11 & 12 & 13 & 14 & 16 & 17 & 18 & 19 & 20 \\
\hline 1 & Т начала перекристаллизации ${ }^{\circ} \mathrm{C}$ & 450 & 450 & 500 & 530 & 540 & 540 & 600 & 600 & 600 \\
\hline 2 & Т интервал кристаллизации ${ }^{\circ} \mathrm{C}$ & 20 & 50 & 50 & 70 & 100 & 110 & 155 & 160 & 170 \\
\hline 3 & Fе \% в исходном металле & 0,32 & 0,23 & 0,23 & 0,41 & 0,38 & 0,37 & 0,32 & 0,2 & 0,38 \\
\hline 4 & Выход дроссов, \% & 5,67 & 2,06 & 2,88 & 1,00 & 8,64 & 4,33 & 5,45 & 8,85 & 5,46 \\
\hline 5 & Содержание Fе \% в дроссах & 2,4 & 4,3 & 3,1 & 3,1 & 3,4 & 5,9 & 4,7 & 1,8 & 6,0 \\
\hline 6 & Выход \% Fе в дроссы & 42,0 & 47,4 & 49,1 & 57,6 & 67,3 & 69,3 & 79,4 & 78,0 & 75,8 \\
\hline 7 & Доля выхода в дроссы (Zn/Fе) & 38,4 & 32,1 & 31,1 & 30,9 & 28,4 & 25,9 & 20,5 & 24,3 & 15,7 \\
\hline 8 & Fе \% в отрафинированном металле & 0,20 & 0,14 & 0,14 & 0,12 & 0,09 & 0,12 & 0,07 & 0,04 & 0,06 \\
\hline
\end{tabular}

Примечание: исходная загрузка - 60 кг цинка.

Для снижения выхода цинка в дроссы необходимо укрупнение кристаллов кристаллизацией и снижения удельной поверхности частиц сыпучих дроссов. Степень удаления железа центробежной фильтрацией зависит от условий кристаллизации этих соединений из расплава, т.е. условий роста кристаллов этих соединений железа. 
Для повышения крупности кристаллов металл нагревался до заданной температуры и охлаждался до температуры фильтрации.

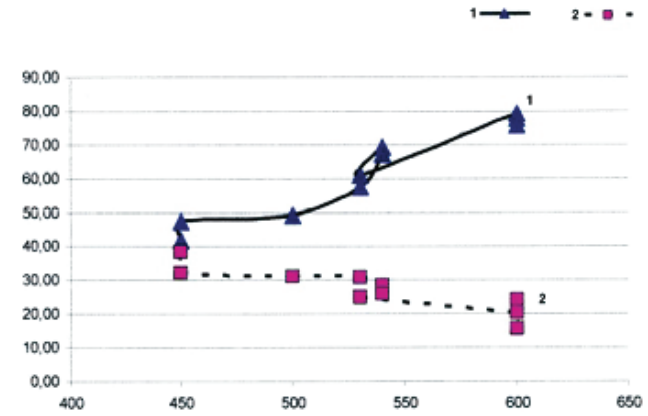

Рис. 41. Влияние начальной температуры кристаллизации.

Абсцисса - температура фильтрации, ${ }^{\circ}$; ; ордината: 1 - выход процента железа в дроссы; 2 - доля $(\mathrm{Zn} / \mathrm{Fe})$ выхода цинка в дроссы на единииу удаленного железа

На графике наблюдается перегиб при $540^{\circ} \mathrm{C}$. С увеличением начальной температуры кристаллизации доля выхода цинка в дроссы снижаются.

С увеличением начальной температуры кристаллизации выход железа в дроссы увеличивается (рис. 41) по уравнению:

$$
(\text { Вых } \% \mathrm{Fe})_{\text {др }}=0,23 \cdot T_{\text {исх }}-62,6 \text { с корреляцией } 0,94 \text {, }
$$

где $T_{\text {исх }}$ - начальная температура кристаллизации охлаждением.

Отмечено, что на показатели фильтрации влияет не только величина начальной температуры кристаллизации, но интервал температур при которых проходит кристаллизация (рис. 42).

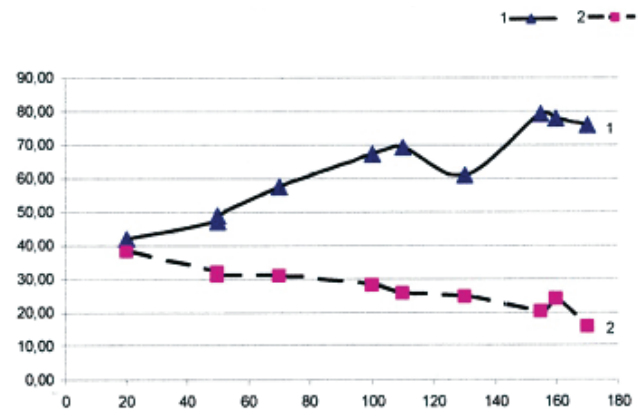

Рис. 42. Влияние интервала кристаллизации на показатели фильтрации. Абсцисса - интервал температуры кристаллизации, ${ }^{\circ} \mathrm{C}$; ордината: 1 - выход процента железа в дроссы; 2 -доля $(\mathrm{Zn} / \mathrm{Fe})$ выхода цинка в дроссы на единииу удаленного железа 
С увеличением интервала кристаллизации $\Delta T,{ }^{\circ} \mathrm{C}$ возрастает выход $\mathrm{Fe}$ с дроссами по уравнению [31]:

$$
(\text { Вых } \% \mathrm{Fe})_{\text {др }}=0,25 \cdot(\Delta T)+37,6 \text { с корреляцией 0,91. }
$$

С увеличением интервала кристаллизации выход цинка в дроссы снижается по уравнению:

$$
(\mathrm{Zn} / \mathrm{Fe})_{\text {др }}=38,2-0,10 \cdot(\Delta T) \text { с корреляцией } 0,80 .
$$

\section{4. Вдияние содержания алюминия}

Существенное снижение выхода цинка в дроссы достигается связыванием железа в тугоплавкого соединения железа с алюминием $\mathrm{FeAl}_{2}$. Известен способ снижения выхода цинка в дроссы [32] при рафинирования гартцинка от железа вмешиванием алюминия при температуре $600-500^{\circ} \mathrm{C}$ и центробежной фильтрацией, а затем после охлаждения до температуры $420-450^{\circ} \mathrm{C}$ снова проводят центробежную фильтрацию. Для выявления условий снижения выхода цинка в дроссы проведены опыты (табл. 25) по определению оптимального содержания алюминия в расплаве.

Таблица 25

\begin{tabular}{|c|c|c|c|c|c|c|c|c|}
\hline Номер опыта & 21 & 22 & 23 & 24 & 25 & 26 & 27 & 28 \\
\hline Исходный металл, \% Fe & 2,62 & 1 & 2,98 & 2,7 & 0,6 & 1,35 & 1,28 & 0,52 \\
\hline Процент Al в метале & 0,42 & 0,4 & 1,94 & 2,1 & 0,49 & 1,11 & 1,38 & 0,61 \\
\hline$(\mathrm{Al} / \mathrm{Fe})_{\text {ат }}$ в металле & 0,33 & 0,83 & 1,35 & 1,6 & 1,69 & 1,70 & 2,23 & 2,44 \\
\hline Конечный процент Fe & 2,35 & 0,7 & 1,92 & 0,2 & 0,26 & 0,75 & 1,60 & 0,30 \\
\hline Процент Fe в дроссах & 9,99 & 5,3 & 6,47 & 6,3 & 5,10 & 6,17 & 6,41 & 5,43 \\
\hline Процент Al в дросссах & 10,17 & 2,0 & 4,84 & 5,3 & 2,09 & 2,53 & 5,61 & 0,61 \\
\hline$(\mathrm{Al} / \mathrm{Fe})_{\text {ат }}$ в дроссах & 2,11 & 0,78 & 1,55 & 1,7 & 0,85 & 0,85 & 1,81 & 0,23 \\
\hline Выход \% Fе в дросссы & 13,6 & 38 & 50,6 & 53,2 & 53,1 & 50,3 & 42,5 & 45,1 \\
\hline$(\mathrm{Zn} / \mathrm{Fe})$ в дроссах & 8,0 & 17,5 & 13,7 & 14,1 & 16,2 & 14,15 & 14,4 & 17,3 \\
\hline
\end{tabular}

Влияние соотношения $(\mathrm{Al} / \mathrm{Fe})_{\text {ат }}$ на показатели фильтрации

Примечание: температура фильтрации $480^{\circ} \mathrm{C}$.

Результаты опытов на рис. 43 показывают, что доля выхода цинка с дроссами на единицу удаленного железа пропорционально зависит от содержания алюминия и уменьшаются при соотношении $(\mathrm{Al} / \mathrm{Fe})_{\text {at }}$ более $0,8[4]$. 


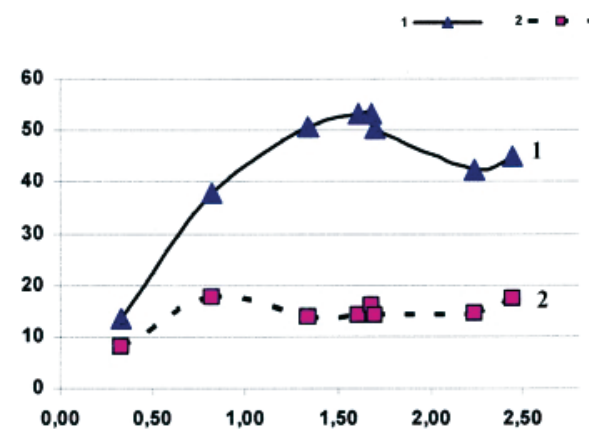

Рис. 43. Влияние $(\mathrm{Al} / \mathrm{Fe})_{\text {ат }}$ на показатели фильтрации.

Aбсиисса - соотношение Al/Fe в расплаве; ордината: 1 - выход \% Fe в дроссы;

2 - доля $(\mathrm{Zn} / \mathrm{Fe})$ выхода цинка в дроссы на единииу удаленного железа

Графическая обработка опытов (рис. 43) показывает, что до соотношения $(\mathrm{Al} / \mathrm{Fe})_{\text {at }}<1,6$ выход железа в дроссы возрастает по уравнению:

$$
\text { Вых } \mathrm{Fe}_{\text {др }}=17,2 \cdot(\mathrm{Al} / \mathrm{Fe})_{\text {at }}-3,5 \text { с корреляцией 0,9. }
$$

При соотношении $(\mathrm{Al} / \mathrm{Fe})_{\text {at }}>1,6$ выход железа в дроссы начинает снижаться.

Доля выхода цинка с дроссами (выход цинка в дроссы) на единицу удаленного железа пропорционально зависит от содержания алюминия и при соотношении $(\mathrm{Al} / \mathrm{Fe})_{\text {at }}$ более 0,8 уменьшаются. Оптимальным можно признать соотношение $(\mathrm{Al} / \mathrm{Fe})_{\text {at }}=1,3-1,6$.

При повышении концентрации алюминия соотношении $(\mathrm{Al} / \mathrm{Fe})_{\text {at }}$ более 1,6 выход железа в дроссы снижается. Это можно объяснить образованием алюминиевой пены соединений железа и ее окислением. Пена мелкодисперсных соединений железа с алюминием проскакивает через фильтр, концентрируется на поверхности расплавленного цинка и частично окисляется. Так как на поверхности расплава

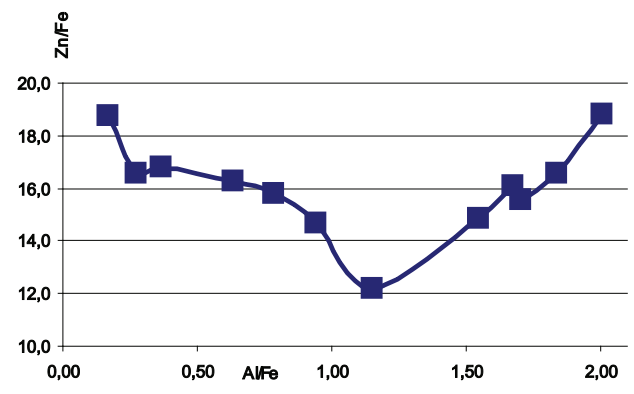

Рис. 44. Влияние соотношения $(\mathbf{A l} / \mathbf{F e})_{\text {am }}$ на выход иинка в дроссы. Абсцисса - соотношение $(\mathrm{Al} / \mathrm{Fe})_{\text {ат }}$ в исходном металле; ордината - 1-выход цинка $(\mathrm{Zn} / \mathrm{Fe})$.в дроссы 
выделяется четкий слой, более вязкой массы, которая частично проскакивает через зазор 0,1 мм щели фильтра, то в технической документации этот слой обозначили пеной [5].

При соотношении алюминия к железу $(\mathrm{Al} / \mathrm{Fe})_{\text {is }}>1$ в расплаве гартцинка соединения железа в расплаве реагируют с алюминием протекают предпочтительно по реакции (5.6) первого порядка.

В увеличенном масштабе представлен рис. 44, где показано, что при соотношении $(\mathrm{Al} / \mathrm{Fe})_{\mathrm{at}}=0,9-1,6$ выход цинка в дроссы $(\mathrm{Zn} / \mathrm{Fe})$ стремится к минимуму с дальнейшим повышением за счет образования пены.

\section{5. Образование пены при центробежной фильтрации}

Существенное снижение выхода цинка в дроссы достигается оптимизацией концентрации алюминия в расплаве. При соотношении $(\mathrm{Al} / \mathrm{Fe})_{\text {at }}>1,6$ выход железа в дроссы начинает снижаться. Это можно объяснить образованием алюминиевой пены соединений железа. Пена мелкодисперсных соединений железа с алюминием проскакивает через фильтр, концентрируется на поверхности расплавленного цинка.

Так как на поверхности расплава в отличие от сыпучих дроссов разделяется четкий жидкий слой, который частично проскакивает через зазор 0,1 мм щели фильтра, то этот слой обозначили «пеной». При продолжительном перемешивании расплава слой пены становится пористым, а при дальнейшим перемешивании превращается в сыпучие дроссы. Выход таких дроссов значительно превышает выход пены с высоким выходом цинка в такие дроссы [4].

Поэтому можно предположить, что образующаяся пена не является насыщением металла воздухом как в обычных пенах. При перемешивании расплава мелкодисперсные кристаллы $\mathrm{FeAl}_{2}$ окисляются с поверхности, а окисленные кристаллы плохо смачиваются цинком и всплывают на поверхность расплава в виде пены [5].

Мелкодисперсные кристаллы $\mathrm{FeAl}_{2}$ окисленные с поверхности не кристаллизуются в более крупные кристаллы. В присутствии пены кристаллы соединений железа в значительной доле проскакивает фильтр и требуется длительное время для заполнения щели и фильтра. По мере увеличения длительности фильтрации наполнение фильтра значительно снижается хотя визуально видно, что на поверхности еще имеются дроссы в виде пены.

Испытан вариант фильтрации пены путем периодического добавления зернистого материала, чтобы увеличить наполнение фильтра дроссами [4]. В отдельном опыте на металле содержащем $1,78 \% \mathrm{Fe}$ и алюминий c соотношением $(\mathrm{Al} / \mathrm{Fe})_{\text {at }}=2,24$ при температуре $480^{\circ} \mathrm{C}$ периодически 66 
добавлялся гранулированный шлак крупностью 1-3 мм с расходом $3 \%$ от объема фильтра. После подобных добавок относительная производительность набора фильтра увеличивается на 9-88\% и относительная степень удаления Fe возрастает на 5-25\%, но увеличивается относительный выход цинка $\mathrm{Zn} / \mathrm{Fe}$ в дроссы на 20-60\%. Показатели «относительный» означает величину скачка в сравнении с предыдущим моментом. В конечном итоге полный выход дроссов составил 28,1\% с выходом цинка в дроссы $(\mathrm{Zn} / \mathrm{Fe})=14,8$, т.е. выход цинка в дроссы на единицу удаленного железа. В опыте с меньшим содержанием железа $(0,96 \%)$ и меньшим расходом алюминия $1,87(\mathrm{Al} / \mathrm{Fe})$ at при такой же температуре фильтрации $480^{\circ} \mathrm{C}$ в моменты после добавки гранулированного шлака относительная производительность набора фильтра увеличивается только на 12-20\%. Относительная степень удаления Fe возрастает на 8-80\%, но увеличивается относительный выход цинка $(\mathrm{Zn} / \mathrm{Fe})$ в дроссы на 7-53\%. В целом полный выход дроссов снижается до $21,7 \%$, но увеличился выход цинка ( $\mathrm{Zn} / \mathrm{Fe})$ в дроссы до значения 21,6 [4, 5].

В табл. 26 приведены опыты с характерным образованием пены на поверхности ванны расплава. Кроме того отбирались пробы брызг металла из фильтра в процессе осушки дроссов в положении вращающегося фильтра, поднятом над расплавом.

Таблица 26

Состав пены и брызг металла при центробежной фильтрации гартцинка

\begin{tabular}{|l|c|c|c|c|c|c|c|c|}
\hline Номера плавок & 29 & 30 & 31 & 32 & 33 & 34 & 35 & 36 \\
\hline Гартцинк (Al/Fe) at & 1,60 & 1,66 & 2,07 & 2,13 & 2,16 & 2,23 & 2,23 & 2,7 \\
\hline$T,{ }^{\circ} \mathrm{C}$ фильтрации & 495 & 480 & 480 & 495 & 485 & 470 & 490 & 460 \\
\hline Содержание, \% Fe & 1,65 & 0,96 & 9,70 & 3,46 & 0,53 & 1,78 & 1,78 & 2,9 \\
\hline Брызги из фильтра, \% Fe & 0,50 & 0,38 & 0,32 & 0,24 & 0,14 & 0,03 & 0,13 & 0,1 \\
\hline Процент $\mathrm{Al}$ & 0,45 & 0,38 & 0,18 & 0,39 & 0,04 & 0,28 & 0,21 & 1,5 \\
\hline$\left(_{\mathrm{Al} / \mathrm{Fe})_{\text {at }}}\right.$ & 1,86 & 2,07 & 1,16 & 3,36 & 0,59 & 4,82 & 3,34 & 27,6 \\
\hline Пена на металле, \% Fe & 0,42 & 0,44 & 3,70 & 3,80 & 1,15 & 1,95 & 2,00 & 4,0 \\
\hline Пена \% $\mathrm{Al}$ & 0,21 & 0,07 & 14,62 & 3,98 & 0,88 & 1,94 & 1,63 & 1,5 \\
\hline Пена (Al/Fe) at & 1,03 & 0,33 & 8,17 & 2,16 & 1,58 & 2,06 & 1,68 & 0,8 \\
\hline Дроссы \% $\mathrm{Fe}$ & 10,08 & 4,73 & 9,99 & 8,55 & 5,37 & 6,22 & 6,48 & 7,5 \\
\hline Процент $\mathrm{Al}$ & 8,55 & 2,90 & 10,12 & 9,63 & 4,24 & 5,90 & 4,80 & 6,1 \\
\hline$(\mathrm{Al} / \mathrm{Fe})_{\text {at }}$ & 1,75 & 1,27 & 2,09 & 2,33 & 1,63 & 1,96 & 1,53 & 1,7 \\
\hline Выход (Zn/Fe) $d r$ & 9,8 & 20,2 & 8,0 & 9,6 & 15,3 & 14,8 & 14,2 & 11,6 \\
\hline
\end{tabular}


Состав брызг из фильтра характеризует дисперсность кристаллов Fe в металле.

Состав пены характеризует окисленность соединений поверхности кристаллов соединения железа с алюминием возникающей при перемешивании расплава фильтром.

Состав брызг ближе по составу к пене, чем к отрафинированному металлу. Это означает, что пена имеет высокодисперсную структуру и ее частицы (менее 0,1 мм) частично проскакивают через фильтр пока не заполнится щель фильтра.

В пене содержание алюминия больше чем в съемах.

При соотношении $(\mathrm{Al} / \mathrm{Fe})_{\text {исх }}>1,6$ в расплаве содержание $\mathrm{Fe}_{\text {дрос }}$ в дроссах превышает его содержание в брызгах по уравнению:

$$
\mathrm{Fe}_{(\text {др/бр) }}=50,3 \cdot(\mathrm{Al} / \mathrm{Fe})_{\text {исх }}-67,7 \text { с корреляцией } 0,93 .
$$

В то время как при $(\mathrm{Al} / \mathrm{Fe})_{\text {исх }}<1,6$ соотношение концентраций железа в пене к содержанию железа в брызгах не меняется от $(\mathrm{Al} / \mathrm{Fe})_{\text {исх }}$.

Образующаяся на поверхности ванны пена кристаллов соединений железа с алюминием проскакивает фильтр пока зазор не уменышится заполнением более крупными кристаллами. Это значительно снижает производи-

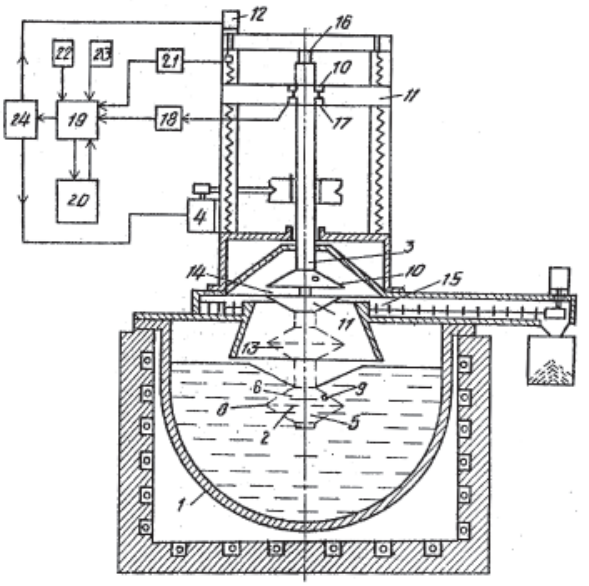

Рис. 45. Управление центрифуги.

Основные узлы: 3 - ротор; 5-фильтр;

10 - опора подшипников ротора;

17- тороидальным дифференциальным

гидравлическим датчиком давления;

18 - электрический преобразователь давления

тельность. Кинетика удаления железа из расплава цинка вступает в противоречие с кинетикой набора осадка в фильтр.

Чем полнее удаляется железо, тем меньше заполняется фильтр и с меньшей эффективностью работают механизмы центрифуги. При высоком содержании железа фильтр достаточно быстро наполняется и нет необходимости в длительном вращении.

При глубоком погружении фильтра в расплав фильтр не полностью заполняется осадком и происходит излишняя длительность работы центрифуги, окисление пены. Уровень погружения заборных окон фильтра должен быть на уровне слое пены. 
Уровень расплава в ванне понижается по мере фильтрации и требуется корректировать глубину его погружения и пополнения ванны с повторной кристаллизацией.

При низком содержании железа производительность наполнения фильтра недостаточная, т. е. фильтр не наполняется. Возникает необходимость увеличения длительности вращения фильтра в расплаве [5].

Для повышения общей производительности фильтрации путем сокращения количества циклов с недостаточно наполненной полостью фильтра предлагался [33] вариант устранения этого недостатка. Сущность изобретения в том, что с помощью дифференциального датчика измеряют силу давления вращающегося ротора фильтра центрифуги (рис. 45) на опору подшипника (рис. 46) до погружения в расплав и после подъема из расплава. Определяют прирост силы давления, сравнивают с заданным значением и регулируют длительность вращения ротора-фильтра в расплаве, причем при отрицательном значении разности повышают длительность вращения ротора-фильтра в расплаве, а при положительном значении длительность вращения ротора-

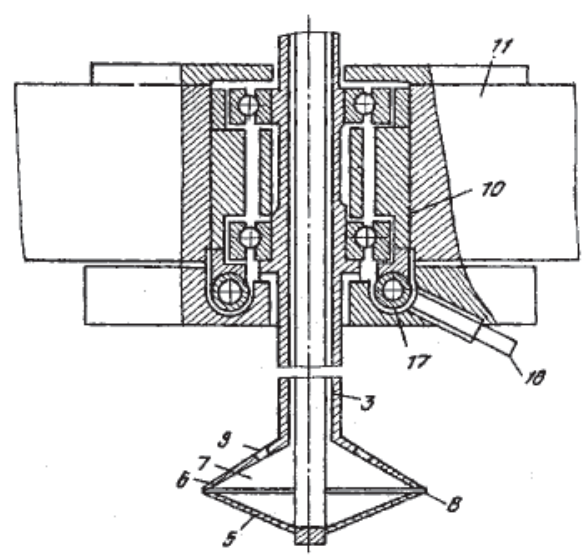

Рис. 46. Ротор с фильтром.

Основные узлы: 3 - ротор; 5 - фильтр; 10 - опора подшипников ротора; 17 - тороидальным дифференциальным гидравлическим датчиком давления; 18 - электрический преобразователь давления фильтра изменяют наоборот.

Для осуществления способа опора ротора-фильтра снабжена торроидальным дифференциальным гидравлическим датчиком давления, к которому подсоединен электрический преобразователь давления через устройство сопряжения соединено с анализатором, таймером, задатчиком и блоком управления приводами.

\section{6. Экстракция железа с алюминием из гартцинка}

Процесс очистки гартцинка от железа рассмотрим как экстракцию железа экстрагентом алюминием из расплавленного цинка. В этой системе можно рассматривать: ( $\mathrm{Zn})$-расплав; растворенное $(\mathrm{Fe})$ в цинке; 
экстрагирующий реагент $\mathrm{Al}$ с образованием дроссов в отдельную фазу как экстракта.

Дроссы представляют кристаллы малорастворимые соединения $\mathrm{Fe}_{2} \mathrm{Al}_{5} ; \mathrm{FeAl}_{3} ; \mathrm{FeZn}_{3}$ (иногда в виде пены) и по ходу процесса изменяют состав расплава. Экстракционную систему характеризует коэффициент распределения $K_{\text {рсп }}$, определяемый как отношение равновесных концентраций вещества в двух не смешивающихся фазах. Равновесные концентрации Fe в фазе расплав цинка и в фазе твердых дроссов связаны коэффициентом распределения:

$$
K_{\mathrm{pcn}}=[M]_{a} /[M]_{b}=\mathrm{Fe}_{d r} / \mathrm{Fe}_{r s} .
$$

Примем исходные обозначения: Масса железа в гартцинке = $X_{0}=M_{\mathrm{Fe}}^{\circ}$.

Масса железа в (рафинате) отрафинированном цинке $=X_{0}=M_{\mathrm{Fe}}^{\mathrm{x}}$.

Масса цинка (растворителя) в (рафинате) в отрафинированном цинке $=M_{\text {zn }}$.

Масса (экстрагирующей фазы с реагентом алюминия) $=M_{d r}$.

Масса железа в (экстракте) дроссах $=\left(X_{\mathrm{o}}-X\right)=\left(M_{\mathrm{Fe}}^{\mathrm{o}}-M_{\mathrm{Fe}}^{\mathrm{x}}\right)$.

Коэффициент распределения:

$$
\begin{gathered}
K_{\mathrm{pcп}}=\frac{\% \mathrm{Fe}_{d r}}{\% \mathrm{Fe}_{r s}}=\frac{\left(M_{\mathrm{Fe}}^{\mathrm{o}}-M_{\mathrm{Fe}}^{\mathrm{x}}\right) / M_{d r}}{M_{\mathrm{Fe}}^{\mathrm{x}} / M_{\mathrm{Zn}}} ; \\
K_{\mathrm{pcп}}=\frac{\left(M_{\mathrm{Fe}}^{\mathrm{o}}-M_{\mathrm{Fe}}^{\mathrm{x}}\right) \cdot M_{\mathrm{Zn}}}{M_{d r} \cdot M_{\mathrm{Fe}}^{\mathrm{x}}} ; \\
K_{\mathrm{pcn}} \cdot M_{d r} \cdot M_{\mathrm{Fe}}^{\mathrm{x}}=\left(M_{\mathrm{Zn}} \cdot M_{\mathrm{Fe}}^{\mathrm{o}}-M_{\mathrm{Zn}} \cdot M_{\mathrm{Fe}}^{\mathrm{x}}\right) ; \\
K_{\mathrm{pcn}} \cdot M_{d r} \cdot M_{\mathrm{Fe}}^{\mathrm{x}}+M_{\mathrm{Zn}} \cdot M_{\mathrm{Fe}}^{\mathrm{x}}=M_{\mathrm{Zn}} \cdot M_{\mathrm{Fe}}^{\mathrm{o}} ; \\
M_{\mathrm{Fe}}^{\mathrm{x}}\left(K_{\mathrm{pcn}} \cdot M_{d r}+M_{\mathrm{Zn}}\right)=M_{\mathrm{Zn}} \cdot M_{\mathrm{Fe}}^{\mathrm{o}} ; \\
M_{\mathrm{Fe}}^{\mathrm{x}}=M_{\mathrm{Zn}} \cdot \frac{M_{\mathrm{Fe}}^{\mathrm{x}}}{K_{\mathrm{pcп}} \cdot M_{d r}+M_{\mathrm{Zn}}}=M_{\mathrm{Fe}}^{\mathrm{o}} \cdot\left(\frac{M_{\mathrm{Zn}}}{K_{\mathrm{pcn}} \cdot M_{d r}+M_{\mathrm{Zn}}}\right),
\end{gathered}
$$


делим числитель и знаменатель на $M_{\mathrm{Zn}}$ получим расчетное содержание $\mathrm{Fe}$

$$
M_{\mathrm{Fe}}^{\mathrm{x}}=M_{\mathrm{Fe}}^{\mathrm{o}} \cdot \frac{1}{K_{\mathrm{pcп}} \cdot M_{d r} / M_{\mathrm{Zn}}+1},
$$

где $M_{\mathrm{Fe}}^{\mathrm{x}}-$ масса железа в отрафинированном цинке после однократного акта фильтрации при постоянном $K_{\text {рсп }}$.

Расчет ожидаемого содержания железа в отрафинированном цинке с коэффициентом разделения позволяет определить момент необходимости введения дополнительного алюминия в расплав.

В табл. 27 приведены опытные данные процесса экстракции железа с алюминием из гартцинка центробежной фильтрацией при разной концентрации алюминия по отношению к содержанию железа.

Таблица 27

Экстракция железа с алюминием из гартцинка

\begin{tabular}{|c|c|c|c|c|c|c|c|c|}
\hline \multirow{3}{*}{$\begin{array}{c}B, \\
\text { мин }\end{array}$} & \multicolumn{3}{|c|}{ Расплав гартцинка } & \multicolumn{3}{|c|}{ Дроссы от фильтрации } & \multirow{3}{*}{$K_{\text {pacn }} \mathrm{Fe}_{d r} / \mathrm{Fe}_{r s}$} & \multirow{3}{*}{$\mathrm{Zn} / \mathrm{Fe}$ dros } \\
\hline & \multicolumn{2}{|c|}{$\begin{array}{c}\text { состав pac- } \\
\text { плава }\end{array}$} & \multirow{2}{*}{$(\mathrm{Al} / \mathrm{Fe})_{r s}$} & \multicolumn{2}{|c|}{ состав дроссов } & \multirow{2}{*}{$(\mathrm{Al} / \mathrm{Fe})_{d r}$} & & \\
\hline & $\mathrm{Al}, \%$ & $\mathrm{Fe}, \%$ & & $\mathrm{Fe}, \%$ & $\mathrm{Al}, \%$ & & & \\
\hline 0,7 & 0,09 & 0,53 & 0,35 & 5,88 & 1,39 & 0,49 & 11,0 & 15,8 \\
\hline 1,4 & 0,08 & 0,49 & 0,34 & 5,88 & 1,39 & 0,49 & 12,0 & 15,8 \\
\hline 2,1 & 0,07 & 0,44 & 0,32 & 5,88 & 1,39 & 0,49 & 13,3 & 15,8 \\
\hline 2,8 & 0,06 & 0,39 & 0,30 & 5,88 & 1,39 & 0,49 & 15,1 & 15,8 \\
\hline 3,5 & 0,05 & 0,36 & 0,28 & 4,36 & 1,14 & 0,54 & 12,1 & 21,7 \\
\hline 4,2 & 0,04 & 0,33 & 0,25 & 4,36 & 1,14 & 0,54 & 13,2 & 21,7 \\
\hline 4,9 & 0,03 & 0,31 & 0,23 & 4,14 & 1,02 & 0,51 & 13,4 & 22,9 \\
\hline 5,6 & 0,03 & 0,29 & 0,21 & 4,14 & 0,96 & 0,48 & 14,3 & 22,9 \\
\hline 6,3 & 0,03 & 0,28 & 0,20 & 3,86 & 0,90 & 0,48 & 13,7 & 24,7 \\
\hline 7 & 0,02 & 0,26 & 0,19 & 3,86 & 0,84 & 0,45 & 14,7 & 24,7 \\
\hline 7,7 & 0,02 & 0,25 & 0,17 & 3,33 & 0,78 & 0,48 & 13,3 & 28,8 \\
\hline 8,4 & 0,02 & 0,22 & 0,14 & 4,31 & 0,72 & 0,35 & 19,5 & 22,0 \\
\hline 9,1 & 0,01 & 0,21 & 0,13 & 4,31 & 0,66 & 0,32 & 21,0 & 22,0 \\
\hline 9,8 & 0,01 & 0,19 & 0,13 & 4,28 & 0,36 & 0,17 & 22,9 & 22,3 \\
\hline 10,5 & 0,01 & 0,18 & 0,12 & 4,28 & 0,36 & 0,17 & 23,8 & 22,3 \\
\hline 11,2 & 0,01 & 0,17 & 0,12 & 4,28 & 0,36 & 0,17 & 25,0 & 22,3 \\
\hline 11,9 & 0,01 & 0,17 & 0,12 & 4,28 & 0,36 & 0,17 & 25,2 & 22,3 \\
\hline
\end{tabular}


Коэффициент распределения вначале фильтрации близок к постоянному, но в целом растет по линейному уравнению:

$$
K_{\mathrm{pcr}}=0,8 \cdot \min +9,5 \text { с корреляцией } 0,85,
$$

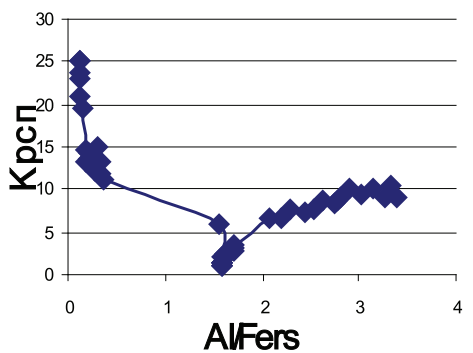

Pис. 47. Влияние $(\mathrm{Al} / \mathrm{Fe})_{r s}$ на $K_{p c n}-$ коэффициент распределения где min - длительность фильтрации от начала, в мин.

Это свидетельствует, что между фазами идет взаимодействие конкурирующих соединений $\mathrm{Fe}_{2} \mathrm{Al}_{5} ; \mathrm{FeAl}_{3}$ и $\mathrm{Zn}_{2} \mathrm{Fe}_{3}$

Опыты показали, что с увеличением отношения атомной концентрации алюминия к железу $(\mathrm{Al} / \mathrm{Fe})_{\mathrm{rs}}$ коэффициент распределения вначале снижается до 1,6 затем повышается (рис. 47) на участках по уравнениям:

$K_{\text {рсп }}=27,4-50,44 \cdot(\mathrm{Al} / \mathrm{Fe})_{r s}$ с корреляцией 0,68 при $(\mathrm{Al} / \mathrm{Fe})_{r s}>0,1<0,4$;

$K_{\mathrm{pcr}}=15,15-7,52 \cdot(\mathrm{Al} / \mathrm{Fe})_{r s}$ с корреляцией 0,94 при $(\mathrm{Al} / \mathrm{Fe})_{r s}>0,4<1,6$;

$K_{\text {рсп }}=4,21 \cdot(\mathrm{Al} / \mathrm{Fe})_{r s}-3,32$ с корреляцией 0,84 при $(\mathrm{Al} / \mathrm{Fe})_{r s}>1,6$.

Обработка подобных опытов при разной концентрации алюминия в расплаве и разной температуре показала, что коэффициент распределения увеличивается с повышением температуры [34].

Кроме того с увеличением $(\mathrm{Al} / \mathrm{Fe})_{r s}$ возрастает доля алюминия в дросcax $(\mathrm{Al} / \mathrm{Fe})_{d r}$ по уравнению:

$$
(\mathrm{Al} / \mathrm{Fe})_{d r}=0,51 \cdot(\mathrm{Al} / \mathrm{Fe})_{r s}+0,32 \text { с корреляцией } 0,84 .
$$

Поэтому с увеличением $(\mathrm{Al} / \mathrm{Fe})_{\text {rs }}$

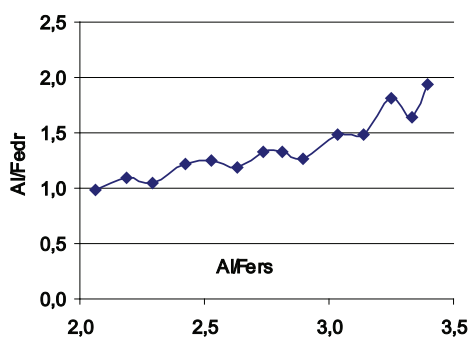

Рис. 48. Влияние $(\mathrm{Al} / \mathrm{Fe})_{r s} \mathrm{Ha}(\mathrm{Al} / \mathrm{Fe})_{d r}$ снижается относительный выход цинка $\mathrm{Zn} / \mathrm{Fe}$ в дроссы по уравнению:

$$
\begin{gathered}
(\mathrm{Zn} / \mathrm{Fe})=20,63-3,79 \cdot(\mathrm{Al} / \mathrm{Fe})_{r s} \\
\text { с корреляцией } 0,65 .
\end{gathered}
$$

С повышением температуры фильтрации снижается выход цинка с осадком дроссов. Это можно объяснить растворением мелких кристаллов, снижения вязкости расплава и изменения фазового состава. 


\section{7. Фидьтрации гартцинка в слое алюминиевой пены}

Полупромышленные результаты [5] подтверждают эффективность влияния отношения $(\mathrm{Al} / \mathrm{Fe})_{\text {исх }}>1,6$ (пл. 6,7) в сравнении с плавками (пл. $1-5)$. При исходном соотношении $(\mathrm{Al} / \mathrm{Fe})_{\text {ат }}>1,6$ (пл. 7) потребовалась начальная температура кристаллизации $690^{\circ} \mathrm{C}$.

Высокая температура начальной кристаллизации (пл. 7) повышает производительность и снижает выход цинка в дроссы. Высокий избыток алюминия (пл. 6) снижает потери цинка с дроссами, но и значительно снижает производительность.

Особенность процесса в значительном избытке алюминия, расслаивания пены и перекристаллизации ее без перемешивании при повышенной температуры. Поэтому разрабатывался вариант фильтрации гартцинка с избытком алюминия без введения инертного материала.

В котле расплавлено 20 кг гартцинка, содержащего 1,6\% железа растворено 0,6 кг алюминия с повышением температуры до $740^{\circ} \mathrm{C}$. Расплав охлажден до $670^{\circ} \mathrm{C}$ без перемешивания для расслаивания пены и кристаллизации соединений железа с алюминием в пене без окисления. Плавки при температурах выше $600^{\circ} \mathrm{C}$ проводили на центрифуге, в которой использовали тарели с борированной поверхностью.

Расплав исходного гартцинка нагревают до $700-740^{\circ} \mathrm{C}$ и вмешивают в течение 20-30 мин алюминий в соотношении $0,8-1,4 \%$ на $1 \%$ железа. Затем добавляют алюминий с избытком до общего расхода 1,9-3,9\% от веса гартцинка, перемешивают и расплав охлаждают до температуры $650-690^{\circ} \mathrm{C}$ в течение 30-40 мин для всплывания кристаллов $\mathrm{FeAl}_{3}$ из цинка в слой алюминия. Фильтр погружают на уровень слоя алюминиевой пены на расплаве и приводят во вращение для вылавливания кристаллов $\mathrm{FeAl}_{3}$ из слоя легкого алюминиевого слоя с минимальным диспергированием легкой алюминиевой пены в плотной ванне расплава цинка. При этой температуре отделяют железисто-алюминиевые дроссы центробежной фильтрацией погружением фильтра в слой пены алюминия на поверхности расплава цинка.

Затем перемешивают расплав с охлаждением до $470-440{ }^{\circ} \mathrm{C}$ и погружением вращающегося фильтра на дно ванны отфильтровывают всплывшие образовавшиеся кристаллы остатков железа в твердом избыточном алюминии.

Поэтапное вмешивание алюминия создает условия образование соединение железа с алюминием вместо соединения железа с цинком и снижаются на 30-50\% потери цинка с дроссами. Получают рафинированный цинк, содержащий 0,2\% железа; 0,7\% алюминия, отходы в виде 
осадка железо алюминиевых кристаллов с содержанием 36,3\% железа; $52,7 \%$ алюминия, $11 \%$ цинка и оборотный осадок алюминиевой пены, содержащей 2,5\% железа, $12,4 \%$ алюминия.

Фильтрация проведена погружением фильтра на уровень алюминиевой пены. По мере отделения кристаллов дроссов температуру расплава снижается и фильтрация проводится погружением фильтра в расплав гартцинка. Сначала охлажденный расплав отфильтрован при температуpe $500^{\circ} \mathrm{C}$ а потом при $440^{\circ} \mathrm{C}$. В табл. 28 приведен баланс опыта.

Таблица 28

Баланс фильтрации гартцинка в слое алюминиевой пены

\begin{tabular}{|c|c|c|c|c|c|c|c|c|}
\hline & $T,{ }^{\circ} \mathrm{C}$ & $\begin{array}{c}\text { Bec, } \\
\mathrm{K \Gamma}\end{array}$ & $\begin{array}{c}\text { Процент } \\
\mathrm{Fe}\end{array}$ & $\begin{array}{c}\text { Вых., } \\
\%\end{array}$ & $\begin{array}{c}\text { Процент } \\
\text { Al }\end{array}$ & $\begin{array}{c}\text { Вых., } \\
\%\end{array}$ & $\mathrm{Zn} / \mathrm{Fe}$ & $(\mathrm{Al} / \mathrm{Fe}) \mathrm{at}$ \\
\hline \multicolumn{9}{|l|}{ Загружено } \\
\hline Гартцинк & & 20 & 1,6 & & & & & \\
\hline Алюминий & & 0,6 & & & & & & \\
\hline Итого расплав & & 20,6 & 1,55 & & & 2,91 & & 3,86 \\
\hline \multicolumn{9}{|l|}{ Получено } \\
\hline 1-Al-Fe-дрос & 670 & 0,53 & 21,10 & 34,9 & 15,3 & 46,5 & 3,0 & 1,50 \\
\hline 2-Al-Fe-дрос & 500 & 2,30 & 7,50 & 53,9 & 4,0 & 13,5 & 11,8 & 1,11 \\
\hline 3-Al-Fe-дрос & 440 & 1,00 & 2,51 & 7,8 & 1,5 & 2,5 & 38,3 & 1,21 \\
\hline Цинк & & 16,57 & 0,08 & 2,4 & 0,5 & 36,6 & & \\
\hline
\end{tabular}

Среднее содержание железа в общих дроссах - 8,1. Среднее содержание цинка в дроссах - 87,0; Общий выход дроссов - 18,6, а средний выход цинка в дроссы, так называемые потери цинка в дроссы на единицу удаленного железа - 10,8; Осадок алюминиевой пены используют как оборотный алюминий [4].

Способ проверен только на лабораторной установке из-за сложности организации цикличности стадий на одном оборудовании.

Однако, для широкого применения варианта требуется использовать тарели промышленных центрифуг с борированным покрытием.

\section{8. Промышленные испытание центробежной регенерации цинка из гартцинка}

Полупромышленные испытания проводились на центрифуге ПАВФС-650 разработанной для фильтрации олова. В рафинировочный электрообогреваемый котел диаметром 1,5 м загружался гартцинк до 15 т, 
тремя приемами по мере расплавления каждой загрузки, и перемешивался при температуре $600^{\circ} \mathrm{C}$. На котел с вентиляционным кольцом устанавливалась центрифуга ПАФВС-650 (рис. 49). При температуре расплава $520^{\circ} \mathrm{C}$ проводилась центробежная фильтрация в автоматическом режиме при скорости вращения 280 об/мин.
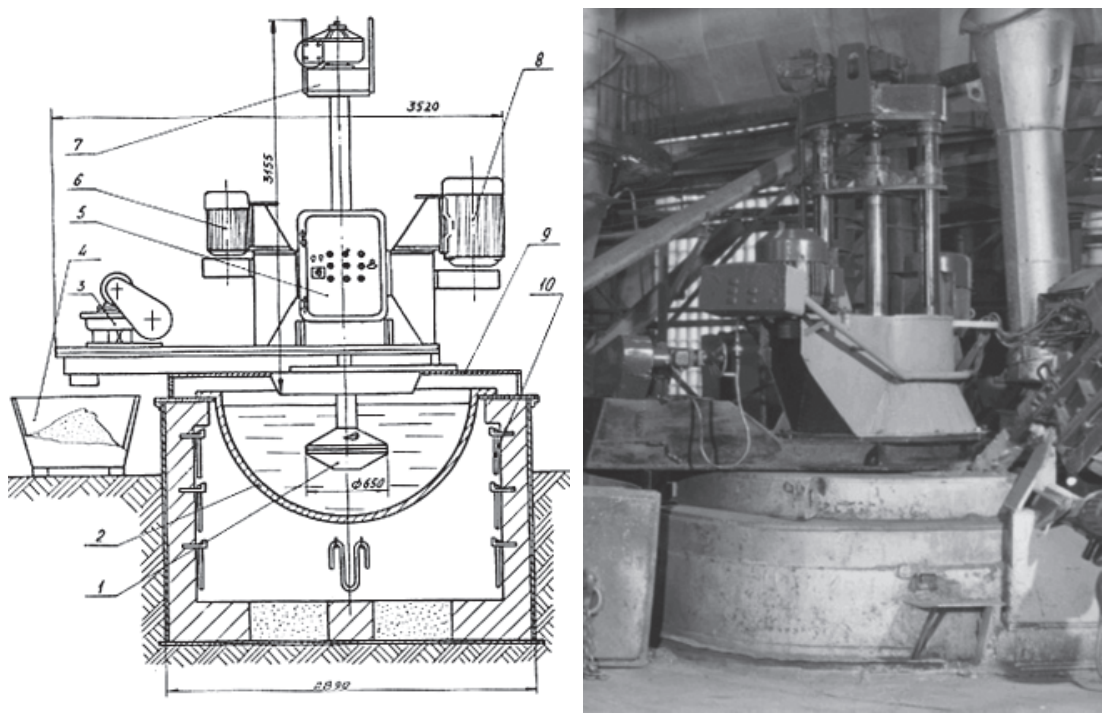

Рис. 49. Общий вид иентрифуги ПАФВС-650 и фото.

Основные узлы: 1 - фильтр; 2 - рафинировочный котел; 3 - редуктор транспортера дроссов; 4 - кюбель дроссов; 6- двигатель для отжима съемов; 7 - механизм подъема ротора; 8- двигатель вращения фильтра; 9 - бортовой отсос (вентиляция)

В каждом цикле после наполнения дроссами фильтр приподнимался над расплавом скорость вращения фильтра увеличивалась до 1200 об/мин на 3 мин. Фильтрация расплава от кристаллов соединений железа проводилось в течение 1-2 часов до прекращения выделения сыпучих дроссов. Снято 3,5 т дроссов и из-за снижения уровня металла догружено 5,0 т гартцинка. Металл перемешан мешалкой и циклы фильтрации продолжены. Для повышения уровня металла еще догружено 4,0 т гартцинка. Фильтрация продолжена до прекращения выделения сыпучих дроссов при охлаждении расплава от температуры 520 до $450^{\circ} \mathrm{C}$ и получено 3,8 т дроссов. После этого металл нагрет до $520^{\circ} \mathrm{C}$ и разлито 10 т отрафинированного цинка. В табл. 29 приведен баланс компонентов при фильтрации гартцинка. 
Таблица 29

Баланс полупромышленной регенерации цинка из гартцинка с ванн цинкования завода НМЗ

\begin{tabular}{|c|c|c|c|c|c|c|c|}
\hline \multirow{2}{*}{ Стадии плавки } & \multirow{2}{*}{ Bec, $\mathrm{T}$} & \multicolumn{3}{|c|}{ Анализ, \% } & \multirow{2}{*}{$\mathrm{Fe}, \mathrm{K \Gamma}$} & \multirow{2}{*}{$\mathrm{Al} / \mathrm{Fe}$} & \multirow{2}{*}{$\begin{array}{c}\text { Процент Fe, } \\
\text { выход }\end{array}$} \\
\hline & & $\mathrm{Fe}$ & $\mathrm{Al}$ & $\mathrm{Zn}$ & & & \\
\hline Загружено: гартцинк & 24 & 2,32 & 0,26 & 95,4 & 557 & 0,11 & 100 \\
\hline \multicolumn{8}{|l|}{ Получено } \\
\hline Дроссы при 520 & 3,5 & 7,4 & 1,4 & 89 & 259 & 0,19 & 46,5 \\
\hline Дроссы при 480 & 3,8 & 4,6 & 0,2 & 93,1 & 175 & 0,04 & 31,4 \\
\hline Дроссы & 3 & 3 & 0,2 & 94,7 & 90 & 0,07 & 16,2 \\
\hline Цинк разлит & 10 & 0,08 & 0,03 & 97,8 & 8 & 0,38 & 1,4 \\
\hline Цинк в котле & 3,7 & 0,08 & 0,03 & 97,8 & 2,96 & 0,38 & 0,5 \\
\hline
\end{tabular}

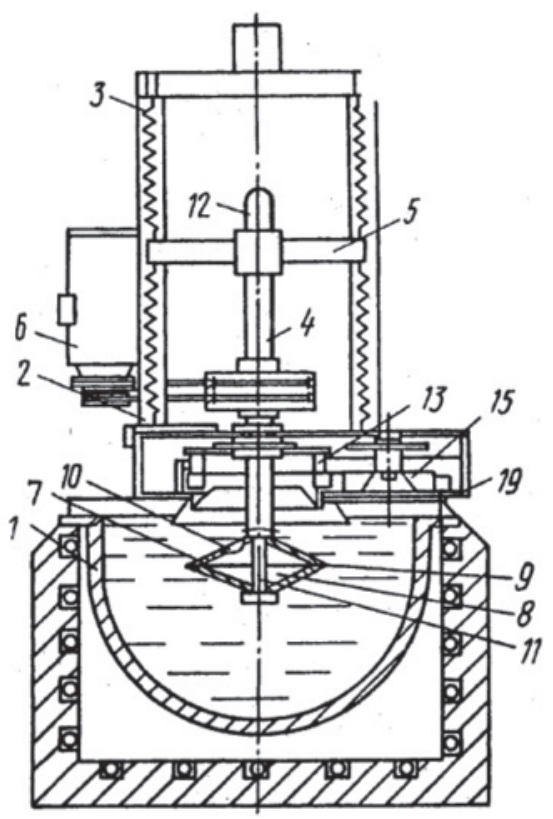

Рис. 50. Центрифуга ЦП-400.

Основные узлы: 4 - ротор; 7 - фильтр; 13 - основной барабан сбора;

15 - дополнительный барабан разгрузки осадка

Узким местом является подготовка ванны расплавленного металла. С учетом мощности котла и длительности плавления расход электроэнергии 540 кВт•ч на тонну гартцинка.

Основной особенностью полупромышленных плавок является значительное снижение уровня металла в ванне по мере отделения дроссов, что препятствовало продолжению фильтрации. Поэтому периодически проводилась догрузка ванны исходным металлом. Повторная кристаллизация расплава снижало общую производительность.

Производство горячего цинкования размещалось на крупных металлургических заводах и технологи больше озабочены сохранением качества продукции, чем регенерации цинка из отходов. Сохранялась практика 
реализации всех отходов предприятиям вторичных металлов. Поэтому разработан и изготовлен облегченный с 7 до 2 т вариант центрифуги ЦП-400 для малых предприятий (рис. 50).

Полупромышленные испытание фильтрации гартцинка Орловского сталепрокатного завода ОСПЗ проводили центрифугой ЦП-400.

Центрифуга ЦП-400 [35] снабжена дополнительным барабаном с лопатками, кинематически связанными с основным скребковым транспортером, причем оси основного транспортера с лопатками и дополнительным барабаном с лопатками размещены с образованием общего сегмента, ширина которого больше лопаток основного транспортера. В последующем центрифуга ЦП-400 поставлена дочерней фирме ОСПЗ, занимающаяся переработкой отходов цинка. В табл. 30 показаны результаты полупромышленных испытаний переработки железистого цинка, поставляемых с разных заводов [5].

Таблица 30

Результаты полупромышленных испытаний фильтрации гартцинка различных заводов

\begin{tabular}{|c|c|c|c|c|c|c|c|}
\hline Происхождение & \multicolumn{2}{|c|}{$\mathrm{H}$} & \multicolumn{2}{|c|}{ Ч } & $\mathrm{O}$ & Б & Я \\
\hline Номер плавки & 1 & 2 & 3 & 4 & 5 & 6 & 7 \\
\hline Загружено, тн & 15,4 & 13,8 & 18,6 & 16 & 24,3 & 13,8 & 20,6 \\
\hline Содержание, \% Fe в гартцинке & 2,89 & 2,89 & 2,23 & 2,23 & 2,32 & 3,45 & 1,77 \\
\hline$(\mathrm{Al} / \mathrm{Fe})_{\text {ат }}$ в загрузке & 0,26 & 0,26 & 0,29 & 0,29 & 0,23 & 3,32 & 1,95 \\
\hline Температура кристализации, ${ }^{\circ} \mathrm{C}$ & 550 & 625 & 560 & 593 & 600 & 600 & 690 \\
\hline Скорость кристаллизации, ${ }^{\circ} \mathrm{C} / ч$ & 15,2 & 16 & 16 & 16,9 & 15 & 30 & 11 \\
\hline$T,{ }^{\circ} \mathrm{C}$, фильтрации & 470 & 500 & 510 & 500 & 470 & 460 & 580 \\
\hline $\mathrm{Fe}, \%$, в отфильтрованном металле & 0,32 & 0,36 & 0,21 & 0,33 & 0,16 & 0,24 & 0,13 \\
\hline Выход дроссов, \% & 38,6 & 21,7 & 27,4 & 35,3 & 41,5 & 33,4 & 13 \\
\hline Содержание \% Fедрос & 6,9 & 5,39 & 6,19 & 5,38 & 5,35 & 9,8 & 12,6 \\
\hline Выход \% Fe в дроссы & 91,5 & 78,9 & 76 & 85,1 & 95,9 & 95 & 94,8 \\
\hline$(\mathrm{Al} / \mathrm{Fe})_{\text {ат }}$ в дроссах & 0,23 & 0,37 & 0,23 & 0,23 & 0,16 & 1,20 & 1,31 \\
\hline$(\mathrm{Zn} / \mathrm{Fe})$ в дроссах & 13,2 & 16,9 & 27,4 & 32,3 & 17,6 & 8,6 & 6,33 \\
\hline Производительность фильтра, кг/мин & 11,2 & 9,72 & 12,4 & 12,3 & 10,7 & 6,8 & 10,3 \\
\hline Общая производительность, т/ч & 1,3 & 2,7 & 2,7 & 2,1 & 1,5 & 1,2 & 4,7 \\
\hline
\end{tabular}

Примечание. Происхождение гартцинка: $\mathrm{H}$ - Новосибирский металлургический завод им. Кузьмина; Ч - Череповецкий сталепрокатный завод; О - Орловский сталепрокатный завод; Б - Бельгия, завод Balen; Я - Япония, корпорация NKK. 
В дальнейшем промышленную переработку гартцинка с ванн цинкования, поставляемых с заводов, использующих горячее цинкование, проводились на запасном оборудовании цеха рафинирования олова.

В целом во время промышленых испытаний ценробежной фильтрации гартцинка НМЗ и ЧСПЗ переработано 133 т гартцинка и получено 53,4 т цинка, который возвращен поставщику для загрузки в ванну цинкования. Регенерированный цинк не ухудшил процесс горячего цинкования.

Центробежная фильтрация гартцинка с исходным содержанием 2-5\% железа, 0,2-5\% алюминия, 0,2-0,3\% в процессе снижения температуре расплава с 520 до $450{ }^{\circ} \mathrm{C}$ получен цинк с содержанием 0,08\% железа. Извлечение цинка в металл 43-53\%. Выход дроссов составил 40-50\% с содержанием железа - 5-7\%, цинка - 83-95\%. Выход цинка в фильтр остатки $3,5 \%$ на процент удаляемого железа. Производительность фильтрации 1-2 т дроссов в час [30].

Совмещение работ по рафинированию олова и фильтрации гартцинка осложняет организацию работ с загрязнением аспирационных пылей и поэтому работы прекращены.

В цинковой ванне накапливается осадок соединения железа, который еженедельно вычерпывают на ванны. После накапливания отходов в блоках их реализуют предприятиям переработки вторичных металлов. Проблем по реализации отходов цинка не возникает на фоне роста потребления и производства цинковых белил. Поэтому несмотря на приемлемые показатели регенерации гартцинка отечественные и зарубежные предприятия не склонны нести затраты на приобретение центрифуг.

\section{9. Обзор вариантов очистки расплава ванны центробежной фильтрацией}

В технологии цинкования периодически возникает необходимость ремонта ванны с полной разгрузкой 200 т цинка с помощью насоса в непрерывном режиме. Для этой стадии технологии применима заливная центрифуга. Для условий полной разгрузки ванны цинкования разработана [36] заливная центрифуга (рис. 51).

Центрифуга содержит ротор 1 с закрепленной на нем нижней тарелью 2, а соосно с ним на валу 3 закреплена верхняя тарель 4. Тарели 3 и 4 соединенные большими основаниями образуют фильтрующую щель 5 [36]. Густую суспензию порциями заливают через окно в крышке 6 и через окна между крестовиной 8 поступает в полость образуемую тарелями 3, 4. После заполнения этой полости кристаллами щель 5 забивается. Под действием центробежных сил происходит расслоение суспензии и жидкая фаза продавливается через пористые стенки конусов 11 
и далее через окно 10 и по каналу между крышкой 6 и тарелью 4 выбрасывается в наклонный лоток 7. После прекращения сброса жидкой фазы через щель 5 ротор 1 с фильтром опускается до упора в станину. При этом фильтр опускается до положения 11 , тарели 3, 4 раскрываются и осадок выбрасывается по лотку 12.

Заливная центрифуга позволяет в непрерывном режиме отфильтровать расплавленный гартцинк. Однако, в этом варианте без циркуляции расплава через фильтр получаемый цинк не удовлетворяет требованиям кондиции по содержанию железа.

Существующая практика периодической разгрузки осадка с ванны с разливкой в блоки трудоемкий

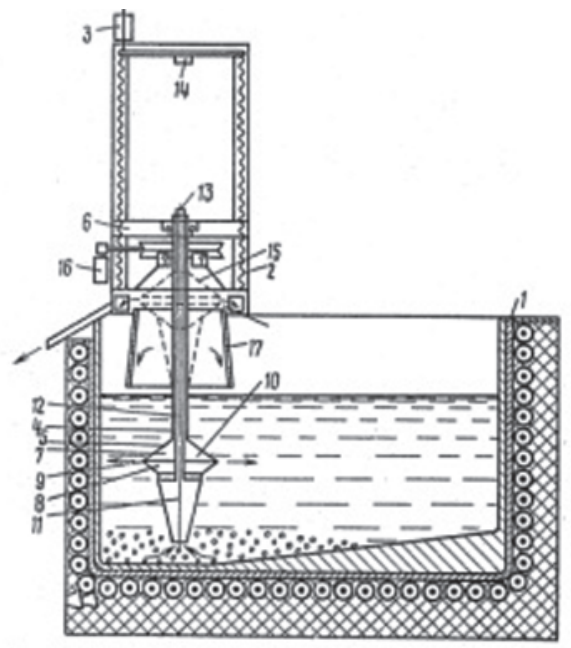

Рис. 52. Центрифуга очистки расплава в ванне. Основные узлы: 1 - ванна цинкования; 6-механизм погружения; 8- фильтр; 11 - конус всасывания

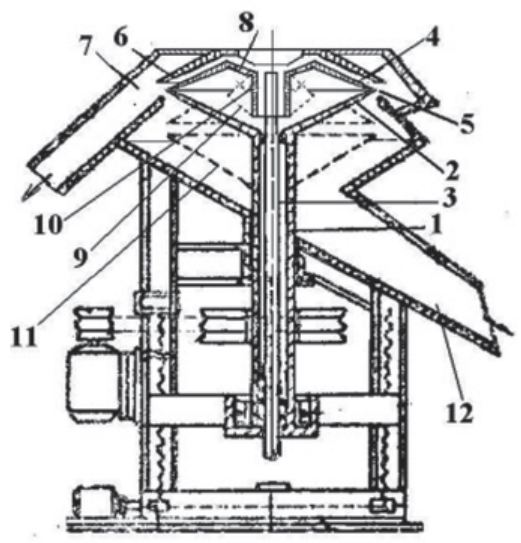

Рис. 51. Центрифуга с заливкой расплава. Основные узлы: 6 - полость фильтра; 11 - конус с пористой стенкой; 15 - кольцевой сборник жидкого; 23 - кольцевой сборник твердого

процесс и со снижением производительности.

Поэтому предлагалось удаление соединений железа проводить непосредственно на ванне цинкования с помощью центрифуги [37]. Для этого нижняя тарель соединена с коническим соплом, а внутренняя поверхность сопла выполнена в виде спирали.

Суспензия расплава с твердыми примесями вовлекается через сопло 11 конуса всасывания вполость фильтра 10 . Твердый осадок расплава под действием центробежных сил прижимается к впадине винтовой спирали 11, перемещается вверх на необходимую высоту до полости 10 фильтра 5. 


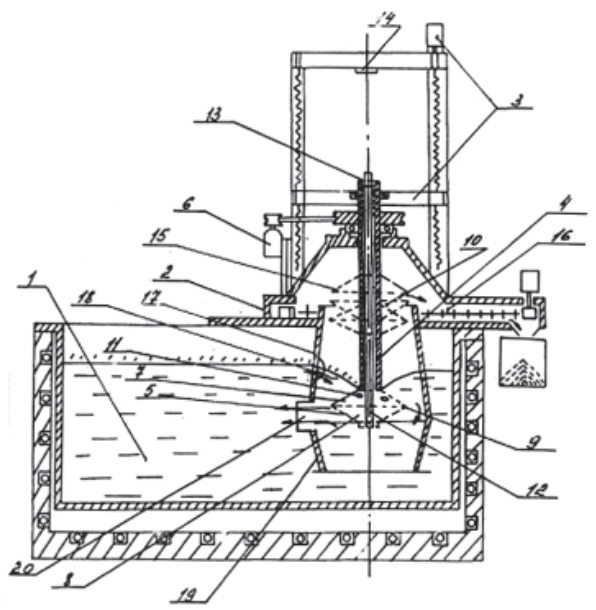

Рис. 53. Центрифуга очистки расплава в ванне. Основные узлы: 8- нижняя тарель;

9 - спиральный шнек; 11 - конусообразная обечайка; 17 - экран сбора брызг; 18 - окна снизу 17

Брызги жидкого расплава стекают по конусу отбойника 17 в ванну 1. После сушки осадка фильтр 5 приподнимается в положение 15 и осадок под действием центробежных сил выбрасывается вне ванны.

Недостатком конструкции оказалось перемешивание слоем металла от струй выбрасываемого цинка из щели фильтра.

В последующем эта центрифуга усовершенствована [38] тем, что в полости экрана 17 выполнены окна 18 (рис. 53).

В полости экрана 17 создается поток металла в виде воронки, за счет чего дроссы «плывут» по поверхности металла ванны к окнам 18 и через них внутрь экрана 17. При вращении фильтра 5 в расплаве дроссы с поверхности расплава захватываются заборными окнами 11 внутрь полости фильтра. Жидкий расплав продавливается через фильтрующую щель 9 и выбрасывается в расплав на стенку конусного экрана 17. Металл отражается от стенки конусного экрана 17, вращаясь, перемешается вниз к большому основанию конусов экрана 17, 19 и через тангенциально направленный патрубок 20 выбрасывается вдоль стенки ванны 1. После накопления твердых кристаллов в полости 10 фильтр не прекращая вращения. приподнимается происходит «досушка» осадка от жидкой фазы. После сушки осадка фильтр 5 приподнимается в положение 15, где механизмом сжатия 13 и упора 14 тарели 7, 8 раскрываются и осадок под действием центробежных сил выбрасывается на транспортер 16.

Недостатком этой конструкции в недостаточном захвате донного железистого осадка.

По другому варианту центрифуги (рис. 54) нижняя тарель фильтра также снабжена винтовым спиральным шнеком 9. Коаксиально снаружи шнека 9 расположена конусообразная обечайка 14 , жестко закрепленная на корпусе 2 центрифуги [39]. 
Суспензия расплава с твердыми примесями вовлекается спиральным шнеком 9 по обечайке 14 в фильтр 5. Под действием центробежных сил жидкий расплав продавливается через фильтрующую щель 7 и выбрасывается на отражатель 13, а твердые кристаллы остаются в полости фильтра 5. Периодически включается привод 17, траверса 16 поднимает вращающийся в подшипнике 15 ротор 4 до тех пор, пока механизм 19 прижмется к упору 20, сожмет пружину 11 и нижняя тарель 6 отожмется от верхней тарели фильтра 5 в положении 18. Из раскрытого фильтра 5 осадок выбрасывается в камеру 12 транспортера [40].

Несмотря на разработку конструкций аппаратов регенерации гартцинка в ваннах цинкования в производстве сохранилась практика периодической разгрузки ванн. Затем разгруженный гартцинк в блоках реализовался предприятиям перерабатывающих вторичные металлы.

\subsection{0. Переработка окисленного порошка цинка центробежной фильтрацией}

Для защиты от коррозии стальные металлоконструкции и магистральные трубопроводы монтируют из оцинкованных труб, покрытых горячим цинкованием.

В последнее время интенсивно развивается компактное газотермическое цинкование для антикоррозионных покрытий [41]. Газотермическое цинкование является эффективным методом поверхностной обработки металлов. Газотермическое напыление заключается в распылении струей воздуха или горячего газа расплавленного порошка цинка. Нанесенные этим методом цинковые покрытия применяются, главным образом, для защиты от коррозии строительных конструкции, труб, используемых 
в судостроении, при строительстве теплотрасс, технологических трубопроводов и резервуаров в химической, нефтехимической и нефтеперерабатывающей промышленности. Преимущества газотермического напыления цинка в том, что можно осуществлять цинкование строительных металлоконструкций на месте эксплуатации [42].

При монтаже и эксплуатации оцинкованных строительных конструкций образуются узлы с нарушенным цинковым покрытием. Для устранения возникших дефектов удобно применение ручных аппаратов газотермического напыления.

Недостатки газотермического напыление цинка:

- Более высокая стоимость по сравнению с другими методами цинкования.

- Неравномерность толщины газотермического покрытия на обрабатываемой поверхности.

- Коэффициент полезного использования порошка может составлять от 50 до $90 \%$.

- Покрытие получается пористым и нуждается в дополнительной лакокрасочной обработке. Это объясняется окисленностью поверхности цинкового порошка, что ведет к неполному слипанию частиц (чешуйками).

Обычно цинковый порошок получают распылением расплава. Совместно с институтом теплофизики СО РАН разработана и освоена установка производства порошков легкоплавких металлов [43].

Установка (рис. 55) содержит тигель 2 для расплава с выпускным приспособлением, камеру 1, распылительное сопло 7. Камера снабжена площадкой растекания струи 6, установленная коаксиально распылительному соплу 7. Выпускное приспособление имеет сифонный канал и выполнено в виде напорной трубки 4 из коаксиально сдвоенных наружной 15 и внутренней трубок 14, соединенных вместе в нижней части. В верхней части наружная трубка подсоединена к источнику тока, внутренняя трубка соединена с сифонным каналом посредством конусного полого клапана 3. В нижней части напорная трубка 4 выполнена в виде калиброванного отверстия 5 .

Конструкция позволяет сохранить температуру распыляемого металла в точке распыления и стабилизировать фракционный состав порошка.

Максимальную долю необходимой фракции порошка регулируют зазором щели у распыляемого сопла, давлением распыляемого газа и температурным перепадом от точки плавления металла. Порошок цинка распыляется при температуре $470^{\circ} \mathrm{C}$ с зазором щели сопла $0,1-0,3$ мм давлением азота 2-3 ат. 

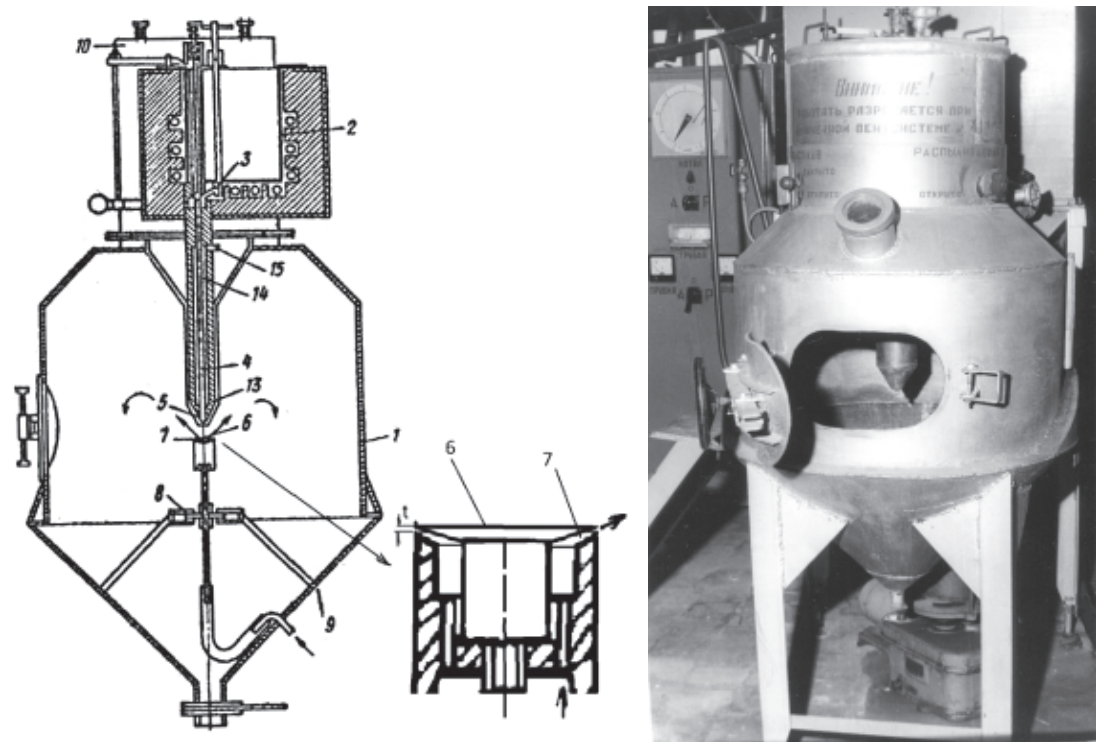

Рис. 55. Схема установки производства порошка, фото.

Основные узлы: 3 - затвор подачи расплава; 4 - гидравлический столб жидкого металла; 5 - нипель слива металла; 6, 7- сопло с зазором подачи газа в виде съемного узла; 14, 15 - коаксиальные трубки для обогрева канала металла

В отличие от радиопромышленности в технологии цинкования напылением применяются крупные порошки фракции 40-100 мкм. Для сортировки распыленных порошков используются сепараторы различной конструкции в зависимости от их реологических свойств (текучести). Для распылительной установки разработан сепаратор (рис. 56) металлических порошков [44]. Внутри цилиндрической камеры 5 сепаратора с крышкой 6, обтянутой сеткой 7, коаксиально установлен с возможностью вращения полый вал 10 с Г-образной трубкой 11. Над крышкой 6 с зазором 8 установлен отражательный конус 9. Нижний конец вала 10 соединен с патрубком подачи воздуха. Патрубок 18 для отсоса пылегазового потока расположен тангенциально камере 5 в ее полости. Загрузочное приспособление 2 расположено над крышкой 6. Разгрузочные приспособления 3 и 4 расположены в нижней части камеры 5. Металлический порошок насыпается на сетку 7. Струи воздуха, выбрасываемые через перфорации в трубке 11, продувают сетку 7, перемещают порошок к разгрузочной щели в приспособление 3. Мелкие частицы движутся с отсасываемым воздухом по окружности и ссыпаются 


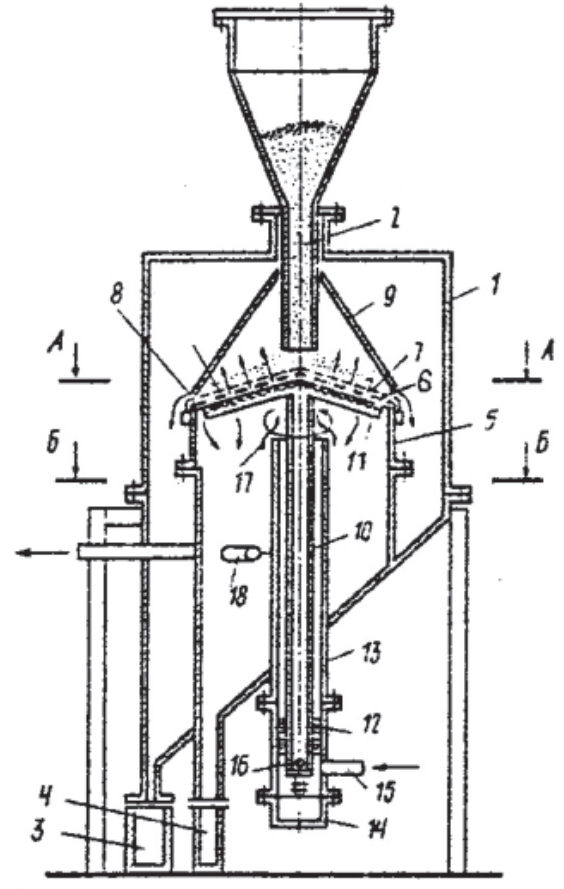

Рис. 56. Схема установки сепарации металлических порошков в приспособление 4. Для многократного возврата порошка на сетку 7 над крышкой 6 установлен отражательный корпус 9.

Установка позволяет отделять от зернистого металлического порошка пылевидную фракцию, которая снижает качество напыления из за повышенной окисленности.

Влияние окисленности порошков на качество изделий изучается и в других отраслях. В работе [45] исследованием показано, что фракция 0,05 мм порошка содержит кислорода в 10 раз больше, чем фракция $+0,1$ мм и делается вывод об целесообразности использования порошка, распыленного азотом или аргоном.

В работе [46] приведены исследования металлических порошков методом рентгеновской фотоэлектронной спектроскопией (РФЭС), выполненных

в институте катализа СО РАН, где показано, что окислению подвержен поверхностный слой 1-2 мкм частиц порошка. Порошок полученный измельчением в 1,5 раза менее окисленный, чем распыленный в азоте и в 5 раз менее окисленный, чем распыленный на воздухе.

Такой мало окисленный порошок фракции 45 мк получается измельчением зернистого сыпучего дросса от центробежной фильтрации гартцинка [47].

Дроссы, получаемые цнтробежной фильтрацией целесообразно называть фильтростатками, так как они значительно отличаются малой окисленностью и зернистостью. Ранее в разделе 4.6 показано, что кристаллы фильтростатка покрыты слоем 2,2 мкм окисла, что составляет $0,19 \%$ кислорода в порошке.

В лаборатории Алхимова А.П. института ИТПМ СО РАН разработан способ и аппарат газодинамического напыления изделий цинковым 
порошком [48]. Порошок цинка менее 50 мкм под давлением воздуха 1,2-1,6 МПа, разгоняется в сверхзвуковом сопле до 600 м/с и напыляется на поверхность. При этом частицы расплавляются в момент удара в напыляемую поверхность без окисления.

Испытания показали, что установка позволяет получать антикоррозионные покрытия цинком толщиной 100-300 мкм на поверхности труб с коэфициентом использования порошка 50-80\%. При этом адгезия напыленного слоя к поверхности трубы составляет 20-40 МПа. Пористость покрытия до $10 \%$ [49].

По запросу Косарева В.И. приготовлена партия порошка железистого цинка крупностью менее 45 мкм из фильтростатков. После центробежной фильтрации гартцинка из ванн цинкования Новосибирского металлургического завода, получены фильтростатки, которые измельчали в шаровой мельнице.

Получаемый порошок железистого цинка оказался пригоден для напыления и может использоваться вместо цинкового порошка. Поверхность обладает более высокой твердостью, чем цинк, что способствует повышению износостойкости.

Однако, применение порошка железистого цинка для цинкования напылением недостаточно изучено. Несмотря на то, что порошок имеет пониженную окисленность, а содержание железа в нем зависит от состава исходных отходов изменяется в широких пределах и требуют изучения влияния концентрации железа на коррозионные стойкость покрытия.

Горячее цинкование и газотермическое напыление какой-то мере взаимно дополняют друг друга и позволяют решать задачи, связанные с защитой изделий от коррозии.

Основным недостатком, удорожающим процесс, это высокий выход порошковых отходов. Отходы окисленного порошка цинка образуются (10-20\%), как отсев мелкой фракции (менее 30 мкм), образовавшихся при распылении расплавленного цинка воздухом. Второй источник отходов при использование крупной фракции в газотермическом напылении цинка на трубы и металлоконструкции. При этом значительная часть порошка (20-50\%) не прилипает к поверхности и окисляясь выносится в циклоны.

Для снижения воздействия высокого выхода отходов проведено испытание переработки порошковых отходов вмешиванием его с помощью погружного фильтра в расплав цинка.

Мелкие частицы крупностью от 10-40 микрон покрыты окисью цинка по поверхности толщиной 2-5 микрон. Даже при нагреве выше температуры плавления цинка остаются не сливающимися каплями, так как покрыты окисной пленкой. 
Полагается, что вмешивание окисленного порошка цинка в расплав цинка с покрытием из хлористого цинка при $440-470^{\circ} \mathrm{C}$ создаст условия очистки окисной пленки по реакции:

$$
\begin{gathered}
\mathrm{Zn}(\mathrm{ZnO})+\mathrm{ZnCl}_{2}+\mathrm{NH}_{4} \mathrm{Cl}=\mathrm{ZnCl}_{2}+\mathrm{H}_{2} \mathrm{O}+\mathrm{NH}_{3}+\mathrm{Zn}_{\text {}} ; \\
\mathrm{Zn}+2 \mathrm{NH}_{4} \mathrm{Cl}=\mathrm{ZnCl}_{2}+2 \mathrm{NH}_{3}+\mathrm{H}_{2} .
\end{gathered}
$$

Обычная загрузка порошка на расплав под мешалку значительная часть хлористого аммония испаряется, очищает часть порошка от окиси, оплавляется, но основная масса не смачивается и остается в виде пены на расплавленном цинке, постепенно дробится и хлорируется. Такая загрузка шихты под мешалку проходит медленно, недостаточно полно, так как образуется пена из расплавленных частиц покрытых окисной оболочкой мешающей слиянию.

Моделью для испытаний служила лабораторная центрифуга ОП 130 [40].

Центрифуга (рис. 57) содержит обогреваемый котел 1 для расплава, съемный фильтр состоящий из нижнего конуса 2 и верхнего конусного цилиндра 3, соединенных большими основаниями с образованием фильтрующей щели 4. Нижний конус 2 соединен валом 5 с приводом 6. Двигатель 6 установлен на кулисном механизме 7 для осевого вертикального перемещения вместе с тарелью 2. Зазор щели 4 вначале свободный 0,5-1 мм и в конце процесса регулируется сжатием тарели 2 с конусным цилиндром 3 пружинным фиксатором зазора 8. Нижняя тарель у оси снабжена окнами 9

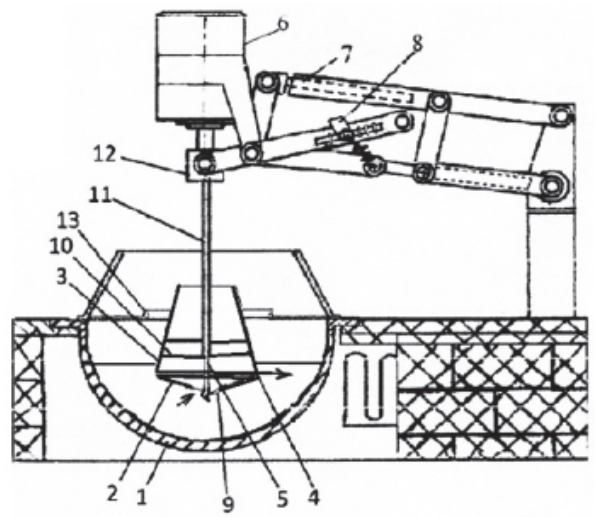

Рис. 57. Центрифуга лабораторная:

2 - нижняя тарель;3 - конусный цилиндр; 4 - фильтрующая щель; 9 - окна загрузочные для захвата расплава. Верхний конусный цилиндр крепится к трубчатому ротору 11 .

В котел загружается первичная навеска цинка на треть объема емкости котла. Цинк нагревается до температуры $450-470^{\circ} \mathrm{C}$, затем на поверхность расплава догружается слой $0,5-1$ см хлористого цинка. Зазор щели 4 устанавливается в заданном интервале 0,5-1 мм фиксатором 8. В котел с расплавом при помощи кулисного механизма 7 погружается фильтр со щелью 4 под уровень расплава и приводится во вращение. 
При вращении фильтра расплав засасывается через окна 9 в нижней тарели, омывает оплавляемую шихту и струей расплава под давлением расплава выбрасывается через щель 4. Окисная пленка на движущихся частицах реагирует с хлористым аммонием, поверхность очищается и капли сливаются с жидким цинком в ванне.

По мере накопления расплавленного цинка его разливают в слитки из под слоя флюса.

После наполнении емкости котла расплавом сжимают основания тарели и большого основания конусного цилиндра до размера 0,1 мм. Вращают фильтр в расплаве в течение

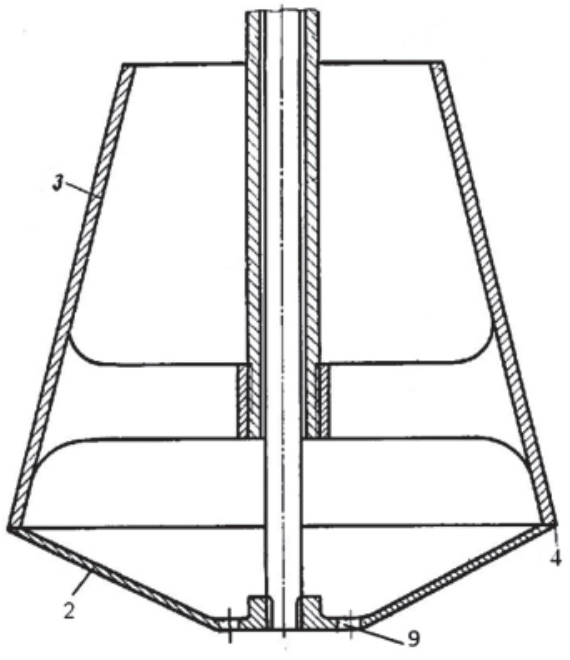

Рис. 58. Фильтр контейнерный: 2 - нижняя тарель;3 - конусный цилиндр; 4- фильтрующая щель; 9 - окна загрузочные 5-10 мин без подгрузки шихты для наполнения осадка в полости. Фильтр не прекращая вращения поднимают выше крышки и освобождают сжатие зазора щели. Под действием центробежной силы щель расширяется и осадок выбрасывается.

На заключительной стадии не прореагировавший разгруженный фильтростаток с добавкой 0,9\% хлористого аммония от веса загружают в верхний конусный цилиндр и оплавляют циркуляцией оставшегося в котле расплава и флюса.

Методика опытов. В котел загружено 20 кг цинка, который нагревают до температуры $450^{\circ} \mathrm{C}$. Цинк расплавляется и на поверхность догружается слой 0,5-1 см флюса в виде хлористого цинка. В отходы весом 5 кг окисленного порошка, содержащего $0,19 \%$ кислорода смешивают с фиксированным расходом хлористого аммония от веса порошка. Зазор щели 4 фильтра устанавливается до 0,5-1 мм ослаблением фиксатора 8. Фильтр диаметром 130 мм приводят во вращение со скоростью 360 об/мин.

После загрузки последней порции партии шихты загрузку прекращают и отфильтровывают осадок. По весу отфильтрованного фильтростатка в отношении к весу партии определяли долю оплавленного порошка, как показатель использования цинка. В табл. 31 приведены результаты опыты по оплавлению окисленного порошка. 
Таблица 31

Результаты подобных опытов оплавления порошка

\begin{tabular}{|c|c|c|c|c|}
\hline $\begin{array}{c}\text { Номер } \\
\text { опыта }\end{array}$ & Вес загрузки порошка, кг & $\begin{array}{c}\text { Расход, } \%, \\
\mathrm{NH}_{4} \mathrm{Cl}\end{array}$ & $\begin{array}{c}\text { Вес остатка, } \\
\text { г }\end{array}$ & $\begin{array}{c}\text { Процент оплав- } \\
\text { ления порошка }\end{array}$ \\
\hline 1 & 5, в ванну без слоя $\mathrm{ZnC}_{2}$ & 0,5 & 39,3 & 18,2 \\
\hline 2 & 5 & 0 & 200,0 & 8,3 \\
\hline 3 & 5 & 0,3 & 32,8 & 31,9 \\
\hline 4 & 5 & 0,5 & 29,2 & 39,3 \\
\hline 5 & 5 & 0,9 & 14,1 & 70,7 \\
\hline 6 & 5 & 1,3 & 10,5 & 78,2 \\
\hline 7 & 5, под мешалку & 0,9 & 25,5 & 47,0 \\
\hline
\end{tabular}

В опыте 1 отходы порошка с добавкой вмешивались в ванну без наплавления начального слоя хлористого цинка.

В отсутствии слоя хлористого цинка на поверхности расплавленного цинка в исходном покрытии при загрузке порошка в нагретый конусный цилиндр будет происходить дополнительное его окисление. После вовлечения такого окисленного порошка струей цинка он остается не смачиваемым и всплывет на поверхности ванны продолжая окисляться.

При вмешивании отходов на ванну без предварительного наведений слоя хлористого цинка доля оплавленного порошка составила $18,2 \%$ и перемешивание пены 200 мин.

При вмешивании порошка цинка (опыт 2) без хлористого аммония доля оплавления $8,3 \%$.

При вмешивании порошка цинка без хлористого аммония доля оплавления $8,3 \%$. В ванне расплава цинка образуется густая пена, которая перемешивалась 160 мин.

В ванне расплава цинка образуется густая пена. Приемлемое оплавление порошка достигается при расходе $0,9 \%$ хлористого аммония, при котором доля оплавления составила 70,7\%.

Повышение расхода хлористого аммония до $1,3 \%$ незначительно повышает оплавление порошка, но излишне повышает хлорирование металлического цинка.

Повышение расхода хлористого аммония незначительно повышает оплавление порошка вероятно за счет хлорирования металлического цинка (реакция 2). 
В опыте 8 вместо нижней тарели на резьбу вала поставлена лопастная мешалка для вмешивания шихты в расплав.

Доля оплавления порошка составила $47 \%$, меньше чем в предыдущих опытах.

При вращении фильтра в расплаве в полости фильтра за счет разницы центробежных сил у окон конуса и на периферии щели фильтра возникает всасывание расплава через окна и под давлением выбрасывается через щель.

После загрузки шихты в конусный цилиндр порошок увлекается циркулируюшим расплавом и суспензия порошка с расплавом под давлением выбрасывается через щель фильтра.

При этом происходит разогрев частицы порошка до температуры плавления, испарение хлористого аммония $\left(327^{\circ} \mathrm{C}\right)$ и воздействие его паров на окисную поверхность оплавленной частицы порошка.

Происходит одновременное механическим воздействие на окисную поверхность частиц порошка, циркулирующим расплавом путем продавливания через узкую щель в момент его оплавления, механическое воздействие давления прохождением через щель, химическое воздействие испаряющегося хлористого аммония с последующим очищенных капель в общую массу циркулирующего расплава. Очищенная поверхность капли цинка от окисной пленки продолжает взаимодействовать с остатками хлористого аммония.

Способ позволяет на 90,4\% оплавить порошок цинка и тем самым снизить потери цинка при переработке порошковых отходов цинка [50].

По всей вероятности повышение доли оплавления способствует воздействие циркуляции расплава на поверхность порошка частиц. Расчет центробежной силы в главе 3 показал, что условиях опыта скорость движения расплава из щели 25 дм/с. Это может воздействовать на реакцию по поверхности частиц и обеспечить интенсивное физико-химическое воздействие на порошок цинка в момент плавления для удаления окисной пленки с поверхности мелких частиц и оплавить в жидкий металл.

Переработка отходов порошка вмешиванием в расплав фильтра практически превращается в физико химический реактор взаимодействия твердой фазы с расплавом и газовой фазой. Для уточнения такого предположения требуются сравнительные исследования кинетики процесса.

В целом вмешивание отходов окисленного цинкового порошка в расплав цинка покрытом хлористым цинком и циркуляцией его через полость фильтра обеспечивает оплавление порошка цинка в течение 10 мин. 


\section{Гдава 6. СОПОСТАВ ЛЕНИЕ РЕЗУ ДЬТАТОВ ЦЕНТОБЕЖНОЙ ФИЛЬТРАЦИИ РАСПЛАВОВ МЕТА ЛДОВ И СПЛАВОВ ОТ ПРИМЕСЕЙ}

В настоящем проведено обобщение результатов испытаний центробежной фильтрации расплавов разных металлов от примесей и оценка совместного влияния свойств расплава и центробежный фактор разных центрифуг. В табл. 32 приведено сравнение результатов очистки разных металлов от твердых примесей центробежной фильтрацией.

Таблица 32

Сравнение результатов очистки разных металлов от твердых примесей центробежной фильтрацией на лабораторных и промышленных центрифугах

\begin{tabular}{|c|c|c|c|c|c|c|c|c|c|}
\hline $\begin{array}{l}\text { № } \\
\Pi / \Pi\end{array}$ & & 1 & 2 & 3 & 4 & 5 & 6 & 7 & 8 \\
\hline 1 & Рафинируемый металл & $\mathrm{Zn}$ & $\mathrm{Zn}$ & Sn & $\mathrm{Sn}$ & $\mathrm{Sn}$ & $\mathrm{Sn}$ & $\mathrm{Sn}$ & $\mathrm{Pb}$ \\
\hline 2 & Примесь элемент X & $\mathrm{Fe}$ & $\mathrm{Fe}$ & $\mathrm{Fe}$ & As & As & As & $\mathrm{Cu}$ & $\mathrm{Cu}$ \\
\hline 3 & [X] исходный & 0,27 & 2,23 & 3,53 & 2,13 & 0,42 & 0,4 & 0,5 & 0,76 \\
\hline 4 & [X] конечный & 0,06 & 0,21 & 0,14 & 0,2 & 0,1 & 0,01 & 0,006 & 0,08 \\
\hline 5 & Твердое соединение & $\mathrm{FeZn}_{7}$ & $\mathrm{FeA}_{13}$ & $\mathrm{FeSn}_{2}$ & FeAs & FeAs & MnAs & $\mathrm{Cu}_{2} \mathrm{~S}$ & $\mathrm{Cu}_{2} \mathrm{~S}$ \\
\hline 6 & $T,{ }^{\circ} \mathrm{C}$, фильтрации & 450 & 513 & 520 & 350 & 450 & 350 & 300 & 400 \\
\hline 7 & Диаметр фильтра & 110 & 650 & 650 & 450 & 450 & 650 & 100 & 650 \\
\hline 8 & Разница плотностей & 1,18 & 1,22 & 0,42 & 0,85 & 0,85 & 0,8 & 0,22 & 3,49 \\
\hline 9 & $\Phi_{\mathrm{o}}=R \cdot \omega^{2} / g=$ Цен. факт. & 0,81 & 0,52 & 0,5 & 0,58 & 0,58 & 0,52 & 0,88 & 0,52 \\
\hline 10 & Выход дроссов, \% & 12,6 & 27,4 & 39,2 & 15 & 2,84 & 5,9 & 10,3 & 6,2 \\
\hline 11 & $\begin{array}{l}\text { Степень удаления } \\
\text { примесей, \% }\end{array}$ & 93,2 & 76,0 & 97,6 & 92 & 82,9 & 97,5 & 98,9 & 64,4 \\
\hline 12 & Выход металла в отходы & 11 & 27,4 & 9,1 & 1,84 & 2,54 & 13,4 & 17,9 & 9,4 \\
\hline 13 & $K_{\text {pспр }} X=\left[X_{\text {дрос }}\right] /\left[X_{\text {pacn }}\right]$ & 87,8 & 36,1 & 62,8 & 65,4 & 119 & 661 & 800 & 99 \\
\hline 14 & Источник публикации & $\begin{array}{c}40] \\
\text { П. } 5.8 \\
\text { т. } 1.4 \\
\end{array}$ & $\begin{array}{c}{[40]} \\
\text { T. } 12.5\end{array}$ & $\begin{array}{l}{[1]} \\
\text { т. } 1.2\end{array}$ & $\begin{array}{l}{[1]} \\
\text { т. } 1.9\end{array}$ & \begin{tabular}{|c|}
{$[40]$} \\
т. 1.10
\end{tabular} & $\begin{array}{l}{[40]} \\
\text { т. } 23\end{array}$ & $\begin{array}{c}{[40]} \\
\text { т. } 1.25 \text {. }\end{array}$ & $\begin{array}{c}{[1]} \\
\text { рис. } 1.9\end{array}$ \\
\hline
\end{tabular}


Глава 5

Продолжение табл. 32

\begin{tabular}{|c|c|c|c|c|c|c|c|c|c|}
\hline $\begin{array}{l}\text { № } \\
\text { П/П }\end{array}$ & & 9 & 10 & 11 & 12 & 13 & 14 & 15 & 16 \\
\hline 15 & $\begin{array}{l}\text { Рафинируемый } \\
\text { металл }\end{array}$ & $\mathrm{Pb}$ & $\mathrm{Pb}$ & $\mathrm{Pb}$ & $\mathrm{Pb}$ & $\mathrm{Pb}$ & $\mathrm{Pb}$ & $\mathrm{Pb}$ & $\mathrm{Pb}$ \\
\hline 16 & Примесь элемент X & $\mathrm{Cu}$ & $\mathrm{Cu}$ & As & As & $\mathrm{Sn}$ & $\mathrm{Sb}$ & $\mathrm{Bi}$ & $\mathrm{Ag}$ \\
\hline 17 & [X] исходный & 2,7 & 0,27 & 1,3 & 0,2 & 0,15 & 0,3 & 1 & 1,2 \\
\hline 18 & [X] конечный & 0,24 & 0,0025 & 0,39 & 0,007 & 0,006 & 0,007 & 0,35 & 0,9 \\
\hline 19 & Твердое соединение & $\begin{array}{l}\underbrace{n} \\
\frac{n}{2} \\
+ \\
\tilde{D}^{-} \\
\tilde{J}^{-}\end{array}$ & $\tilde{J}^{n}$ & $\underbrace{m}_{n}$ & $\begin{array}{l}0^{+} \\
\text {离 } \\
\text { L }\end{array}$ & $\begin{array}{l}\stackrel{\Xi}{U}^{m} \\
\underset{\tilde{U}}{\tilde{U}}\end{array}$ & $\begin{array}{l}\overbrace{}^{\sigma} \\
\underbrace{\tilde{E}}_{\tilde{0}}\end{array}$ & $\begin{array}{l}\sum_{\tilde{U}}^{N} \\
\sum_{\tilde{U}}^{\infty}\end{array}$ & $\stackrel{\text { N }}{\mathfrak{o n}^{n}}$ \\
\hline 20 & $T,{ }^{\circ} \mathrm{C}$ фильтрации & 400 & 340 & 500 & 350 & 350 & 350 & 480 & 480 \\
\hline 21 & Диаметр фильтра & 110 & 110 & 110 & 200 & 200 & 200 & 650 & 650 \\
\hline 22 & Разница плотностей & 2,89 & 3,49 & 8,0 & 7,51 & 4,65 & 4,39 & 2,29 & 1,49 \\
\hline 23 & $\Phi_{\mathrm{o}}=R \cdot \omega^{2} / g$ фактор & 0,81 & 0,81 & 0,96 & 1,47 & 1,47 & 1,47 & 0,52 & 0,52 \\
\hline 24 & Выход дроссов, \% & 8,5 & 3,42 & 5,7 & 1,92 & 1,92 & 1,92 & 4,5 & 2,1 \\
\hline 25 & $\begin{array}{l}\text { Процент удаления } \\
\text { примеси }\end{array}$ & 91 & 91,2 & 88,2 & 96,5 & 96 & 97,7 & 33,4 & 26,3 \\
\hline 26 & $\begin{array}{l}\text { Выход металла в от- } \\
\text { ходы }\end{array}$ & 1,33 & 9,8 & 2,5 & 0,71 & 1,60 & 0,57 & 5,5 & 3,5 \\
\hline 27 & $K_{\text {pспр }} X=\left[X_{\text {дрос }}\right] /\left[X_{\text {paсп }}\right]$ & 120 & 3280 & 41 & 3443 & 1767 & 4229 & 42 & 16 \\
\hline 28 & $\begin{array}{l}\text { Источник публика- } \\
\text { ции }\end{array}$ & \begin{tabular}{|c|}
{$[1]$} \\
т. 2.2
\end{tabular} & $\begin{array}{c}{[1]} \\
\text { т. } 8.2\end{array}$ & $\begin{array}{c}{[1]} \\
\text { т. } 5.2\end{array}$ & $\begin{array}{l}{[1]} \\
\text { т. } 615.2\end{array}$ & $\begin{array}{c}{[1]} \\
\text { п. } 2.3 .\end{array}$ & $\begin{array}{c}{[1]} \\
\text { c. } 110\end{array}$ & $\begin{array}{c}{[1]} \\
\text { гл. } 5.2\end{array}$ & $\begin{array}{c}{[1]} \\
\text { гл. } 4.2\end{array}$ \\
\hline
\end{tabular}


Окончание табл. 32

\begin{tabular}{|c|c|c|c|c|c|c|c|c|}
\hline $\begin{array}{l}\text { № } \\
\text { п/п }\end{array}$ & & 17 & 18 & 19 & 20 & 21 & & \\
\hline 29 & Рафинируемый металл & $\mathrm{Al}$ & $\mathrm{AlSi}$ & $\mathrm{AlCu}$ & In & $\mathrm{Ga}$ & & \\
\hline 30 & Примесь элемент X & $\mathrm{Fe}$ & $\mathrm{Fe}$ & $\mathrm{Fe}$ & $\mathrm{Ni}$ & As & & \\
\hline 31 & [X] исходный & 5,35 & 3,8 & 10 & 5 & 18,6 & & \\
\hline 32 & [X] конечный & 0,9 & 0,6 & 1,3 & 0,1 & 0,1 & & \\
\hline 33 & Твердое соединение & $\mathrm{FeA}_{13}$ & $\mathrm{FeA}_{13}$ & $\mathrm{FeA}_{13}$ & $\mathrm{In}_{3} \mathrm{Ni}_{2}$ & $\mathrm{AsGa}$ & & \\
\hline 34 & $T,{ }^{\circ} \mathrm{C}$ фильтрации & 680 & 590 & 650 & 170 & 30 & & \\
\hline 35 & Диаметр фильтра & 110 & 650 & 650 & 110 & 110 & корел & корел \\
\hline 36 & Разница плотностей & 4,81 & 2,43 & 2,43 & 5,25 & 5,81 & 1 & \\
\hline 37 & $\Phi_{\mathrm{o}}=R \cdot \omega^{2} / g$ фактор & 1,51 & 3,50 & 3,5 & 1,0 & 0,241 & & 1 \\
\hline 38 & Выход дроссов, \% & 19,6 & 25,7 & 42 & 11,4 & 63,7 & $-0,04$ & 0,18 \\
\hline 39 & $\begin{array}{l}\text { Процент удаления при- } \\
\text { меси }\end{array}$ & 84 & 88,7 & 92,8 & 98,6 & 99,6 & 0,19 & 0,22 \\
\hline 40 & Выход металла в отходы & 3,35 & 5,1 & 2,4 & 0,6 & 2,2 & $-0,52$ & $-0,26$ \\
\hline 41 & $K_{\mathrm{pcrp}} X=\left[X_{\text {дpoc }}\right] /\left[X_{\mathrm{pacn}}\right]$ & 26 & 22 & 17 & 598 & 290 & 0,38 & 0,08 \\
\hline 42 & Источник публикации & $\begin{array}{l}{[40]} \\
\text { т. } 21\end{array}$ & $\begin{array}{l}{[40]} \\
\text { т. } 24\end{array}$ & $\begin{array}{l}{[40]} \\
\text { т. } 25\end{array}$ & $\begin{array}{l}{[40]} \\
\text { т. } 17\end{array}$ & $\begin{array}{l}{[40]} \\
\text { T. } 26\end{array}$ & & \\
\hline
\end{tabular}

В качестве основного показателя взята разность плотностей соединений примесей и жидкого металла от которого зависит эффект разделения твердых кристаллов от жидкого металла.

Коэффициент распределения примеси «X» определялся как отношение концентрации примеси $X$ в отходах к концентрации примеси в рафинированном металле по уравнению:

$$
K_{\text {pспр }} X=\left[X_{\text {дрос }}\right] /\left[X_{\text {paсп }}\right] .
$$

Оценено взаимное влияние разности плотностей твердых примесей и жидкого металла на выход металла в отходы на единицу удаленной примеси с корреляцией $K=-0,52$ и коэффициент распределения примеси между дроссом и очищенным металлом с корреляцией $K=0,38$. 
Основным показателем сравнения центрифуг принят центробежный фактор на отжиме, зависящий диаметра фильтра центрифуг и скорости его вращения:

$$
\Phi_{\mathrm{o}}=\frac{R \cdot n^{2}}{900}
$$

где $R$ - радиус фильтра (м); $n$ - скорость вращения $\left(\mathrm{c}^{-1}\right)$.

Центробежный фактор влияет на выход металла в отходы дроссов с $K=-0,26$ и на степень удаления примесей с $K=0,22$.

Степень корреляционной зависимости невелика, но и массив фильтруемых сред значительно разнородный и масштаб оборудования также значительно различается.

Лабораторные модели центрифуг оснащены приводом с изменяющимися скоростями вращения фильтра и съемными фильтрами и развивались с целью улучшению удобств проведения опытов. Причем, модели изменялись под задание из имеющихся узлов и более существенно изменялись по желанию заказчиком - фирм с малым объемов производства. В табл. 33 приведены характеристика основных моделей лабораторных центифуг.

Таблица 33

Характеристика основных моделей лабораторных центифуг

\begin{tabular}{|l|c|c|c|c|c|}
\hline \multicolumn{2}{|c|}{ Параметр/модель } & Оп110 & ЦП130 & ЦП100с & ЦП80 \\
\hline Диаметр тарелей & мм & 110 & $100-130$ & 100 & $80-60$ \\
\hline Число оборот в распл & об/мин & $150-600$ & $150-600$ & 300 & $150-600$ \\
\hline Число оборот отжим & об/мин & $500-1500$ & $500-1500$ & 300 & $500-1500$ \\
\hline Температура фильтрации & ${ }^{\circ} \mathrm{C}$ & $200-600$ & $200-600$ & $200-600$ & $20-1300$ \\
\hline Источник, рис & $\begin{array}{c}{[1]-} \\
\text { рис. } 1.5\end{array}$ & $\begin{array}{c}{[1]-} \\
\text { pис. } 1.11\end{array}$ & $\begin{array}{c}{[1]-} \\
\text { pис. } 1.39\end{array}$ & $\begin{array}{c}{[40]-} \\
\text { pис. } 31\end{array}$ \\
\hline
\end{tabular}

Лабораторные модели снабжена двигателями постоянного тока и сменными тарелями.

Модель ЦП100с в последней модификации в упрощенном виде, предназначена для малых предприятий и снабжена сменными шкивами.

Модель ЦП-80 со сменными фильтрами из стали, графита, фторопласта и использовалась для фильтрации галлия, фильтрации меди от никеля.

Приведено сравнение характеристики базовой промышленной модели центрифуги ПАФВС-650 с другими вариантами моделей. Последующие модели изменялись в соответствии с опытом эксплуатации 
базовой модели, требований изготовителей и пожеланием перспективных заказчиков малых предприятий по снижению веса центрифуг и габаритов. Более трудной задачей было распространение центрифуг для свинцовых заводов, в сотни раз большими объемами производства. Поэтому СКБ ГИТ СО РАН разработали для УКСЦК центрифугу ПАФВС-1200-2 с диаметром фильтра 1200 мм. Тем не менее Австралийская фирма с непрерывным циклом рафинирования свинца приобрела пять центрифуг модели ПАФВС-650. Характеристика промышленных центрифуг приведена в табл. 34 .

Таблица 34 Сравнение характеристик промышленных центрифуг с погружным фильтром

\begin{tabular}{|c|c|c|c|c|c|c|}
\hline \multicolumn{2}{|c|}{ Параметр/модель } & ПАФВС-650-9 & ЦП200 & ЦП300 & ЦП500 & ПАФВС-1200 \\
\hline Диаметр тарелей & MM & 650 & 200 & 300 & 500 & 1200 \\
\hline $\begin{array}{l}\text { Число оборот } \\
\text { в расплаве }\end{array}$ & \multirow{2}{*}{ об/мин } & 280 & $200-300$ & 250 & 275 & 180 \\
\hline $\begin{array}{l}\text { Число оборот } \\
\text { в отжиме }\end{array}$ & & 365 & $1000-1500$ & 600 & 465 & 360 \\
\hline Габариты,длина & MM & 3530 & 830 & 1100 & 2000 & 3100 \\
\hline Ширина & MM & 1900 & 820 & 770 & 1500 & 2200 \\
\hline Высота & MM & 2975 & 1300 & 1200 & 1500 & 1800 \\
\hline Macca & $\mathrm{K \Gamma}$ & 6000 & 300 & 800 & 800 & 9800 \\
\hline Мощность & KBT & 46 & 3 & 3 & 15 & 85 \\
\hline Диаметр котла & MM & $1500-2500$ & $400-600$ & $800-1100$ & $800-1500$ & $2800-3200$ \\
\hline \multicolumn{2}{|l|}{ Источник, рис. } & [99] рис. 1.9 & $\begin{array}{c}\text { [99] } \\
\text { рис. } 2.9\end{array}$ & $\begin{array}{c}\text { [94] } \\
\text { рис. } 7\end{array}$ & $\begin{array}{c}\text { [94] } \\
\text { рис. } 8\end{array}$ & \\
\hline \multicolumn{2}{|l|}{ Разработчик } & $\begin{array}{c}\text { СКБ ГИТ } \\
\text { СО РАН, } \\
\text { завод Труд }\end{array}$ & $\begin{array}{l}\text { СКБ } \\
\text { ГИТ }\end{array}$ & HOK & HOK & СКБ ГИТ \\
\hline \multicolumn{2}{|c|}{ Использовано, испытано } & HOK & Япония & Орел & Италия & УКСЦК \\
\hline
\end{tabular}

Базовая модель ПАФВС-650, разработанная СКБ ГИТ СО РАН, освоенная в изготовлении механическим заводом «Труд», принята в эксплуатацию на Новосибирском оловянном комбинате, Рязанском заводе цветных металлов, Магнитогорском металлургическом комбинате. Испытана на зарубежных заводах Чехии, ГДР. Приобретены по лицензии в Австралию, Боливию, Мексику. 


\section{ПИТЕРАТУРА}

1. Дьяков В.Е. Центробежная фильтрация расплавленного олова и свинца: монография. - М.: Издательский дом Академии Естество знания, ISBN 978-5-91327-574-5; DOI 10.17513/np.347; 2019; 140 с.

2. Проскурин Е.В. Цинкование / Е.В. Проскурин, В.А. Попович, A.T. Мороз. - M, 1988, $256 \mathrm{c.}$

3. А.с. СССР № 463334 Аппарат для рафинирования расплавленных металлов от нерастворимых примесей / Сутурин С.Н., Бауэр Е.Т., Семенов А.Е., Дьяков В.Е., Деев С.Л., Перкис Л.В., Коновалов Л.В., Войцеховский Б.В., Долгов Л.В., Новосибирский оловозавод; Институт гидродинамики СО АН СССР - заявл № 1374168 от 4.11.69; МПК4 С22b9/02. // Оф. бюл. «Открытия, изобретения». М., Опубл. 25.06.77, Би № 23 с201.

4. Дьяков В.Е «Образование пены при фильтрации расплава гартцинка» // Евразийский союз ученых, Технические науки, XX Международной конференции «Современные концепции научных исследований», М., Изд: ООО «Международный Образовательный Центр» (Москва), ISSN 2411-6467, 2015, № 11 (20). ч. 3. С. 58-62.

5. Дьяков В.Е. Кристаллизация расплава при центробежной фильтрации гартцинка // ж. Цветные металлы, Издат дом «Руда и металлы». M., 2016. № 6 (882) C. 43-50. DOI 10.17580/tsm.2016.06.05

6. Дьяков В.Е. Кинетика центробежной фильтрации расплавленного гартцинка погружным фильтром // Технология металлов, Изд-во Наука и технологии ООО. М., 2011. № 6. С. 32-37.

7. Свойства элементов, Справочник т. 1, под ред М.Е. Дрица. М.: Металлургия, 1997, 432 с.

8. Справочник химика. т. 5. М.: Химия, 1964, 971 с.

9. Стренк Ф. Перемешивание и аппараты с мешалкой, пер. с польск. Л., 1975.

10. Павлов К.Ф., Романков П.Г., Носков А.А. Примеры и задачи по курсу процессов и аппаратов химической технологии. Альянс, 2013. $576 \mathrm{c}$. 
11. Поведение кристаллов примесей олова в центробежном поле»// Научный альманах, Консалт комп Юком (DOI:10.17117/ na.2016.11.02.107), 2016, № 11 2(25), C. 107-115.

12. Калабушкин В.С., Пикунов М.В.-Фильтрация металла // Металлургия и технология цветных металлов: сб.науч. тр. № 33, 1960. 230 с.

13. Стуров Г.Е., Долгов А.В., Кремзер Ф.Г. О моделировании погружных центрифуг// Механика быстропротекающих процессов, вып. 51, 1981, C. 184189.

14. Пат 1839641 РФ. Способ управления фильтрующей центрифугой в процессе рафинирования расплавленных металлов от твердых примесей // Токарев Г.И., Дьяков В.Е., Клещенко И.Н., Дугельный А.П., Корюков Ю.С., Новосибирский оловянный комбинат МПК6 В04 b11/02 заяв № 4859332; от.23.06.90; Опуб 30.12.93, Би№ 48. С. 141.

15. Пат 2033275 РФ, Центрифуга для разделения суспензий / Дьяков В.Е., Корюков Ю.С., Дугельный А.П., Новосибирский оловянный комбинат МПК6 В04 b3/04; заяв. № 4905263от 25.01.91, Опуб. 20.04.95, Би № 11 с. 130.

16. Дьяков В.Е. Физические основы центробежной фильтрации расплавов отходов цветных металлов погружаемым фильтром // Научный альманах, Технические науки. Тамбов: Изд-во ООО «Консалт комп Юком» (ISSN 2411-7609), 2019. № 42 (54), С. 32-41.

17. Хансен М. Андерко К. Структуры двойных сплавов. М.: Металлургиздат, 1962. т. 2. 1487 с.

18. Schmitz D., Friedrich B. In-house recycling of hard zinc and zinc ash by liquid metal centrifugation // IME Process Metallurgy and Metal Recycling; Proceedings of EMC 2007, Р. 1-20; Труды ЕMC 2007, C. 1-20.

19. Диаграммы состояния металлических систем: сборник. М., 1970. вып. 16. С. 130.

20. Тюрин А.Г. Расчетные энтальпии и энтропии образования интерметаллических соединений // Электрохимия. 1990. Т. 26, вып. 12. C. $1599-1606$.

21. Могутнов Б.М., Томилин И.А., Шварцман Л.А. Термодинамика сплавов железа. М.: Металлургия, 1984. С. 208.

22. Трусов Б.Г. Програмная система TERRA для моделирования фазовых и химических равновесий // Труды XIV Межд. конф. по хим. термодин. СПб., 2002. 
23. Дьяков В.Е. Кристаллизация расплава при центробежной фильтрации гартцинка // Цветные металлы. М.: Изд: Издательский дом «Руда и металлы». 2016. № 6 (882) C. 4350; DOI: 10.17580/tsm.2016.06.05.

24. Дьяков В.Е. Снижение потерь цинка при переработке расплава гартцинка фильтрацией // Современные тенденции развития науки и техники: сб. н. т. по материал VII межд. науч. практ. конф., изд. АПНИ, Белгород, ISSN: 2413-0869; 2015. № 7. ч. 3, С. 5359.

25. Миркин Л.И. Справочник по рентгеноструктурному анализу поликристаллов. М., 1961. 350 с.

26. Варнек В.А., Мазалов Л.Н., Перевозкин В.Ю., Дьяков В.Е. Отчет НИР «Исследования фазовых форм железа в полупродуктах рафинирования», № 519-076, НОК, ИНХ СО РАН, 1992.

27. Дьяков В.Е. Исследование фазового состава продуктов фильтрации цинка с ванн цинкования // Межд. науч. иссл. журн. Екатеринбург, ISSN: 2303-9868; 2015, № 5 (36), ч. 2, С. 5152.

28. Тарасов А.В., Рабичева Л.М., Минаева Н.М., Шнайдер И.Ф., Романов Л.А. Опытно-промышленные испытания ликвационно-химического рафинирования электротермического цинка нам Беловском цинковом заводе // Бюллетень «Цветная металлургия», 1978, № 9, С. 3132.

29. Смирнов А.В. Горячее цинкование, М., 1953. 139 с.

30. Дьяков В.Е Разработка технологии очистки гартцинка ванн горячего цинкования // Сталь. 2002, № 4, С. 6870.

31. Дьяков В.Е. Снижение потерь цинка при переработке расплава гартцинка фильтрацией // Современные тенденции развития науки и техники: сб н. т. по матер. VII межд науч практ. конф., Изд: АПНИ, ISSN: 2413-0869; (Белгород), 2015. № 7, ч. 3, С. 5359.

32. Патент 1005480 РФ, Способ рафинирования цинка // Дьяков В.Е., Сутурин С.Н., Новосибирский ордена Ленина оловянный комбинат - МПК6 С22b19/32. заяв. № 3321065;от 20.07.1981; Опубл.10.03.2012, Би№ 7. С. 200.

33. Патент 1839641 РФ, Способ управления фильтрующей центрифугой в процессе рафинирования расплавленных металлов от твердых примесей / Токарев Г.И., Дьяков В.Е., Клещенко И.Н., Дугельный А.П., Корюков Ю.С. Новосибирский оловянный комбинат - МПК6 В04 b11/02, заявка № 4859332; от.23.06.90, Опуб/ 30.12.93, Би№ 48. С. 141. 
34. Экстракционная очистка расплава гартцинка центробежной фильтрацией Дьяков В.Е. // «Научный альманах», Изд: ООО «Консалтинговая компания Юком» (Тамбов) 2015, № 7(9), С. 644-649, DOI: 10.17117/na.2015.07.269 - DOI 10.17117/na2015.07.644.

35. Патент 2057816 РФ, заяв. № 93001455 от 11.01.9 Устройство для рафинирования расплавленных металлов / Дьяков В.Е., Далбеев Г.В // МПК6 С22b 9/02; Опубл. 10.04.1996, Би№ 10 c205.

36. Патент № 1839639 РФ, Устройство для разделения суспензий / Дьяков В.Е., Дугельный А.П., Новосибирский оловянный комбинат // МПК5 В04b3/00; заяв. №4855828;от 31.07.90; Опубл. 30.12.93. Би№ 48. С. 50.

37. А.с. № 1777362 СССР. Центрифуга для очистки ванны расплава // Дьяков В.Е., Дугельный А.П., Корюков Ю.С., Новосибирский оловянный комбинат - заявл № 4913332; от. 21.02.91; МПК5 С22b 9/02; Опубл.10.07.12, Би№ 19; С. 508.

38. Пат 2002832 РФ. Центрифуга очистки расплава в ванне // Дьяков В.Е., заявл.№ 5015287; от .2.12.91; МПК5 С22b 9/02; опубл. 15.11.93. Би № 41. С. 14.

39. Пат 2032753 РФ. Центрифуга для очистки расплава в ванне. / Дьяков В.Е. Заявл. № 5041392; от 12.03.92; МПК5 С22b 9/02; Опубл. 10.04.95, Би № 10 С. 170.

40. Дьяков В.Е. Регенерация цветных металлов из отходов центробежной фильтрацией: монография. М.: БИБЛИО-ГЛОБУС, DOI: 10.18334/9785604067376; 2018. 116 c.

41. URL: https://ecm-zink.ru/info/stati/gazotermicheskoe-napyileniemetallizacziya.html.

42. Газотермическое напыление // под общ. ред. Л.Х. Балдаева. М., 2007. $344 \mathrm{c}$.

43. Патент 1110036 SU Дьяков В.Е., Несмелов В.Н., Галкин Е.А., Соловьев Б.А., Корюков Ю.С, Коновалов Л.В. Берляков В.Н. Лысов В.И. Устройство для получения порошка распылением легких металлов; заяв. № 3541793 от 21.01.83. МПК В22F9/08; опуб. 7.06.86; Би 21-86. С. 257.

44. Патент РФ 1489854. Аппарат сепарации металлического порошка; Дьяков В.Е., Токарев В.С., Корюков Ю.С., Галкин Е.А. и Новопашин А.И. Заяв № 4286500; от 17.7.87; МПК В07В4/08; опубл. 30.06.89; БИ24-89. С. 56. 
45. Дьяков В.Е., Соловьев Б.А. Получение порошков припоев //сб. Радиопромышленность, 1992, № 6, С. 7-8.]

46. Каичев В.В., Дьяков В.Е. Исследование порошков для бессвинцовистой пасты высокотемпературной пайки медных сплавов // Химия в интересах устойчивого развития, ISSN 0869-8538, 2006, т. 14, № 2; С. 141146.

47. Дьяков В.Е., Теренин В.И. Разработка центробежной регенерации гартцинка с получением порошка железистого цинка // Сб. тр. Научно-практическая конференция «Современные технологии, материалы и изделия порошковой металлургии», на 3 международной выставке «Металлургия 20002», Ростов Дон, 2002, С. 4748.

48. Патент РФ № 2010619 / Алхимов А.П., Косарев В.Ф., ПопЫрин А.Н. Устройство нанесения покрытия, БИ № 7, 1994.

49. Алхимов А.П., Клинков С.В., Косарев В.Ф., Фомин В.М. Холодное газодинамическое напыление. Теория и практика. Н.: Наука, 2006. $420 \mathrm{c}$.

50. Дьяков В.Е. Переработка отходов порошка цинка центробежной фильтрацией // Научный альманах. Тамбов: Изд: ООО «Консалтинговая компания Юком», 2019. № 7-1(57). С. 129-135. 


\section{ОГЛАВЛЕНИЕ}

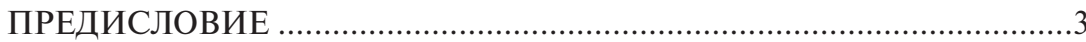

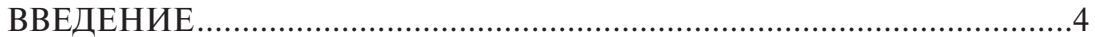

ГЛава 1. МЕТОДИКА ИССЛЕДОВАНИЯ ЦЕНТРОБЕЖНОЙ ФИЛЬТРАЦИИ РАСПЛАВОВ ПОГРУЖАЕМЫМ ФИЛЬТРОМ ..................................................................................

ГЛава 2. ФИЗИЧЕСКИЕ ОСНОВЫ ЦЕНТРОБЕЖНОЙ ФИЛЬТРАЦИИ ПОГРУЖАЕМЫМ ФИЛЬТРОМ ...................10

2.1. Поведение вращающегося фильтра в расплаве........................11

2.2. Создание эффекта всасывания расплава

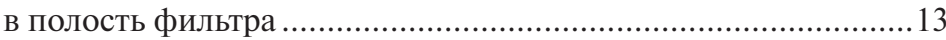

2.3. Поведение твердой частицы в поле центробежных сил в расплаве полости фильтра ...........15

2.4. Отделение жидкого цинка из пор твердого осадка под воздействием центробежной силы....

2.5. О моделировании центрифуг фильтрации расплавов погружаемым фильтром .......................................................20

ГЛава 3. ТЕХНОЛОГИЧЕСКИЕ ОСНОВЫ ЦЕНТРОБЕЖНОЙ ФИЛЬТРАЦИИ ПОГРУЖАЕМЫМ ФИЛЬТРОМ ..................22

3.1. Кинетика наполнения полости фильтра при фильтрации ......22

3.2. Влияние частоты вращения на скорость наполнения полости фильтра осадком...................30

3.3. Влияние глубины погружения окон фильтра на скорость наполнения фильтра твердой фазой.......................31

3.4. Влияние частоты вращения фильтра над расплавом на степень очистки твердого от расплава ................................33

Глава 4. ФИЗИКО-ХИМИЧЕСКИЕ ИССЛЕДОВАНИЯ ФАЗ ФИЛЬТРОСТАТКОВ

4.1. Диаграмма состояния и термодинамика преобразования фаз 
4.2. Толщина пленки жидкого цинка на поверхности твердых

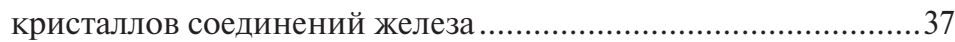

4.3. Исследование фазового состава продуктов фильтрации

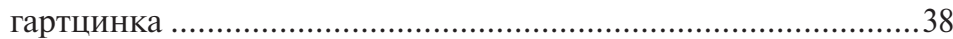

4.4. Изменение фаз после кристаллизации расплава .....................43

4.5. Распределение элементов по поверхности

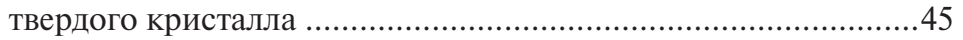

4.6. Окисленность кристаллов ……................................................48

4.7. Распределение размеров частиц соединений в дроссах фильтра..................................................................50

ГЛава 5. ТЕХНОЛОГИЯ ЦЕНТРОБЕЖНОЙ ФИЛЬТРАЦИИ ЖЕЛЕЗИСТОГО ЦИНКА.....................................................53

5.1. Кинетика удаления железа из гартцинка ...............................55

5.2. Влияние температуры расплава при фильтрации ....................59

5.3. Укрупнение частиц кристаллизацией.....................................62

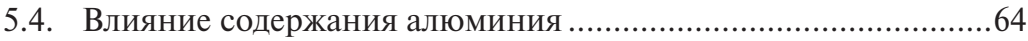

5.5. Образование пены при центробежной фильтрации .................66

5.6. Экстракция железа с алюминием из гартцинка ......................69

5.7. Фильтрации гартцинка в слое алюминиевой пены...................73

5.8. Промышленные испытание центробежной регенерации цинка из гартцинка ............................................74

5.9. Обзор вариантов очистки расплава ванны центробежной фильтрацией....................................................78

5.10. Переработка окисленного порошка цинка

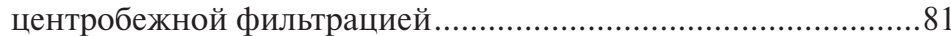

ГЛава 6. СОПОСТАВЛЕНИЕ РЕЗУЛЬТАТОВ ЦЕНТОБЕЖНОЙ ФИЛЬТРАЦИИ РАСПЛАВОВ МЕТАЛЛОВ И СПЛАВОВ

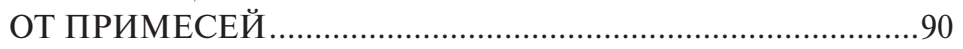

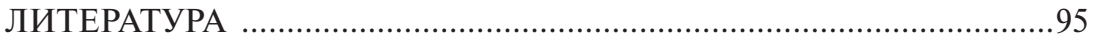


Научное издание

Дьяков Виталий Евгеньевич

\section{ОСНОВЫ ЦЕНТРОБЕЖНОЙ ФИЛЬТРАЦИИ РАСПЛАВОВ ОТХОДОВ ЦИНКА ПОГРУЖАЕМЫМ ФИЛЬТРОМ}

Монография

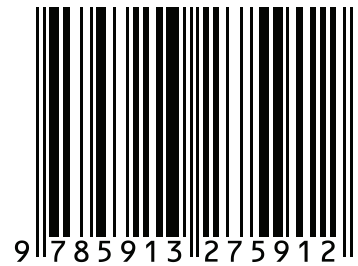

Технический редактор Кулакова Г.А.

Подписано в печать 22.08.2019

Бумага офсетная.

Гарнитура NewtonC

Формат $60 \times 841 / 16$

Печать трафаретная. Печ. л. 6,38.

Тираж 500 экз. Заказ № 021-19.

Отпечатано в типографии ИД «Академия Естествознания», 440026, г. Пенза, ул. Лермонтова, 3 